\title{
何D

\section{From Vision to Learning: Effectiveness Measures of Christian School Boards}

Ryan G. Zonnefeld

Dordt College, ryan.zonnefeld@dordt.edu

Follow this and additional works at: https://digitalcollections.dordt.edu/faculty_work

Part of the Christianity Commons, and the Educational Administration and Supervision Commons

\section{Recommended Citation}

Zonnefeld, R. G. (2009). From Vision to Learning: Effectiveness Measures of Christian School Boards. Retrieved from https://digitalcollections.dordt.edu/faculty_work/131

This Dissertation is brought to you for free and open access by Dordt Digital Collections. It has been accepted for inclusion in Faculty Work Comprehensive List by an authorized administrator of Dordt Digital Collections. For more information, please contact ingrid.mulder@dordt.edu. 


\title{
From Vision to Learning: Effectiveness Measures of Christian School Boards
}

\begin{abstract}
This exploratory study investigated the effectiveness of Christian School boards, as perceived by its members, and examined patterns and characteristics that describe internal board activities. The study employed a quantitative survey research design that revealed areas of strength and areas of growth for Christian School board operations. Board effectiveness was measured in accordance with Smoley's (1999) Model for Effective School Boards.
\end{abstract}

The research focused on four questions: (a) What are the background characteristics of Christian School board members? (b) What patterns exist in the Christian School board effectiveness ratings of school board members, presidents, and school administrators? (c) Are there mean differences between the ratings of Christian School board members, presidents, and school administrators? and (d) What are some of the factors (e.g. role on the board, school characteristics, and board member characteristics) that predict school board effectiveness ratings?

Data were collected through an online survey of 37 Christian School boards in lowa, Minnesota, South Dakota, and Wisconsin. The survey was completed by 217 school board members, school board presidents, and school administrators.

The analysis of the demographic data revealed that Christian School boards are primarily comprised of well-educated, White, middle-aged men from business and/or professional backgrounds. Internal school board activities data revealed that Christian School boards perceive themselves to be highly effective at making rational decisions and moderately effective at connecting to the community. The data also revealed that, when compared to Smoley's (1999) Model for School Board Effectiveness, Christian School board self-perceptions fell short in the areas of functioning as a group, exercising authority, working toward board improvement, and acting strategically. The difference was particularly pronounced in the area of working toward board improvement.

The research findings suggest implications for the work of Christian School boards, namely the vociferous need to diligently examine internal board activities and their effect on external outcomes. Future studies should center on the demographic representation on the board and the benefits of professional development directed to the school board itself. Attention to these implications and recommendations will contribute to strengthening the internal work of the Christian School board and, ultimately, student achievement.

\section{Keywords}

Christian education, school boards, Model for Effective School Boards

\section{Disciplines}

Christianity | Educational Administration and Supervision

\section{Comments}

- A dissertation submitted to the graduate faculty of lowa State University in partial fulfillment for the degree of DOCTOR OF PHILOSOPHY

- Dr. Joanne M. Marshall, Committee Chairperson

- (C) 2009 Ryan G. Zonnefeld 


\section{Creative Commons License}

\section{(c) $($ ) $\Theta(\theta$}

This work is licensed under a Creative Commons Attribution-NonCommercial-No Derivative Works 4.0 International License. 
From vision to learning: Effectiveness measures of Christian school boards

by

\title{
Ryan G. Zonnefeld
}

\author{
A dissertation submitted to the graduate faculty \\ in partial fulfillment of the requirements for the degree of \\ DOCTOR OF PHILOSOPHY
}

\author{
Major: Education (Educational Leadership) \\ Program of Study Committee: \\ Joanne M. Marshall, Major Professor \\ Jan Westerman-Beatty \\ Mike Book \\ Larry H. Ebbers \\ James R. Scharff
}

Iowa State University

Ames, Iowa

2009

Copyright (C Ryan G. Zonnefeld, 2009. All rights reserved. 


\section{Dedication}

To my wife, Valorie,

my partner in education,

whose unconditional love, patience, and insight

made this journey possible.

To my children,

Caden, Jocelyn, and Cambri,

whose smiles, hugs, kisses, and prayers

fill each day with joy.

To my father,

whose passion for Christian Education

is a daily inspiration.

To Christian Schools,

who model and shape God's image-bearers

in the light of scripture and creation. 
Table of Contents

List of Tables

Abstract

viii

Chapter One: Introduction

Background to the Study

Statement of the Problem $\quad 2$

Purpose of the Study $\quad 5$

$\begin{array}{ll}\text { Significance of the Study } & 6\end{array}$

Research Questions $\quad 7$

$\begin{array}{ll}\text { Summary } & 7\end{array}$

Chapter Two: Review of the Literature $\quad 8$

Membership and Structure $r$

Roles 11

Board Effectiveness $\quad 12$

One: Making rational decisions $\quad 14$

Two: Functioning cohesively as a group $\quad 14$

Three: Exercising appropriate authority 15

Four: Connecting to the community 15

Five: Working toward board improvement 16

Six: Acting strategically $\quad 19$

$\begin{array}{ll}\text { Christian School Context } & 19\end{array}$

Theoretical Framework $\quad 23$

$\begin{array}{ll}\text { Significance of the Study } & 24\end{array}$

Chapter Three: Methodology 26

Type of Research Design 26

Sample, Population, and Participants 27

$\begin{array}{ll}\text { Population } & 27\end{array}$

$\begin{array}{ll}\text { Sample and participants } & 27\end{array}$

Data Collection $\quad 29$

Instrumentation $\quad 29$

Validity 30

Reliability 31

Data collection $\quad 32$

Variables $\quad 32$

Data Analysis Procedures 33

Limitations $\quad 33$

Delimitations $\quad 35$

Ethics $\quad 35$

Summary $\quad 35$ 
Chapter Four: Results $\quad 37$

$\begin{array}{ll}\text { Participants } & 37\end{array}$

Research Questions $\quad 40$

Question 1: What are the Background Characteristics of Christian School $\quad 40$

Board Members?

$\begin{array}{lr}\text { School demographics } & 40\end{array}$

Participant demographics 43

School board characteristics $\quad 52$

Question 2: What Patterns Exist in the Christian School Board Effectiveness 54

Ratings of School Board Members, Presidents, and School Administrators?

Open ended question responses $\quad 56$

Making decisions $\quad 57$

$\begin{array}{ll}\text { Functioning as a group } & 60\end{array}$

$\begin{array}{ll}\text { Exercising authority } & 64\end{array}$

Connecting to the community 67

Working toward board improvement $\quad 70$

Acting strategically $\quad 74$

Question 3: Are there Mean Differences Between the Ratings of Christian 77

School Board Members, Presidents, and School Administrators?

$\begin{array}{ll}\text { Gender differences } & 81\end{array}$

Ethnicity and race differences $\quad 82$

Question 4: What are Some of the Factors that Predict School Board 82

Effectiveness?

Board self-assessment questionnaire correlations $\quad 82$

$\begin{array}{ll}\text { Open ended question responses } & 84\end{array}$

Chapter Five: Discussion $\quad 85$

Summary of Results $\quad 85$

Theoretical Significance $\quad 86$

$\begin{array}{lr}\text { Making decisions } & 86\end{array}$

$\begin{array}{ll}\text { Functioning as a group } & 87\end{array}$

$\begin{array}{ll}\text { Exercising authority } & 87\end{array}$

Connecting to the community $\quad 88$

Working toward board improvement $\quad 89$

$\begin{array}{lr}\text { Acting strategically } & 89\end{array}$

$\begin{array}{lr}\text { Summary } & 90\end{array}$

$\begin{array}{lr}\text { Practical Significance } & 90\end{array}$

Term length $\quad 91$

Board size $\quad 92$

$\begin{array}{ll}\text { Recruitment } & 92\end{array}$

$\begin{array}{ll}\text { Age } & 93\end{array}$

Gender $\quad 94$

Race $\quad 94$

Professional background $\quad 95$

$\begin{array}{ll}\text { Governance structure } & 95\end{array}$ 
Making decisions and functioning as a group 96

$\begin{array}{ll}\text { Exercising authority } & 97\end{array}$

Working toward board improvement 98

Acting strategically $\quad 99$

Recommendations for Future Research $\quad 100$

Model for Christian School Board Effectiveness 102

Conclusion

103

Appendix A Christian School Board Survey 104

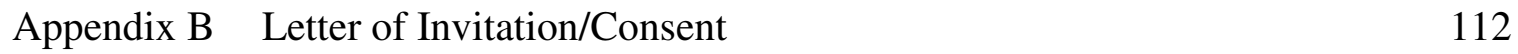

Appendix C Institutional Review Board Approval for the Study 113

$\begin{array}{ll}\text { References } & 114\end{array}$

$\begin{array}{ll}\text { Acknowledgments } & 123\end{array}$ 
List of Tables

Table 1 The Relationship between Smoley's and Holland, Chait, and Taylor's Work on Board Effectiveness

Table $2 \quad$ Sample by School Type $\quad 28$

Table 3 Reliability Coefficients of Six Board Activities (Chronbach's Alpha) 31

Table 4 Respondent Breakdown by School Board Role 38

Table $5 \quad$ Respondent Breakdown by School and School Board Role 38

Table 6 Respondent Breakdown by Grades Served 41

Table $7 \quad$ Respondent Breakdown by Location $\quad 42$

Table $8 \quad$ Respondent Breakdown by School Size 43

Table $9 \quad$ Respondent Breakdown by Setting 43

Table $10 \quad$ Service Year on the School Board 45

Table 11 Age of Christian School Board Members 46

Table 12 Gender of Christian School Board Members 48

Table 13 Race of Christian School Board Members 49

Table 14 Professional Background of Christian School Board Members 50

Table $15 \quad$ Level of Education of Christian School Board Members 52

Table 16 Board Member Expectations of Students that can Achieve at or 53 above Grade Level

Table 17 Percentage of Board Meeting Time Spent on Discussing Student 54 Achievement by Role

Table 18 Descriptive Statistics of Board Governance Activities Scores 55

Table 19 Descriptive Statistics of Board Governance Activities by Board Role 56

Table 20 Descriptive Statistics of Making Decisions 57 
Table 21 Descriptive Statistics of Functioning as a Group 60

Table 22 Descriptive Statistics of Exercising Authority 64

Table 23 Descriptive Statistics of Connecting to the Community 67

Table 24 Descriptive Statistics of Working toward Board Improvement 71

Table 25 Descriptive Statistics of Acting Strategically 75

Table 26 Number of Items Significantly Different than Model Mean 77

Table 27 One-Way ANOVA of Board Member Evaluation by Role 78

Table 28 One-Way ANOVA of Authority-Accepting Administrator's 79

Table 29 One-Way ANOVA of Authority-President/Administrator Conferring 80 by Role

Table 30 One-Way ANOVA of Working toward Board Improvement by Role 81

Table $31 \quad$ Pearson Correlations between Demographic Variables and 83 BSAQ Scores 


\begin{abstract}
This exploratory study investigated the effectiveness of Christian School boards, as perceived by its members, and examined patterns and characteristics that describe internal board activities. The study employed a quantitative survey research design that revealed areas of strength and areas of growth for Christian School board operations. Board effectiveness was measured in accordance with Smoley's (1999) Model for Effective School Boards.
\end{abstract}

The research focused on four questions: (a) What are the background characteristics of Christian School board members? (b) What patterns exist in the Christian School board effectiveness ratings of school board members, presidents, and school administrators? (c) Are there mean differences between the ratings of Christian School board members, presidents, and school administrators? and (d) What are some of the factors (e.g. role on the board, school characteristics, and board member characteristics) that predict school board effectiveness ratings?

Data were collected through an online survey of 37 Christian School boards in Iowa, Minnesota, South Dakota, and Wisconsin. The survey was completed by 217 school board members, school board presidents, and school administrators.

The analysis of the demographic data revealed that Christian School boards are primarily comprised of well-educated, White, middle-aged men from business and/or professional backgrounds. Internal school board activities data revealed that Christian School boards perceive themselves to be highly effective at making rational decisions and moderately effective at connecting to the community. The data also revealed that, when compared to Smoley's (1999) Model for School Board Effectiveness, Christian School 
board self-perceptions fell short in the areas of functioning as a group, exercising authority, working toward board improvement, and acting strategically. The difference was particularly pronounced in the area of working toward board improvement.

The research findings suggest implications for the work of Christian School boards, namely the vociferous need to diligently examine internal board activities and their effect on external outcomes. Future studies should center on the demographic representation on the board and the benefits of professional development directed to the school board itself. Attention to these implications and recommendations will contribute to strengthening the internal work of the Christian School board and, ultimately, student achievement. 


\section{Chapter One: Introduction}

\section{Background to the Study}

In the last quarter century, education criticisms and reforms were primarily directed to teachers and school administrators. School boards were left out of the spotlight (Coleman et al., 2004; Danzberger, 1994). This focus changed in 1992 with the publication of Governing Public Schools: New Times, New Requirements (Smoley, 1999) which called for restructuring school board roles and operations in order to meet the new demands of education. Since that time, and especially in the last decade, school boards have received increased attention in research regarding their role in the comprehensive education of the nation's children through key studies by, among others, The Twentieth Century Fund, the Institute for Educational Leadership, and the Education Commission of the States.

Today, public school boards are increasing their concentration on the relationship between student achievement and school board practices. This concentration comes as a result of studies (Goodman, Fulbright, and Zimmerman, 1997; Rice et al., 2000) which have found that schools with quality governance, however defined, tend to have higher student achievement. Numerous other researchers (Black, 2007; Feuerstein and Dietrich, 2003; Hess, 2002; Land, 2002; Lashway, 2002) have also explored what role the school board has toward increasing student achievement.

The aforementioned studies reflect the belief that public school boards have an impact on what happens in schools. Former United States Secretary of Education, Rod Paige (2002), reiterated this belief with stronger words: "Without a doubt, the entity with the greatest influence on the quality of school district effectiveness is the school board" 
(p. 4). Public school boards understand that the time is ripe for continued research on the role of school boards in this age of educational reform (Forbes and Millikan, 2004).

\section{Statement of the Problem}

While research on public school boards has generated new perspectives on leadership in public schools, it has failed to address some of the unique challenges facing Christian School boards. Whereas public school boards face pressure from laws requiring greater accountability such as the No Child Left Behind (NCLB) Act of 2001, Christian School boards are free from this pressure, since NCLB and many other governmental regulations have no direct influence on nonpublic schools. Less regulation creates more autonomous roles for Christian School boards. Although “widespread public concern for...the future of public education" (Conley, 2003, p. 71) is well established, concern for nonpublic education, specifically Christian education, and improving its leadership, appears miniscule as it is not addressed in any mainstream educational literature.

Anecdotes from conversations with Christian School administrators indicate their belief that Christian School board members, with a few exceptions, are dedicated to serving their constituency well. Board members who are unfamiliar with the roles and responsibilities of their position, however, can derail the board's purpose of creating an environment that "prepare[s] children to live lives of service to God and man" (Elve, 1982, p. 17). While the long-term vision and mission of preparing God's servants is the ultimate goal of the board, it appears that Christian Schools are facing more immediate sustainability concerns of keeping schools open. A review of topics from Christian Schools International's leadership conventions, publications, and presentations from the last few years reveals some of the pressing issues facing Christian School boards. Some 
of these topics include: The Shifting Culture of Christian Schools, The Challenges of Organizational Structures, Addressing Change, Financial Success for Schools in Tough Economic Times, and Re-Thinking Admissions Policies.

While the issues of culture, structure, change, finance, and admissions must be addressed in order for Christian schools to remain open, it is imperative that another issue be addressed: Are Christian School board members equipped to handle these challenges? Smoley (1999) found that public school boards are not always equipped to operate as effectively as they could. But what about Christian School board members? Are they prepared to lead? Although little research has been performed primarily with Christian School boards, there is a body of research on non-profit organizations that can help Christian School boards better understand what it takes to be an effective board.

In measuring non-profit board effectiveness, for example, Herman and Renz (1999) learned that boards traditionally measure effectiveness in accordance with progress toward organizational goals. Anecdotes from conversations with Christian School board members revealed that their organizational goals include steady or increasing enrollment, contented faculty and staff, and a balanced budget. These measures could be considered as outputs or functions of the board. What these measures fail to take into account, however, are the internal processes of how the board operates (Cornforth, 2001). Indeed, it is the process of Christian School board operations that must be researched in order to determine if Christian School boards are ready to solve the challenges they face. Many boards are so consumed with the pressing current issues that they lack the time and knowledge to best address them. The decline of staunch church support, both financially and with students, has caused a heightened concern about the 
sustainability of "the vision of God's kingdom that generated the Christian school movement" (Cooper, 1998, p. 4).

Bradshaw, Murray, and Wolpin (1992) found that non-profit Chief Executive Officers (CEOs) rated the performance of their boards higher when boards were more involved in strategic planning. While this result may be true of the CEOs' assessment of effectiveness, it does not consider how effective the board members themselves believe they are. Furthermore, the subjects for the study did not include school administrators (i.e. the school CEO) or school board members. If we are to understand the operations of Christian School boards, then the focus of the initial study should include only Christian School board members in order to gain a targeted view of their specific practices.

Using multiple data sources, Green and Griesinger (1996) examined the presence of 30 board practices to measure the effectiveness of non-profit CEOs and board members. Their findings indicated a divergence between CEOs and board members when measuring the relationships between board practices and board effectiveness. Is the same divergence evident in Christian School boards? Do school administrators and board members assess effectiveness differently?

Board practices were also the focus of research by Herman and Renz (1997). They researched evidences of 25 recommended board practices in their study of most and least effective non-profit organizations. They found that the top ten organizations used more of the recommended practices as compared to the bottom ten. In addition, a strong correlation was found between the implementation of these practices and organizational effectiveness. If this correlation is evident in non-profit organizations, is the same true in Christian schools? 
In their study of private colleges and seminaries, Jackson and Holland (1998) found strong evidence that effective organizations are related to effective boards. Moderate correlations were identified between six components of effective boardsmanship and the overall score on their survey instrument. They also found that the intervention of board training increased the scores on the instrument.

The lack of research specifically directed to Christian School boards is unfortunate. These boards are composed of dedicated volunteers who are interested in the school's mission, but they lack the training to lead and complete the difficult work they face (Hekman, 2006; Smoley, 1999). Whereas public school board members receive structured training from state and local agencies, Christian School boards often receive no training. It is imperative that board members understand what it takes to operate effectively in order to maintain their ultimate responsibility for the direction of the school. The aforementioned research reveals that there is a connection between board practices and board effectiveness and that intervention and training can improve the effectiveness of boards. This current study sought to examine the practices of Christian School board members under Smoley's (1999) conceptual Model for Board Effectiveness to identify practices that can assist members in being more effective.

\section{Purpose of the Study}

The purpose of this study was to determine if there were statistically significant differences in effective board actions of school administrators, board presidents, and board members in an association of Christian Schools in five Midwestern states. This study also intended to examine the relationship between demographic characteristics and the effectiveness of school boards. Demographic characteristics were divided into 
background information about the respondent and background information about the institution in which the respondent served. The examination of this information was intended to help identify characteristics and factors that might contribute to significant differences in board effectiveness.

Effectiveness was measured by administering Smoley's (1999) Board SelfAssessment Questionnaire (BSAQ). The survey questions addressed the six elements of effective board actions identified by Smoley (1999) in his conceptual Model for Board Effectiveness: (1) making decisions, (2) functioning as a group, (3) exercising authority, (4) connecting to the community, (5) working toward board improvement, and (6) acting strategically.

\section{Significance of the Study}

This study is important because school board roles in the greater arena of school reform have been understudied and not researched as a discrete unit of analysis (Land, 2002). The paucity of research is even more evident in the Christian School setting. The larger body of school board research has focused strictly on the relationship between the school administrator and the board rather than considering the entirety of the board in their own right (Land, 2002). This study examined Christian School boards as a whole.

It is essential for boards to understand that meeting the challenges of leadership begins with a careful evaluation of the school board itself and that board evaluation and improvement take time (Hekman, 2006). The results of this study can help Christian School boards gain a clearer picture of how effectively they are implementing Smoley's (1999) six actions of effective school boards and identify areas in which they can 
improve. It serves to provide insight into the demographics of those serving on Christian School boards.

Research Questions

The overarching question guiding this study was: How effective are the actions of Christian School boards? The following questions helped guide the study of this broader question:

1. What are the background characteristics of Christian School board members?

2. What patterns exist in the Christian School board effectiveness ratings of school board members, presidents, and school administrators?

3. Are there mean differences between the ratings of Christian School board members, presidents, and school administrators?

4. What are some of the factors (e.g. role on the board, school characteristics, and board member characteristics) that predict school board effectiveness ratings?

\section{Summary}

A better understanding of board process and behaviors is needed (Forbes and Millikan, 2004). Studies around the world (Bradshaw, Murray, and Wolpin, 1992; Green and Griesinger, 1996; Herman and Renz, 1997; Herman and Renz, 1999; Hofman, Hofman, and Guldemond, 1999; Hofman, Hofman, and Guldemond, 2002; Jackson and Holland, 1998; McCormick, Barnett, Alavi, and Newcombe, 2006) have confirmed the impact of effective board management on effective organizations. Studies about the effectiveness of Christian School boards within the broader arena of nonprofit organizations are long overdue. 
Chapter Two: Review of the Literature

In order to study the effectiveness of Christian School boards, it is important to begin by looking at the results and discussion of prior research and literature. Since there is a paucity of research on nonpublic school boards, it is helpful to examine research on similar boards. What do we know about effective public school boards, corporate boards, and non-profit boards? How do these findings relate to effective practices of Christian School boards?

A search of databases such as EBSCOHost Academic Search Elite, Educational Resource Information Center (ERIC), and the Professional Development Collection reveals numerous studies focused on school boards. Very little of the research, however, has been done in Christian schools. One goal of this study was to add to the field by expanding current research to include Christian School boards. Although the focus is on Christian School boards, it is believed that the findings will also be helpful for other types of nonpublic school boards and for other nonprofit boards in general. Current literature on school district boardsmanship includes, but is not limited to, the following three themes: membership and structure, roles, and effectiveness. Since the unique features of Christian schools in this study may be new to the reader, a section is included on the history and development of these schools.

\section{Membership and Structure}

Mountford (2004) states that "school board membership is without great rewards" (p. 706). Partly due to the lack of great rewards and partly due to the challenging work, school boards continue to be composed of primarily part-time laypeople (Kirst, 1994; Czubaj, 2002). Christian School board members are all volunteers whose demographics 
are unknown. A study of public school board members (Hess, 2002) reported the racial composition of public school boards to be 85.5 percent White, 7.8 percent AfricanAmerican, 3.8 percent Hispanic, and 2.3 percent other races. Gender representation was reported as 61.1 percent male and 38.9 percent female. Diversity on boards is important for effective governance, yet should not sacrifice "agreement on a common set of assumptions about the institution and its mission" (Bowen, 2008, p. 142). While some governing boards earmark seats to increase the diversity of the board, Bowen (2008) argues that earmarking is "patronizing and an inadequate response to the opportunity to enrich a board by recruiting outstanding individuals of diverse backgrounds" (p. 143).

In the public sector, it is important that members are selected through a rigorous and systematic process (Frankel and Schechtman, 2006). Most often, they are selected through a stable election structure that "may contribute to the stability of representation in elections over time" (Allen, 2005, p. 522), meaning that turnout is consistent and the influence of special interest groups is kept to a minimum.

The election process for the Christian schools in this study is unique. Board members are neither elected in the same manner as in public schools nor are they appointed as is the case in some mayoral-led public schools. Rather, Christian School board members are usually 'quasi-elected.' Christian School constituents (parents, grandparents, and other supporters) nominate persons to be considered for impending openings on the school board. The sitting school board considers these nominations, as well as those from current board members, and makes the final decision regarding which names will be placed on the ballot. These people are contacted to confirm their willingness to have their names on the ballot. In most cases, two names are placed on the 
ballot for each open position. The constituency is then invited to vote for new members. In this manner, the current school board can choose persons to be on the ballot who support the mission and vision of the school and who may fill a specific leadership need on the board. Christian School board members are primarily parents who volunteer for service and, in general, have a stronger connection to the school constituency (Hofman, Hofman, and Guldemond, 2002). Hofman, Hofman, and Guldemond's (2002) research acknowledges the difference between public and nonpublic school governance structures, but it does not address the induction programs, or lack thereof, for Christian School board members. Their research also did not address school board effectiveness measures. In addition, Hofman, Hofman, and Guldemond (2002) found "that coherence between school governors, school leaders, teachers and the school community (parents) produces a sense of community that, in turn, shapes conditions in schools that have a positive effect on pupil achievement" (p. 249). This connection between home and school is well documented in other studies as a key factor in student success in school, one that public school districts have been working toward with less success (Boyle, 2004; Bryk, Lee, and Holland, 1993; Epstein, 1985). Hofman, Hofman, and Guldemond (2002) also found that the governance structure of nonpublic schools was a statistically significant contributor to school and classroom effectiveness. They even discovered that the structure of governance had a more significant effect on achievement than did classroomlevel variables. By structure, they mean that there is a connection between classroom effectiveness and how well nonpublic school boards address the input of community members, teachers, administrators, and parents, on school board decisions. This connection was found to be significantly higher in nonpublic than public schools. This 
situation begs the question: What is happening in nonpublic school governance that is having such a profound effect on student achievement? Are school boards a key factor? This research appears to confirm the relationship between board leadership and overall school effectiveness in an environment of mutual agreement between school administrators and board members.

Roles

School board members cannot be effective if they are unaware of how their roles must adapt to fit the needs of schools and the greater society. Kirst (1994) maintains that "if school boards do not change, then the erosion of their influence on policy making will most likely continue" (p. 381). Board members must understand how societal changes and changing values (i.e. renewed focus on student achievement) can influence the direction of schools and the role school board leadership has in creating an environment in schools that prepares students for a changing world (Boyle, 2004; Hunt and Blanchard, 1990; Kirst, 1994; Opfer, 2001).

While public schools may feel pressure from governmental regulations such as NCLB, the pressure on Christian schools, as mentioned earlier, is related more to the sustainability of the institution itself. It may only be a matter of time, however, before Christian schools feel the same push for improving student achievement as their public counterparts. Progress reports under NCLB are revealing some increased achievement levels in public schools. Are Christian schools improving at the same rate? Are they meeting state standards at the same level? Even Iowa, the longstanding holdout against state standards, recently adopted a Core Curriculum with standards for all accredited schools in the state-public and nonpublic alike. Board members can no longer get by 
without understanding the connections between standards-based reform and student achievement (Feuerstein and Dietrich, 2003). It is essential that decisions are based on relevant information and regulations (Smoley, 1999).

Christian School boards act in the same collective manner as their public school counterparts. While leadership of the organization is a collective board responsibility, leadership of the board itself is the responsibility of the board president (McCormick, Barnett, Alavi, and Newcombe, 2006). In most cases, the school administrator and the board president work together to lead the board, including board meetings. Although Christian School administrators serve under the board, it appears that they serve more with the board than is evident in the public school sector (McCormick, Barnett, Alavi, and Newcombe, 2006).

\section{Board Effectiveness}

Historically, a common approach to board effectiveness has been to identify various board actions or functions and assess how well these are being carried out (Cornforth, 2001). Studies that follow this approach often ask a sampling of board members, CEOs, or supporters to assess each of the identified functions. In sum, board effectiveness is measured according to a set of school board actions that are mutually agreed on as marks of effective school boards. Boards that demonstrate higher levels of implementation of these best practices are considered to be more effective. One of the most widely used examples of this approach is the Model of School Board Effectiveness which identifies six core actions of effective school boards (Smoley, 1999). It should be noted that this approach is not outcome or goal-oriented; rather, it is a measure of how boards operate toward meeting goals and expectations. 
The Model of School Board Effectiveness was built on research done with experts and school board members themselves. The model is an outgrowth of the School Board Effectiveness Project, begun in 1993 by Eugene R. Smoley, Jr., and funded by the Good Samaritan Foundation. Smoley (1999) conducted interviews with school board members centered on three topics: measuring progress of the schools, assessing board operations, and priorities for board improvements. Interviewees were presented with critical incidents and asked to describe how their board acted toward each incident. From these interviews, themes were extrapolated and the Model of School Board Effectiveness was developed to include six non-hierarchical categories of board actions. These six actions are considered to be the marks of an effective school board:

1. Making rational decisions

2. Functioning cohesively as a group

3. Exercising appropriate authority

4. Connecting to the community

5. Working toward board improvement

6. Acting strategically

Smoley's (1999) work with school board actions is grounded in the work of Holland, Chait, and Taylor (1989) with college and university board actions who also identified six competencies but named them: contextual, educational, interpersonal, analytical, political, and strategic. Table 1 depicts the relationship, as analyzed by Woodward (2006), between the themes identified by Smoley (1999) and Holland, Chait, and Taylor (1989). 
Table 1.

The Relationship between Smoley's and Holland, Chait, and Taylor's Work on Board Effectiveness

\begin{tabular}{ll}
\hline Smoley & Holland, Chait, and Taylor \\
\hline & \\
Making rational decisions & Analytical \\
Functioning cohesively as a group & Interpersonal \\
Exercising appropriate authority & Contextual \\
Connecting to the community & Political \\
Working toward board improvement & Educational \\
Acting strategically & Strategic \\
\hline
\end{tabular}

Source: Woodward (2006)

A few other studies have also identified actions of effective school boards, many of which are similar to those of Smoley (1999). The recommendations from these additional studies are integrated under the respective actions identified by Smoley (1999) and outlined below. Inclusion of these ideas adds validity to Smoley's (1999) conceptual Model for School Board Effectiveness.

One: Making rational decisions.

Effectiveness in this category is marked by rational decision-making that is informed by data and full discussion (Smoley, 1999). There is flexibility to consider alternative courses of action through a process of consensus, rather than merely through a majority vote (Smoley, 1999).

Two: Functioning cohesively as a group.

Effectiveness in this category is marked by respect, trust, and cohesiveness. Members' work together is governed by shared goals, values, and operating rules (Smoley, 1999). Lister (2007) refers to this construct as working and playing well with others. Cornforth (2001) examined effectiveness of nonprofit boards and found developing a common vision (i.e. shared goals and values) to be the most statistically 
significant predictor of organizational effectiveness. Unfortunately, research shows that many school boards struggle to function as a unified body (Land, 2002).

Three: Exercising appropriate authority.

Effectiveness in this category is marked by support and consideration of the administrator's recommendations while exercising caution to not rubber-stamp them. Members make decisions withstanding pressures from employees and/or the constituency (Smoley, 1999). Cornforth (2001) emphasized the clarity of board roles as a factor of exercising appropriate authority. This can be difficult when oftentimes boards inherit "an ambiguous structure of authority" (Wong, 1995, p. 571). One key to avoiding this ambiguity is for boards to recognize that the board president sets the tone and is central to a well-functioning board (Good, 2007). Furthermore, all members must not only respect the role of the school administrator (Campbell and Greene, 1994), but they must also recognize the relationship between effective school administrators and the level of student achievement (McREL, 2006).

The degree to which boards exercise appropriate authority varies between and within school types. Hofman, Hofman, and Guldemond (2002) identified basic governance organizational differences between public and non-public schools. They found the decentralized structure of non-public schools allows the organization to function better as opposed to the more politicized structure of public schools (Hofman, Hofman, and Guldemond, 1999).

Four: Connecting to the community. Effectiveness in this category is marked by strong formal and informal connections between school boards and the supporting constituency (Smoley, 1999). 
Coleman et al. (2004) emphasize the role of boards as the connection between households and schools. Eadie (2007) notes the importance of boards being "explicitly accountable" (p. 64) to their communities. School boards are to represent and be responsive to the public through its membership and governance (Land, 2002; McCormick, Barnett, Alavi, and Newcombe, 2006).

In non-public schools, Hofman, Hofman, and Guldemond (2002) noted the importance of constituent participation as a highly relevant factor in the success of nonpublic schools since board decisions are more in line with parent's wishes. They included the higher levels of participation of teachers and administrators in decision-making as additional key factors for higher achievement in non-public schools. Astonishingly, their study found that the effect of school governance characteristics mediated the effect of attending a non-public school. In other words, the structure of the board itself was found to have a greater effect on student achievement than the fact that the school was not a public school. Eskeland and Filmer (2007) attributed high levels of student learning to the factors of board autonomy and parental participation. In the same vein, LaRocque and Coleman (1993) reported that schools with positive community connections have a culture that is associated with high levels of student achievement.

\section{Five: Working toward board improvement.}

Effectiveness in this category is marked by working toward improvement through training for new members, reflecting on board responsibilities, and seeking assistance as needed (Smoley, 1999). Boards which intentionally and diligently work on improving themselves understand that school board governance requires sophisticated leadership (Hopkins, O'Neil, Williams, 2007). Sophisticated leaders recognize that "the board is 
responsible for its own development, its own job design, its own discipline, its own performance, its capability to envision and plan for the future" (Carver, 2006, p. 189).

Boards should also recognize that recruiting members is a difficult task. They need to be cautious to recruit members who truly understand what it takes to be an effective board member (Bowen, 2008). Once elected or appointed, Cornforth (2001) recommends training for new board members and a regular review process of board performance. Jackson and Holland (1998) emphasize the importance of training board members to plan for the organization's future with a structured strategic planning process. Coleman et al. (2004) affirmed the importance of board training by stating that board effectiveness will increase if members are engaged in continued professional development. This includes a minimum of one meeting per year where the head administrator and the board assess the needs of the board as a whole, in addition to the needs of individual members to meet the increasing demands from constituents and legislative bodies. Eadie (2007) sees constant development of knowledge and skills as the key to high-impact school boards.

Most boards have a sense of how they are doing, but they are unable to assess performance or make subsequent plans for improvement (Manley, 2005). They see value in self-evaluation, but it is unclear how many have formal evaluation procedures in place (Bowen, 2008). Boards may not know where to begin, but those who diligently work toward assessing and improving their performance can make gains (Holland and Jackson, 1998). Amidst recognition that self-evaluation may be helpful, most boards still fail to evaluate themselves regularly (Land, 2002). 
Whereas twenty states have mandatory training for local public school board members (NSBA, 2008), this is not the case in nonpublic settings. New board members should be "oriented to independent (non-public) education and effective school governance through a thorough process" (Frankel and Schechtman, 2006). School administrators recognize the importance of mandatory board training (Petronis, 1996), but it is essential that board members take the lead on this front. Board members without training threaten the very heart of public and nonpublic school governance as the demands of education are complex (Smoley, 1999). Simply having children in school is not qualification enough to serve on the school board (Education, 2008). Board members must understand the complexities of governance, political environments, community dynamics, and the pressures of each (Besought, 2002; Campbell and Greene, 1994; Smoley, 1999; Coleman et al., 2004).

Boards which work to regularly develop knowledge and skills have high levels of impact (Eadie, 2007). Unfortunately, many boards fail to realize that it is the board's responsibility, not the school administrator, to educate themselves (Carver, 2006). School administrators should not have to nurture board members that are unprepared to make effective decisions (Chalker, 1992). Failure to adequately train board members leads to ineffectiveness due to an unclear understanding of duties that are essential to boardsmanship (Campbell and Greene, 1994). Hopkins, O’Neil, and Williams (2007) identify six competencies for effective school board members: transparency, achievement orientation, initiative, organizational awareness, conflict management, and teamwork and collaboration. While this list may not be comprehensive, it is a good framework on which to build a board training program. 


\section{Six: Acting strategically.}

Effectiveness in this category is marked by discussing and acting on issues that help students learn. Members focus on long-term planning, adjusting to current and anticipated demands and mandates from the constituency and government bodies. There is also clear understanding of board and administrator roles (Smoley, 1999). Developing strategy was also included in Cornforth's (2001) findings. Coleman et al. (2004) expanded the concept of developing strategy to include a focus on student achievement since the goal of schools is the education of its students.

The ability of a board to act strategically is the most important determinant of overall board effectiveness (Bradshaw, Murray, and Wolpin, 1992). What is unknown, however, is whether strategic planning leads to effective school boards or if effective school boards are naturally good at strategic planning (Herman and Renz, 1999). In schools where strategic planning is not taking place at appropriate levels, it is often the result of the school administrator taking the lead in the process (Archer, 2002). It is essential for the board to recognize its role in leading the long-range planning process. Strong lines of communication between the board, administrator and the constituency increase the chances of goals being met (Campbell and Greene, 1994).

In order to correlate the Model for School Board effectiveness with Christian School boards, it is necessary to outline the historical development of Christian schools.

\section{Christian School Context}

The founders of the Christian schools examined in this study did not intend to create school systems that were completely independent of state and federal regulations. Christian School leaders understood the importance of state and federally mandated 
requirements for all schools to "insure an adequate education for all children" (Erickson, 1969, p. 103). There has been and continues to be disagreement among policy makers, however, regarding the level of state control needed in nonpublic schools (Erickson, 1969). In general, state regulations in nonpublic schools were designed to reinforce school attendance requirements and a standard level of preparation for service in society. While some political leaders are concerned that looser regulations endanger children, others see regulations as threatening the very purpose on which nonpublic schools were founded (Erickson, 1969).

In the fall of 2005, the National Center for Education Statistics (NCES) estimated that 13 percent of K-12 students in the United States were enrolled in non-public educational settings. This percentage accounts for over four million students in nearly 29,000 schools. Nearly 80,000 (2.2\%) of these students attend schools affiliated with Christian Schools International (CSI). The oldest members of this group of schools, a sampling of which constitutes some of the participants in this study, were founded over 100 years ago by Dutch immigrants as parochial schools. These schools were governed by the church and, as in the church services, included Dutch as the primary language of instruction. The goal of the school was to prepare children for life in the congregation (Zwaanstra, 1998). Christian schools were (and continue to be) distinctive from public schools in two key areas: the commitment to teaching with a Biblical world and life view and the context of working with families who believe in the God in whose name the students are taught (Illman, n. d.).

After 1890, the Christian Reformed Church went through some rapid and fundamental changes. Signs began to appear above school entrances reading "American 
Christian School" and the purpose of schooling began to change. The mission changed to preparing children not only for life in the congregation, but also for life in American society with the primary language of instruction being English. In turn, the schools were no longer owned and operated by the church. Christian parents viewed the Christian nurture and education of their children as primarily a parental responsibility. Christian instruction, as outlined in Deuteronomy 6:7 (New International Version), was to be a 247 endeavor: "Impress [these teachings] on your children. Talk about them when you sit at home and when you walk along the road, when you lie down and when you get up." The church relinquished the denominational enterprise of Christian day schooling of children and turned over school ownership and operations to the parents. By 1920, this small but growing number of Christian schools saw the need to organize under a common leadership organization, the National Union of Christian Schools (NUCS). For the next 57 years, membership continued to grow as more schools opened and joined NUCS. All member schools were strongly connected to the Christian Reformed Church in North America.

In 1977, members and leaders of NUCS expressed the importance of member schools and their constituencies to include a broader scope of all believers. NUCS was thus transformed into Christian Schools International (CSI). Schools from a broader Reformed community, such as many Presbyterian and other parochial schools in the South, began joining CSI. In the 1990s, CSI began recruiting members of urban Christian Schools to join its membership. These established urban schools were also seeking connections with other Christian schools. 
CSI does not usurp the role of parents controlling each individual school, but was established and continues to provide services to schools such as leadership development, administrator search services, a nationwide employment network, consulting services, Christian curriculum publications, a nationally recognized accreditation service, and a comprehensive employee benefit program. CSI currently serves over 500 schools and 100,000 students across North America. Its mission is service To All Believers in

\section{Education.}

School boards in Christian schools are entrusted by parents to ensure that students are instructed to "not conform any longer to the pattern of this world, but be transformed by the renewing of your minds" (Romans 12:2; Beversluis, 2001; Elve, 1982; Haan, 1993). The Reformed faith on which many of these Christian schools are founded reveals itself in the classroom through an emphasis on the sovereignty of God over all of creation, including education, and its redemption (Zylstra, 1999; Nederhood, 1990). All academic subjects are taught in the light of scripture and God's revelation of himself in a coherent and harmonious creation, to the community of believers, through the spheres of each and every academic discipline (Nederhood, 1990; Van Dyk, 1985). This distinct Biblical perspective, one that is absent in public schools, sees "God's revelation in every dimension of the universe" (Van Dyke, 1985, p. 2) and views creational truth as incomplete without scriptural truth. This "hallmark of the Reformed approach to Christian education" (Cooper, 1998, p. 5) is the worldview that should underlie the actions of Christian School board members.

The ultimate goal that school boards are entrusted with, though not understood nor embraced by all members to the same degree, is creating a learning community where 
students learn to be a light in this dark world and where teaching focuses on religious growth in order to give students tools to test the spirits of this world (Beversluis, 2001, DeKorne, 2003; Van Dyk, 1985). Students are trained to bring Christ's light to a darkened world through every occupation and mode of service (Vander Ark, n. d.; Van Dyk, 1985). This training takes place alongside that of the home and the church as representatives of the larger Christian community (Van Dyk, 1985) where all three stand together and, in the words of Abraham Kuyper, a renowned Dutch Calvinist Reformer, proclaim "There is no square inch in the whole domain of our human existence over which Christ, who is Sovereign over all, does not cry 'Mine!'” The Christian school and its leaders use this idea not as a defense of Christian activism, but rather as a foundation for a holistic view of curriculum and instruction centered on training students to use their abilities to serve others and to be cognizant of God's call to vocation in his Kingdom (Van Dyk, 1985). These are the core principles on which Christian schools have been established and which board members have been entrusted to uphold.

\section{Theoretical Framework}

This study is grounded in Smoley's (1999) conceptual Model for School Board Effectiveness. His work was developed as an outgrowth of the original work on school board effectiveness by Jackson and Holland (1998) in which board leaders were surveyed about the effectiveness of the boards on which they served. This conceptual framework fits the inquiry approach of self-assessment of effective school board actions used in this study. Smoley's (1999) framework includes descriptive categories for exploration via survey research (Shields and Tajalli, 2006). The framework has been useful in identifying and analyzing areas in need of improvement for school boards (Jackson and Holland, 
1998). As applied to this study, the framework holds that more effective school boards have higher survey ratings than less effective school boards. All responses were compared to an average response of " 2 " or "Agree" on a four-point scale that runs from three to zero with 3=Strongly Agree, 2=Agree, 1=Disagree, and 0=Strongly Disagree.

Smoley's (1999) conceptual framework provided an excellent fit for this study since it had been tested extensively with public and non-profit boards (Jackson and Holland, 1998), but it had not been tested in Christian schools. Since Christian School boards have similar characteristics to those of public school and non-profit boards, Smoley's (1999) framework provided insight on effective school board actions. It helped individual members and boards as a whole to identify which areas of board operations are being demonstrated strongly and which areas may be in need of improvement.

\section{Significance of the Study}

This study is unique in that, to the knowledge of the researcher, it is the first of its kind to assess the effectiveness of nonpublic school boards. Due to the scarcity of research on nonpublic school boards, this study serves as an introduction to the structure and processes of this unique group of leaders. It provides nonpublic school board members with clear understanding of effective policies and practices that contribute to holistic school improvement. Since this study relied on the work being accomplished in public school board research such as that by Alsbury (2008), Rice et al. (2000), Land (2002), LaRocque \& Coleman (1993), and others, it is hoped that this study will begin to build a knowledge base for Christian School boards. Results of the study were disseminated to participating school boards and also to Christian Schools International. Finally, by examining perceptions of board effectiveness, members will see the need for 
initial and ongoing professional development for the board itself and demonstrate actions of effective school boards that lead to effective high-achieving schools. 


\section{Chapter Three: Methodology}

It could be argued that both quantitative and qualitative approaches could provide helpful insights into the effective practices of Christian School boards. Considering the connection between this inquiry and the previously outlined studies, the positivism inherent in quantitative survey research was most appropriate for this particular research study. The objective nature of a positivistic survey provided an objective collection of actual experiences from participants (Crotty, 1998) and included a logical, organized structure on which future inquiry can be built. Furthermore, the well-established predesigned survey used in this study provided the high level of reliability needed for administration to a different group of board members. Since this research implemented an established conceptual framework in a new setting, a quantitative survey was best suited for testing the relationships between the independent and dependent variables embedded in the research design.

\section{Type of Research Design}

In order to address the research questions, a quantitative survey research design was employed for this study, in accordance with similar research by Smoley (1999) and his contemporaries. The purpose of this survey was to generalize inferences about the effectiveness of school boards in nonpublic schools. A survey was a good fit for this study due to the economy of the design and the ease of data collection from participants spread across five states. The survey was cross-sectional as data were collected at a single point in time (Creswell, 2003). Administration of the survey took place online to provide participants with convenient access to the instrument and to provide the researcher with inexpensive and efficient data collection tools. The survey used was the Board-Self 
Assessment Questionnaire (BSAQ) published in Appendix B of Effective Schools Boards: Strategies for Improving Board Performance by Smoley (1999). In addition to the BSAQ, the researcher included additional demographic questions in order to address the research questions under consideration.

Sample, Population, and Participants

\section{Population.}

The target population for this study was nonpublic school boards in the United States that are members of Christian Schools International and that govern parentcontrolled schools. This population includes approximately 350 school boards. This estimate was made by examining the 2006 CSI membership directory and removing parochial (church-controlled) schools from the count. Parochial schools were not included in the target population due to significant differences in governance structure. In parochial schools, the pastor and/or consistory of a given church or the creeds of a specific denomination are often the chief authority in school decisions.

\section{Sample and participants.}

For this study, the school administrator and school board members from CSI schools in five upper Midwest states were purposefully selected to participate. The sample included 456 board members and 52 school administrators from 50 schools. These schools were chosen because of their geographic proximity to one another, their previous connection as districts five and six within CSI, and their general representation of size and type of schools across CSI. After the study was completed, it was discovered that the data obtained from CSI was inaccurate and, in turn, the sample and participants did not represent type ratios as shown in Table 2 . 
Table 2.

Sample by School Type

\begin{tabular}{lrr}
\hline & \multicolumn{2}{c}{ Number of Schools (\%) } \\
\cline { 2 - 3 } Grades Served & \multicolumn{1}{c}{$\begin{array}{c}\text { Christian School } \\
\text { Board Survey }\end{array}$} \\
\hline Elementary & $177(52 \%)$ & $37(74 \%)$ \\
Secondary & $24(26 \%)$ & $6(10 \%)$ \\
PK-12 & $38(22 \%)$ & $7(14 \%)$ \\
\hline
\end{tabular}

As a former school administrator in this region of schools, the researcher anticipated that close affiliation with CSI school leaders would provide a high level of trust and, in turn, a higher response rate on the survey. A response rate of 70 percent or better was the goal, which is appropriate when multiple reminders are sent out as was done in this study (McMillan and Schumacher, 2006).

The researcher chose to survey all school board members and head administrators since many previous studies on board effectiveness included only one or the other. It is recognized that all school board members have leadership responsibilities, but the leadership role of the board president is unique (McCormick, Barnett, Alavi, and Newcombe, 2006). For this reason, in some instances, board president responses were identified separately from the responses of other board members. Results provided the opportunity to see if the leaders of the board (the president and, in some cases, the school administrator) viewed the actions of the school board differently than the rest of the members. It was anticipated that the response rate from school board presidents and school administrators would exceed $70 \%$ since these persons are more vested in the leadership of the board and, in turn, likely to be more interested in examining the work of the board as a whole. The final response rate for school administrators was $97 \%$ with 
only one administrator not completing the survey. Thirteen board presidents did not complete the survey, resulting in a response rate of $65 \%$ for presidents. Although this was below the goal, it is still provides useful information for the purpose of this study.

\section{Data Collection}

Instrumentation.

Data were collected using Smoley’s (1999) Board Self Assessment Questionnaire (BSAQ) survey instrument. This 73-item survey, originally published by Chait, Holland, and Taylor (1996) rated the Six Competencies of Effective School Boards that comprise the conceptual framework for this study: making decisions, functioning as a group, exercising authority, connecting to the community, working toward board improvement, and acting strategically. Demographic items were included at the beginning of the survey to accommodate measurement of independent variables. A copy of the survey is found in Appendix A. Written permission for use of this survey was obtained electronically from Tom Holland. Research has shown that board questionnaires are effective in helping board members identify effective actions (Smoley, 1999; Cornforth, 2001). On the BSAQ, participants rated their experience with each item, choosing from four possible responses: strongly agree, agree, disagree, or strongly disagree. Sample statements for each competency are listed below:

$\underline{\text { Making decisions }}$ - (1) This board works to reach consensus on important matters. (2) I have been in board meetings where it seemed that the subtleties of the issues we dealt with escaped the awareness of a number of the members. 
Functioning as a group - (1) Board members don't say one thing in private and another thing in public. (2) I rarely disagree openly with other members in board meetings.

Exercising authority - (1) The board is always involved in decisions that are important to the future of education in our school. (2) The board will often persuade the school administrator to change his mind about recommendations.

Connecting to the community - (1) Before reaching a decision on important issues, this board usually requests input from persons likely to be affected by the decision. (2) At times this board has appeared unaware of the impact its decisions will have within our service community.

Working toward board improvement - (1) This board periodically sets aside time to learn more about important issues facing schools like the one we govern. (2) This board relies on the natural emergence of leaders rather than trying explicitly to cultivate future leaders for the board.

Acting strategically - (1) This board is more involved in trying to put out fires than in preparing for the future. (2) The board sets clear organizational priorities for the year ahead.

Validity.

Each of the 73 survey items relates to one of the Six Competencies for Effective School Boards. Validity was established by Smoley (1999) through extensive interviews with school board members, expert consultants, and researchers. This study also included the ratings of board effectiveness by school administrators to alleviate the potential bias 
of self-reporting by members themselves (Chait, Holland, and Taylor, 1996). Content validity was established during and after the instrument development (Smoley, 1999) through triangulation of responses from the written accounts of researchers, the accounts of school district consultants, and the accounts of school board members themselves.

\section{Reliability.}

The BSAQ reliability was established by Holland, Chait and Taylor (1989). Their reliability tests with Likert-type scales revealed consistency in all six questionnaire themes demonstrating that the underlying framework is useful and trustworthy for studying board effectiveness. Recognizing that the assumption of reliability was a limitation in this study due to the use of the instrument in the new setting of Christian School boards, the researcher retested the reliability of the BSAQ in the context of this study. Chronbach's alpha coefficients measuring internal consistency of Smoley's (1999) themes are listed in Table 3.

Table 3.

Reliability Coefficients of Six Board Activities (Chronbach's Alpha)

\begin{tabular}{lrrr}
\hline & $\begin{array}{r}\text { Holland, Chait } \\
\text { and Taylor }\end{array}$ & $\begin{array}{c}\text { Christian } \\
\text { Schools }\end{array}$ & Difference \\
\hline & & & \\
Making decisions & $a=.46$ & $a=.66$ & +.20 \\
Functioning as a group & $a=.68$ & $a=.89$ & +.21 \\
Exercising authority & $a=.74$ & $a=.87$ & +.13 \\
Connecting to the community & $a=.70$ & $a=.93$ & +.23 \\
Working toward board improvement & $a=.74$ & $a=.85$ & +.11 \\
Acting strategically & $a=.74$ & $a=.93$ & +.19 \\
\hline
\end{tabular}


These alpha levels are all statistically significant in accordance with the threshold set by Davies et al. (1999) where a factor load of 0.3 or above indicates a substantial link between items within a factor.

\section{Data Collection.}

The BSAQ was administered online using Survey Monkey ${ }^{\mathrm{TM}}$ software. Hyperlinks were sent to participants in the latter part of October 2008 with a four week completion deadline. The instrument was accompanied by an email (see Appendix B) from the researcher encouraging participation in the study. Email reminders were sent to the school administrators at weekly intervals to increase participation rates. School administrators were encouraged to pass on these reminders to their board members since individual board member email addresses are not public information. Participants were assured that their individual responses would not be discernable in the published results.

\section{Variables.}

The dependent variable used in this study was the BSAQ score obtained in accordance with Smoley's (1999) scoring rubric. In the survey, respondents chose one of four responses (strongly agree, agree, disagree, or strongly disagree) that represented their experiences as a member of their school board. Responses were scored from zero to three. Some questions, as identified by Smoley (1999), were reverse scored. For comparison purposes, the average response of "agree" was calculated as a "2". Smoley's (1999) conceptual framework considers "agree" or " 2 " to be the model response score. The independent variables used in this study included the demographic categories from the survey as well as role on the school board. 


\section{Data Analysis Procedures}

The BSAQ survey recorded responses on a four point Likert-type scale that lent itself easily to quantitative analysis of the data (Bourque and Fielder, 2003). The Statistical Package for Social Sciences ${ }^{\mathrm{TM}}$ (SPSS) software was used to execute accurate and efficient exploratory data analysis and statistical analyses for this study.

To answer the first and second research questions, descriptive statistical analyses were employed. Measures of central tendency and cross tabulations were used to provide a graphical representation of the sample and relationships between various demographic categories and scores by board role.

To answer the third research question, correlations of the degree of association between independent variables and between variables as well as a one-way analysis of variance (ANOVA) was performed to ascertain if there were statistically significant differences between scores by role on the school board.

To answer the fourth research question, the researcher had hoped to use multiple regression analyses to measure the level of statistical significance of independent variables predicting variation in the dependent variable. The final sample size of 217, however, did not meet the threshold required $(\mathrm{N}=300)$ for conducting multiple regression analyses (Tabachnick, 2007).

\section{Limitations}

There were a number of limitations inherent in this study. First, it is assumed that Smoley's (1999) survey is a valid and reliable instrument based on the work of his contemporaries. To control for this limitation, the researcher re-tested the reliability of the instrument (see Table 3) to ensure that it was appropriate for application in the new 
setting of Christian School boards. A second limitation was based on the assumption that not all Christian School board members understand or embrace the principle purpose of each individual Christian school to the same degree. While this may be the case, the focus of this study was on board actions, not commitment to the foundational values of the institution. Third, the use of the survey in a cross-sectional manner inhibits the generalizability of results. This limitation was mediated by the fact the study did not intend to create a longitudinal view. Rather, in light of the limited research on Christian School boards, this study provided a basis for future studies. Fourth, it is to be noted that respondents who are aware of current recommendations for school board improvement may have recognized their board as following these prescriptions regardless of actual performance (Cornforth, 2001). This means that board members who were familiar with current research on school board effectiveness responded to each item in light of the ideal board member actions as opposed to the real actions currently taking place. Finally, selection bias could be argued since the participants of the study (school board members and administrators from parent-controlled CSI schools in five Midwest states) were purposefully chosen by the researcher. The researcher chose to include only parentcontrolled schools in order to remove the potential intervening variables of differences between parent-controlled Christian schools and church-controlled (parochial) Christian schools. Selection bias was reduced by the fact that the sample is somewhat representative of the population of CSI schools and the results are thus useful for other schools with similar populations. 


\section{Delimitations}

Since this is the first study of its kind, it is essential to note that it was delimited to create clear results and a foundation for future research. Participants were limited to school board members and school administrators in the upper Midwest. The researcher acknowledges that the input of school employees and the greater constituency would have been a valuable addition. This input, however, would be more manageable in a study focused on a few individual schools rather than a nationwide organization of schools.

\section{Ethics}

The researcher took care to make the purpose of the study clear to all participants. The introductory email reminded participants that their participation was completely voluntary and their names were not collected anywhere on the survey form. Participants were not required to engage in any data collection beyond the survey itself. Results were conveyed to each school board, regardless of the individual board's level of participation, in such a manner that no participant was able to be individually identified.

This research study, a required program element for the Doctor of Philosophy at Iowa State University, was also reviewed and approved by the Institutional Review Board. Forms filed with the Institutional Review Board at Iowa State University are included in Appendix C.

\section{Summary}

After many years of reform, school boards are starting to be recognized as important links in improving school performance (Glass, 2001). This study revealed the 
perceived effectiveness of Christian School boards and provides guidance for improving board leadership and, perhaps ultimately, organizational and student performance. 


\section{Chapter Four: Results}

The purpose of this study was to measure the effectiveness of Christian School boards. The goal was to identify characteristics and factors that contribute to board effectiveness as measured by Smoley's (1999) Board Self-Assessment Questionnaire (BSAQ). The survey questions were designed to address the six elements of effective board actions identified by Smoley (1999) in his conceptual Model for Board Effectiveness: (1) making decisions, (2) functioning as a group, (3) exercising authority, (4) connecting to the community, (5) working toward board improvement, and (6) acting strategically. Demographic items were included to provide general information about Christian School board members. An additional constructed response item was included at the end of the questionnaire to provide respondents the opportunity to share any additional thoughts or insights about Christian School board effectiveness.

\section{Participants}

Previous studies of board effectiveness relied on input from selected participants or viewers of the board. Some studies relied solely on the chief executive officer (CEO) (Bradshaw et al., 1992); others combined scores of board members and CEOs (Green and Griesinger, 1996), while other studies relied on information from just a single member of each board (Cornforth, 2001). In an effort to ensure valid results in this study, input was solicited from all the members of the school board: board members, board presidents, and school administrators.

All 50 CSI schools in Nebraska, Iowa, South Dakota, Minnesota, and Wisconsin were invited to participate in this study. Thirteen schools chose not to participate. The data included in this study were gathered from the remaining 37 schools that chose to 
participate. This population included 393 possible participants: 41 school administrators, 40 board presidents, and 312 school board members. Two hundred seventeen $(\mathrm{N}=217)$ responses were received for a response rate of 55.22 percent. Table 4 displays the respondents by role on the school board.

Table 4.

Respondent Breakdown by School Board Role (N=217)

\begin{tabular}{lcc}
\hline $\begin{array}{l}\text { School Board } \\
\text { Role }\end{array}$ & $\begin{array}{c}\text { Number of } \\
\text { Responses }\end{array}$ & $\begin{array}{c}\text { Valid } \\
\text { Percent }\end{array}$ \\
\hline Board Member & & \\
Board President & 155 & 71.4 \\
School Administrator & 24 & 11.1 \\
\hline
\end{tabular}

*Note: One school has three administrators working with the board

Table 5 displays the disaggregated respondents by school. The school administrator for each board responded in all but one case for a 97 percent response rate. The sample includes the board president in nearly two out of every three schools $(65 \%)$. The mean response rate for board members was 36 percent.

Table 5.

Respondent Breakdown by School and School Board Role (N=217)

\begin{tabular}{lccccc}
\hline & $\begin{array}{r}\text { Total } \\
\text { School* }\end{array}$ & $\begin{array}{r}\text { Board } \\
\text { Members }\end{array}$ & $\begin{array}{c}\text { Board } \\
\text { President }\end{array}$ & $\begin{array}{c}\text { School } \\
\text { Admin. }\end{array}$ & $\begin{array}{c}\text { Response } \\
\text { Rate (\%) }\end{array}$ \\
\hline 1 & 10 & 7 & 1 & 1 & 90.00 \\
2 & 13 & 6 & 1 & 1 & 61.54 \\
3 & 11 & 7 & 1 & 1 & 81.82 \\
4 & 13 & 6 & 1 & 1 & 61.54 \\
5 & 8 & 2 & 0 & 1 & 37.50 \\
6 & 10 & 3 & 1 & 1 & 50.00 \\
7 & 11 & 3 & 0 & 1 & 36.36 \\
8 & 10 & 0 & 0 & 1 & 10.00 \\
9 & 8 & 0 & 0 & 1 & 12.50 \\
*Note: School names are not included in order to protect the anonymity of respondents
\end{tabular}


Table 5. (continued)

\begin{tabular}{|c|c|c|c|c|c|}
\hline \multirow[b]{2}{*}{ School* } & \multirow[b]{2}{*}{$\begin{array}{r}\text { Total } \\
\text { Members }\end{array}$} & \multicolumn{3}{|c|}{ Member Responses } & \multirow[b]{2}{*}{$\begin{array}{l}\text { Response } \\
\text { Rate }(\%)\end{array}$} \\
\hline & & $\begin{array}{r}\text { Board } \\
\text { Member }\end{array}$ & $\begin{array}{r}\text { Board } \\
\text { President }\end{array}$ & $\begin{array}{l}\text { School } \\
\text { Admin. }\end{array}$ & \\
\hline 10 & 6 & 0 & 0 & 1 & 16.67 \\
\hline 11 & 11 & 8 & 1 & 1 & 90.91 \\
\hline 12 & 8 & 2 & 0 & 1 & 37.50 \\
\hline 13 & 7 & 0 & 0 & 1 & 14.29 \\
\hline 14 & 8 & 3 & 0 & 1 & 50.00 \\
\hline 15 & 10 & 6 & 1 & 1 & 80.00 \\
\hline 16 & 9 & 3 & 1 & 1 & 55.56 \\
\hline 17 & 10 & 1 & 1 & 1 & 70.00 \\
\hline 18 & 6 & 2 & 1 & 1 & 66.67 \\
\hline 19 & 8 & 2 & 0 & 1 & 37.50 \\
\hline 20 & 11 & 5 & 1 & 1 & 76.92 \\
\hline 21 & 10 & 5 & 1 & 0 & 60.00 \\
\hline 22 & 13 & 8 & 1 & 1 & 76.92 \\
\hline 23 & 14 & 5 & 1 & 1 & 50.00 \\
\hline 24 & 15 & 11 & 1 & 1 & 86.67 \\
\hline 25 & 10 & 0 & 0 & 1 & 10.00 \\
\hline 26 & 10 & 2 & 0 & 1 & 30.00 \\
\hline 27 & 11 & 3 & 0 & 1 & 36.36 \\
\hline 28 & 9 & 1 & 0 & 1 & 22.22 \\
\hline 29 & 10 & 4 & 1 & 1 & 60.00 \\
\hline 30 & 10 & 5 & 1 & 1 & 70.00 \\
\hline 31 & 13 & 9 & 1 & 1 & 84.62 \\
\hline 32 & 18 & 8 & 1 & 3 & 66.67 \\
\hline 33 & 14 & 5 & 1 & 1 & 50.00 \\
\hline 34 & 10 & 4 & 1 & 1 & 60.00 \\
\hline 35 & 8 & 4 & 1 & 1 & 75.00 \\
\hline 36 & 11 & 3 & 1 & 1 & 45.46 \\
\hline 37 & 19 & 8 & 1 & 1 & 52.63 \\
\hline Total & 393 & 155 & 24 & 38 & 55.22 \\
\hline
\end{tabular}




\section{Research Questions}

The overarching question guiding this study was: How effective are the actions of Christian School boards? The following questions guided the study of this broader question:

1. What are the background characteristics of Christian School board members?

2. What patterns exist in the Christian School board effectiveness ratings of school board members, presidents, and school administrators?

3. Are there mean differences between the ratings of Christian School board members, presidents, and school administrators?

4. What are some of the factors (e.g. role on the board, school characteristics, and board member characteristics) that predict school board effectiveness ratings?

The answers to these four questions constitute the remainder of this chapter. Since the research questions include differentiation of roles on the school board, information is disaggregated by role on the board as appropriate.

Question 1: What are the Background Characteristics of Christian School Board Members?

\section{School demographics.}

Respondents represent three different organizational structures in the Christian Schools surveyed. Table 6 shows a consistent response rate across the grade levels served by the schools surveyed as well as by the board role of respondents. Elementary schools represent 64.5 percent of the sample, secondary schools 16.1 percent, and preschool-12 (PK-12) schools 19.4 percent. For CSI schools in the United States, 51.9 percent are elementary schools, 26.1 percent serve grades PK-12, and 22.0 percent are secondary 
schools. Board members, board presidents, and school administrators in this study are proportionately represented in each 'grades served' group.

Table 6 .

Respondent Breakdown by Grades Served

\begin{tabular}{llcccc}
\hline $\begin{array}{l}\text { Grades } \\
\text { Served }\end{array}$ & & $\begin{array}{r}\text { Board } \\
\text { Member }\end{array}$ & $\begin{array}{r}\text { Board } \\
\text { President }\end{array}$ & $\begin{array}{c}\text { School } \\
\text { Admin. }\end{array}$ & Total \\
\hline K-8 & Count & 98 & 16 & & \\
& \% within Grades & $70.0 \%$ & $11.4 \%$ & $18.6 \%$ & 140 \\
& \% within Role & $63.2 \%$ & $66.7 \%$ & $68.4 \%$ & $64.5 \%$ \\
& \% of Total & $45.2 \%$ & $7.4 \%$ & $12.0 \%$ & $64.5 \%$ \\
& & & & & \\
$9-12$ & Count & 27 & 4 & 4 & 35 \\
& \% within Grades & $77.1 \%$ & $11.4 \%$ & $11.4 \%$ & $100.0 \%$ \\
& \% within Role & $17.4 \%$ & $16.7 \%$ & $10.5 \%$ & $16.1 \%$ \\
& \% of Total & $12.4 \%$ & $1.8 \%$ & $1.8 \%$ & $16.1 \%$ \\
& & & & & \\
PK-12 & Count & 30 & 4 & 8 & 42 \\
& \% within Grades & $71.4 \%$ & $9.5 \%$ & $19.0 \%$ & $100.0 \%$ \\
& \% within Role & $19.4 \%$ & $16.7 \%$ & $21.1 \%$ & $19.4 \%$ \\
& \% of Total & $13.8 \%$ & $1.8 \%$ & $3.7 \%$ & $19.4 \%$ \\
& & & & & \\
Total & Count & 155 & 24 & 38 & 217 \\
& \% within Grades & $71.4 \%$ & $11.1 \%$ & $17.5 \%$ & $100.0 \%$ \\
& \% within Role & $100.0 \%$ & $100.0 \%$ & $100.0 \%$ & $100.0 \%$ \\
& \% of Total & $71.4 \%$ & $11.1 \%$ & $17.5 \%$ & $100.0 \%$ \\
\hline
\end{tabular}

Table 7 displays the geographic location of respondents. The percentage within role for each state and role is consistent throughout. This demonstrates a balanced crosssectional view of the population under study. One exception can be found in the percentage within role of school administrators in South Dakota. This item is slightly higher due to a school with multiple administrators on the board. 
Table 7.

Respondent Breakdown by Location

\begin{tabular}{|c|c|c|c|c|c|}
\hline Location & & $\begin{array}{r}\text { Board } \\
\text { Member }\end{array}$ & $\begin{array}{r}\text { Board } \\
\text { President }\end{array}$ & $\begin{array}{l}\text { School } \\
\text { Admin. }\end{array}$ & Total \\
\hline \multirow[t]{4}{*}{ Iowa } & Count & 86 & 14 & 18 & 118 \\
\hline & $\%$ within Location & $72.9 \%$ & $11.9 \%$ & $15.3 \%$ & $100.0 \%$ \\
\hline & $\%$ within Role & $55.5 \%$ & $58.3 \%$ & $47.4 \%$ & $54.4 \%$ \\
\hline & $\%$ of Total & $39.6 \%$ & $6.5 \%$ & $8.3 \%$ & $54.4 \%$ \\
\hline \multirow[t]{4}{*}{ Minnesota } & Count & 37 & 5 & 9 & 51 \\
\hline & $\%$ within Location & $72.5 \%$ & $9.8 \%$ & $17.6 \%$ & $100.0 \%$ \\
\hline & $\%$ within Role & $23.9 \%$ & $20.8 \%$ & $23.7 \%$ & $23.5 \%$ \\
\hline & $\%$ of Total & $17.1 \%$ & $2.3 \%$ & $4.1 \%$ & $23.5 \%$ \\
\hline \multirow[t]{4}{*}{ South Dakota } & Count & 30 & 4 & 8 & 42 \\
\hline & $\%$ within Location & $61.5 \%$ & $7.7 \%$ & $30.8 \%$ & $100.0 \%$ \\
\hline & $\%$ within Role & $5.2 \%$ & $4.2 \%$ & $10.5 \%$ & $6.0 \%$ \\
\hline & $\%$ of Total & $3.7 \%$ & $0.5 \%$ & $1.8 \%$ & $6.0 \%$ \\
\hline \multirow[t]{4}{*}{ Wisconsin } & Count & 24 & 4 & 7 & 35 \\
\hline & $\%$ within Location & $68.6 \%$ & $11.4 \%$ & $20.0 \%$ & $100.0 \%$ \\
\hline & \% within Role & $15.5 \%$ & $16.7 \%$ & $18.4 \%$ & $16.1 \%$ \\
\hline & $\%$ of Total & $11.1 \%$ & $1.8 \%$ & $3.2 \%$ & $16.1 \%$ \\
\hline \multirow[t]{4}{*}{ Total } & Count & 155 & 24 & 38 & 217 \\
\hline & $\%$ within Location & $71.4 \%$ & $11.1 \%$ & $17.5 \%$ & $100.0 \%$ \\
\hline & $\%$ within Role & $100.0 \%$ & $100.0 \%$ & $100.0 \%$ & $100.0 \%$ \\
\hline & $\%$ of Total & $71.4 \%$ & $11.1 \%$ & $17.5 \%$ & $100.0 \%$ \\
\hline
\end{tabular}

Table 8 displays the number of survey respondents grouped according to school enrollment. Each category of enrollment represents 20-29 percent of the full survey population. This balanced response rate adds validity to the results due to the fact that schools of all sizes of the intended audience were represented in similar proportions. These results are a fair representation of the target population as approximately 50 percent of CSI schools in the United States have enrollments under 200 students. 
Table 8.

Respondent Breakdown by School Size

\begin{tabular}{lrr}
\hline $\begin{array}{l}\text { Student } \\
\text { Enrollment }\end{array}$ & $\begin{array}{c}\text { Number of } \\
\text { Responses }\end{array}$ & $\begin{array}{c}\text { Valid } \\
\text { Percent }\end{array}$ \\
\hline & & \\
less than 100 & 45 & 20.7 \\
$100-199$ & 60 & 27.6 \\
$200-299$ & 50 & 23.0 \\
300 or more & 62 & 28.6 \\
\hline
\end{tabular}

The schools participating in this study are largely found in less-populated locations. More than half of the respondents, 53.0 percent, serve schools in communities with a population of 5,000 or less persons. A little less than one-third of respondents, 30.4 percent, serve schools in communities of five to twenty thousand people and 16.6 percent are in communities larger than 21,000 persons (See Table 9). As CSI does not collect data on school settings, no comparisons are available.

Table 9.

Respondent Breakdown by Setting

\begin{tabular}{lrc}
\hline Setting & $\begin{array}{c}\text { Number of } \\
\text { Responses }\end{array}$ & $\begin{array}{c}\text { Valid } \\
\text { Percent }\end{array}$ \\
\hline $\begin{array}{c}\text { Rural/Small Town } \\
(5,000 \text { or less })\end{array}$ & 115 & 53.0 \\
$\begin{array}{c}\text { Small City } \\
(5,001-20,000)\end{array}$ & 66 & 30.4 \\
$\begin{array}{c}\text { Larger City } \\
(21,000+)\end{array}$ & 36 & 16.6 \\
\hline
\end{tabular}

Participant demographics.

Demographic results are compared to a National School Boards Association survey (Hess, 2002) of public school board members. While the purpose of this study was not to compare public and Christian School boards, the Hess (2002) survey and this 
Christian School board survey include some similar items. In turn, comparisons may be helpful for interpreting the data at hand and looking ahead to implications for future research.

The initial term of service for most Christian School board members is three years. Some schools allow this term to be renewed, while others have a waiting period before members can serve a second term. Table 10 displays the years of service of each study participant.

The short length of terms for Christian School board members as well as the unrenewable term clauses in some Christian School board policies is reflected in the data for years of service on the board. The lack of experience of board members is revealed by the fact that 40.8 percent of board members have served for less than two years. Compare this to the national survey of public school boards (Hess, 2002) where only 10.6 percent of board members had served less than two years.

The percentage of members serving two to five years is similar as 49.7 percent of Christian School board members are in this category compared to 41.0 percent as reported by Hess (2002) in public schools. The higher percentage for Christian Schools is not surprising since, in many cases, the third year of service is the final year for many members due to term limits of three years. Public school boards have more experience, with 48.3 percent serving in their sixth year or more whereas only 9.5 percent in Christian Schools are in their sixth year of service or more. 
Table 10.

Service Year on the School Board

\begin{tabular}{|c|c|c|c|c|c|}
\hline $\begin{array}{l}\text { Year of } \\
\text { Service }\end{array}$ & & $\begin{array}{r}\text { Board } \\
\text { Member }\end{array}$ & $\begin{array}{r}\text { Board } \\
\text { President }\end{array}$ & $\begin{array}{l}\text { School } \\
\text { Admin. }\end{array}$ & Total \\
\hline \multirow[t]{4}{*}{$1^{\text {st }}$ year } & Count & 30 & 1 & 6 & 37 \\
\hline & $\%$ within Service & $81.1 \%$ & $2.7 \%$ & $16.2 \%$ & $100.0 \%$ \\
\hline & $\%$ within Role & $19.4 \%$ & $4.2 \%$ & $16.2 \%$ & $17.1 \%$ \\
\hline & $\%$ of Total & $13.9 \%$ & $0.5 \%$ & $2.8 \%$ & $17.1 \%$ \\
\hline \multirow[t]{4}{*}{$2^{\text {nd }}$ year } & Count & 41 & 1 & 2 & 44 \\
\hline & $\%$ within Service & $93.2 \%$ & $2.3 \%$ & $4.5 \%$ & $100.0 \%$ \\
\hline & $\%$ within Role & $26.5 \%$ & $4.2 \%$ & $5.4 \%$ & $20.4 \%$ \\
\hline & $\%$ of Total & $19.0 \%$ & $0.5 \%$ & $0.9 \%$ & $20.4 \%$ \\
\hline \multirow[t]{4}{*}{$3^{\text {rd }}$ year } & Count & 46 & 10 & 2 & 58 \\
\hline & $\%$ within Service & 79.31 & $17.2 \%$ & $3.4 \%$ & $100.0 \%$ \\
\hline & $\%$ within Role & $29.7 \%$ & $41.7 \%$ & $5.4 \%$ & $26.9 \%$ \\
\hline & $\%$ of Total & $21.3 \%$ & $4.6 \%$ & $0.9 \%$ & $26.9 \%$ \\
\hline \multirow[t]{4}{*}{$4^{\text {th }}$ year } & Count & 23 & 3 & 4 & 30 \\
\hline & $\%$ within Service & $76.7 \%$ & $10.0 \%$ & $13.3 \%$ & $100.0 \%$ \\
\hline & $\%$ within Role & $14.8 \%$ & $12.5 \%$ & $10.8 \%$ & $13.9 \%$ \\
\hline & $\%$ of Total & $10.6 \%$ & $1.4 \%$ & $1.9 \%$ & $13.9 \%$ \\
\hline \multirow[t]{4}{*}{$5^{\text {th }}$ year } & Count & 6 & 1 & 2 & 9 \\
\hline & $\%$ within Service & $66.7 \%$ & $11.1 \%$ & $22.2 \%$ & $100.0 \%$ \\
\hline & $\%$ within Role & $3.9 \%$ & $4.2 \%$ & $5.4 \%$ & $4.2 \%$ \\
\hline & $\%$ of Total & $2.8 \%$ & $0.5 \%$ & $0.9 \%$ & $4.2 \%$ \\
\hline \multirow{4}{*}{$\begin{array}{l}6^{\text {th }} \text { year } \\
\text { or more }\end{array}$} & Count & 9 & 8 & 21 & 28 \\
\hline & $\%$ within Service & $23.7 \%$ & $21.1 \%$ & $55.3 \%$ & $100.0 \%$ \\
\hline & $\%$ within Role & $5.8 \%$ & $33.3 \%$ & $56.8 \%$ & $13.9 \%$ \\
\hline & $\%$ of Total & $4.2 \%$ & $3.7 \%$ & $9.7 \%$ & $13.9 \%$ \\
\hline \multirow[t]{4}{*}{ Total } & Count & 155 & 24 & 37 & 216 \\
\hline & $\%$ within Service & $71.8 \%$ & $11.1 \%$ & $17.1 \%$ & $100.0 \%$ \\
\hline & $\%$ within Role & $100.0 \%$ & $100.0 \%$ & $100.0 \%$ & $100.0 \%$ \\
\hline & $\%$ of Total & $71.8 \%$ & $11.1 \%$ & $17.5 \%$ & $100.0 \%$ \\
\hline
\end{tabular}


Christian School board member ages are listed in Table 11. The age range of school administrators has the widest margin, 20-60 or older, whereas the age range of board members and board presidents ranges from 30-60 or older. The percentages represented in each group are comparable.

Table 11.

Age of Christian School Board Members

\begin{tabular}{|c|c|c|c|c|c|}
\hline Age & & $\begin{array}{r}\text { Board } \\
\text { Member }\end{array}$ & $\begin{array}{r}\text { Board } \\
\text { President }\end{array}$ & $\begin{array}{l}\text { School } \\
\text { Admin. }\end{array}$ & Total \\
\hline \multirow[t]{4}{*}{$20-29$} & Count & 0 & 0 & 2 & 2 \\
\hline & $\%$ within Age & $0.0 \%$ & $0.0 \%$ & $100.0 \%$ & $100.0 \%$ \\
\hline & $\%$ within Role & $0.0 \%$ & $0.0 \%$ & $5.3 \%$ & $0.9 \%$ \\
\hline & $\%$ of Total & $0.0 \%$ & $0.0 \%$ & $0.9 \%$ & $0.9 \%$ \\
\hline \multirow[t]{4}{*}{$30-39$} & Count & 55 & 6 & 9 & 70 \\
\hline & $\%$ within Age & $78.6 \%$ & $8.6 \%$ & $12.9 \%$ & $100.0 \%$ \\
\hline & $\%$ within Role & $35.5 \%$ & $25.0 \%$ & $23.7 \%$ & $32.3 \%$ \\
\hline & $\%$ of Total & $25.3 \%$ & $2.8 \%$ & $4.1 \%$ & $32.3 \%$ \\
\hline \multirow[t]{4}{*}{$40-49$} & Count & 70 & 12 & 11 & 93 \\
\hline & $\%$ within Age & $75.3 \%$ & $12.9 \%$ & $11.8 \%$ & $100.0 \%$ \\
\hline & $\%$ within Role & $45.2 \%$ & $50.0 \%$ & $28.9 \%$ & $42.9 \%$ \\
\hline & $\%$ of Total & $32.3 \%$ & $5.5 \%$ & $5.1 \%$ & $42.9 \%$ \\
\hline \multirow[t]{4}{*}{$50-59$} & Count & 26 & 4 & 12 & 42 \\
\hline & $\%$ within Age & $61.9 \%$ & $9.5 \%$ & $28.6 \%$ & $100.0 \%$ \\
\hline & $\%$ within Role & $16.8 \%$ & $16.7 \%$ & $31.6 \%$ & $19.4 \%$ \\
\hline & $\%$ of Total & $12.0 \%$ & $1.8 \%$ & $5.5 \%$ & $19.4 \%$ \\
\hline \multirow[t]{4}{*}{60 or older } & Count & 4 & 2 & 4 & 10 \\
\hline & $\%$ within Age & $40.0 \%$ & $20.0 \%$ & $40.0 \%$ & $100.0 \%$ \\
\hline & $\%$ within Role & $2.6 \%$ & $8.3 \%$ & $10.5 \%$ & $4.6 \%$ \\
\hline & $\%$ of Total & $1.8 \%$ & $0.9 \%$ & $1.8 \%$ & $4.6 \%$ \\
\hline \multirow[t]{4}{*}{ Total } & Count & 155 & 24 & 38 & 217 \\
\hline & $\%$ within Age & $71.4 \%$ & $11.1 \%$ & $17.5 \%$ & $100.0 \%$ \\
\hline & $\%$ within Role & $100.0 \%$ & $100.0 \%$ & $100.0 \%$ & $100.0 \%$ \\
\hline & $\%$ of Total & $71.4 \%$ & $11.1 \%$ & $17.5 \%$ & $100.0 \%$ \\
\hline
\end{tabular}


The majority of Christian School board members (79.9\%) are between the ages of 30-49. This stands in comparison to the report by Hess (2002) that found that the majority of public school board members (73.9\%) are between the ages of 40-59. In addition, while one-fifth of public school board members (20.3\%) are age 60 or older, only 3.4 percent of Christian School board members are age 60 or older. It could be argued that the online format of the Christian School board survey could have lowered the response rate from older board members due to lack of computer skills and/or Internet access. On the other hand, all respondents were given the option of completing a hard copy of the survey that was made available to them.

The gender of school board members by role is listed in Table 12. It is evident that women are severely underrepresented on the school board, as 72.3 percent of school board members are men and 100 percent of school board presidents are men. The breakdown of school administrators is similar to that of school board members. Male school administrators comprise 78.9 percent of respondents and females 23.5 percent. Of the 23.5 percent of female school administrators, all are serving in K-8 schools. There are no female high school administrators in the survey sample.

Three out of four $(76.0 \%)$ board members in Christian Schools are male as compared to 61.1 percent male in the Hess (2002) study. This wide disparity of gender on Christian School boards as well as the nonexistence of female high school principals could possibly be linked to the lack of egalitarian gender beliefs in the supporting church community. The fact that 24 percent of board members are female is likely an improvement compared to 20 years ago when many schools did not allow women to serve as board members. During this same time, many churches have also become more 
open to allowing women to serve in leadership positions. Unfortunately, although the door has been opened to female board members, the lack of female leadership beyond grades K-8 or on the board itself is troubling. Up until this study, no data have been collected on demographic information about Christian School board members, so no comparisons are available within CSI.

Table 12.

Gender of Christian School Board Members

\begin{tabular}{|c|c|c|c|c|c|}
\hline Gender & & $\begin{array}{r}\text { Board } \\
\text { Member }\end{array}$ & $\begin{array}{r}\text { Board } \\
\text { President } \\
\end{array}$ & $\begin{array}{l}\text { School } \\
\text { Admin. }\end{array}$ & Total \\
\hline \multirow[t]{4}{*}{ Male } & Count & 112 & 24 & 30 & 166 \\
\hline & $\%$ within Gender & $67.5 \%$ & $14.5 \%$ & $18.1 \%$ & $100.0 \%$ \\
\hline & \% within Role & $72.3 \%$ & $100.0 \%$ & $78.9 \%$ & $76.5 \%$ \\
\hline & $\%$ of Total & $51.6 \%$ & $11.1 \%$ & $13.8 \%$ & $76.5 \%$ \\
\hline \multirow[t]{4}{*}{ Female } & Count & 43 & 0 & 8 & 51 \\
\hline & $\%$ within Gender & $84.3 \%$ & $0.0 \%$ & $15.7 \%$ & $100.0 \%$ \\
\hline & \% within Role & $27.7 \%$ & $0.0 \%$ & $21.1 \%$ & $23.5 \%$ \\
\hline & $\%$ of Total & $19.8 \%$ & $0.0 \%$ & $3.7 \%$ & $23.5 \%$ \\
\hline \multirow[t]{4}{*}{ Total } & Count & 155 & 24 & 38 & 217 \\
\hline & $\%$ within Age & $71.4 \%$ & $11.1 \%$ & $17.5 \%$ & $100.0 \%$ \\
\hline & $\%$ within Role & $100.0 \%$ & $100.0 \%$ & $100.0 \%$ & $100.0 \%$ \\
\hline & $\%$ of Total & $71.4 \%$ & $11.1 \%$ & $17.5 \%$ & $100.0 \%$ \\
\hline
\end{tabular}

The ethnicity of respondents is outlined in Table 13. An overwhelming majority of Christian School board members are White, with less than 1 percent being non-White. The White, Dutch ancestry of many of the Christian Schools in this study is reflected very strongly in the racial makeup of each school board. It is to be recognized that public school districts as reported by Hess (2002) are also mostly White at a rate of 85.5 percent. In comparison, the Christian School board survey respondents are an astounding 99.4 
percent White. While this may show solidarity to the primarily Dutch background of the founders and ancestors in these school systems, it is questionable that this is an equivalent representation of the ethnic diversity that continues to increase in many Christian Schools.

Table 13.

Race of Christian School Board Members

\begin{tabular}{|c|c|c|c|c|c|}
\hline Race & & $\begin{array}{r}\text { Board } \\
\text { Member }\end{array}$ & $\begin{array}{r}\text { Board } \\
\text { President }\end{array}$ & $\begin{array}{l}\text { School } \\
\text { Admin. }\end{array}$ & Total \\
\hline \multirow[t]{4}{*}{ White } & Count & 153 & 24 & 36 & 213 \\
\hline & $\%$ within Race & $71.8 \%$ & $11.3 \%$ & $16.9 \%$ & $100.0 \%$ \\
\hline & $\%$ within Role & $99.4 \%$ & $100.0 \%$ & $97.3 \%$ & $99.1 \%$ \\
\hline & $\%$ of Total & $71.2 \%$ & $11.2 \%$ & $16.7 \%$ & $99.1 \%$ \\
\hline \multirow[t]{4}{*}{ Hispanic } & Count & 0 & 0 & 1 & 1 \\
\hline & $\%$ within Race & $0.0 \%$ & $0.0 \%$ & $100.0 \%$ & $100.0 \%$ \\
\hline & $\%$ within Role & $0.0 \%$ & $0.0 \%$ & $2.7 \%$ & $0.5 \%$ \\
\hline & $\%$ of Total & $0.0 \%$ & $0.0 \%$ & $0.5 \%$ & $0.5 \%$ \\
\hline \multirow[t]{4}{*}{ Other } & Count & 1 & 0 & 0 & 1 \\
\hline & $\%$ within Race & $100.0 \%$ & $0.0 \%$ & $0.0 \%$ & $100.0 \%$ \\
\hline & $\%$ within Role & $0.6 \%$ & $0.0 \%$ & $0.0 \%$ & $0.5 \%$ \\
\hline & $\%$ of Total & $0.5 \%$ & $0.0 \%$ & $0.0 \%$ & $0.5 \%$ \\
\hline \multirow[t]{4}{*}{ Total* } & Count & 154 & 24 & 37 & $215 *$ \\
\hline & $\%$ within Race & $71.6 \%$ & $11.2 \%$ & $17.2 \%$ & $100.0 \%$ \\
\hline & $\%$ within Role & $100.0 \%$ & $100.0 \%$ & $100.0 \%$ & $100.0 \%$ \\
\hline & $\%$ of Total & $71.6 \%$ & $11.2 \%$ & $17.2 \%$ & $100.0 \%$ \\
\hline
\end{tabular}

*2 respondents did not indicate race

The school board survey also included a question for respondents to indicate their current occupational status. School board members come from a wider variety of backgrounds than board presidents (See Table 14).

Christian School board members come largely from business and/or professional backgrounds $(66.5 \%)$. This is compared to their public school counterparts at 44.6 percent. The connection to age of board members is also revealed in the professional 
Table 14.

Professional Background of Christian School Board Members

\begin{tabular}{|c|c|c|c|c|c|}
\hline $\begin{array}{l}\text { Professional } \\
\text { Background }\end{array}$ & & $\begin{array}{r}\text { Board } \\
\text { Member }\end{array}$ & $\begin{array}{r}\text { Board } \\
\text { President }\end{array}$ & $\begin{array}{l}\text { School } \\
\text { Admin. }\end{array}$ & Total \\
\hline Unknown & $\begin{array}{l}\text { Count } \\
\% \text { within Pro.Bkd. } \\
\% \text { within Role } \\
\% \text { of Total }\end{array}$ & $\begin{array}{l}0 \\
0.0 \% \\
0.0 \% \\
0.0 \%\end{array}$ & $\begin{array}{l}0 \\
0.0 \% \\
0.0 \% \\
0.0 \%\end{array}$ & $\begin{array}{r}2 \\
100.0 \% \\
5.3 \% \\
0.9 \%\end{array}$ & $\begin{array}{r}2 \\
100.0 \% \\
0.9 \% \\
0.9 \%\end{array}$ \\
\hline Education & $\begin{array}{l}\text { Count } \\
\% \text { within Pro.Bkd. } \\
\% \text { within Role } \\
\% \text { of Total }\end{array}$ & $\begin{array}{l}21 \\
37.5 \% \\
13.5 \% \\
9.7 \%\end{array}$ & $\begin{array}{l}0 \\
0.0 \% \\
0.0 \% \\
0.0 \%\end{array}$ & $\begin{array}{l}35 \\
62.5 \% \\
92.1 \% \\
16.1 \%\end{array}$ & $\begin{array}{c}56 \\
100.0 \% \\
25.8 \% \\
25.8 \%\end{array}$ \\
\hline $\begin{array}{l}\text { Homemaker/ } \\
\text { Retired }\end{array}$ & $\begin{array}{l}\text { Count } \\
\% \text { within Pro.Bkd. } \\
\% \text { within Role } \\
\% \text { of Total }\end{array}$ & $\begin{array}{r}4 \\
100.0 \% \\
2.6 \% \\
1.8 \%\end{array}$ & $\begin{array}{l}0 \\
0.0 \% \\
0.0 \% \\
0.0 \%\end{array}$ & $\begin{array}{l}0 \\
0.0 \% \\
0.0 \% \\
0.0 \%\end{array}$ & $\begin{array}{r}4 \\
100.0 \% \\
1.8 \% \\
1.8 \%\end{array}$ \\
\hline $\begin{array}{l}\text { Non-Profit/ } \\
\text { Government }\end{array}$ & $\begin{array}{l}\text { Count } \\
\% \text { within Pro.Bkd. } \\
\% \text { within Role } \\
\% \text { of Total }\end{array}$ & $\begin{array}{c}6 \\
85.70 \% \\
3.9 \% \\
2.8 \%\end{array}$ & $\begin{array}{r}1 \\
14.3 \% \\
4.2 \% \\
0.5 \%\end{array}$ & $\begin{array}{l}0 \\
0.0 \% \\
0.0 \% \\
0.0 \%\end{array}$ & $\begin{array}{r}7 \\
100.0 \% \\
3.2 \% \\
3.2 \%\end{array}$ \\
\hline $\begin{array}{l}\text { Business/ } \\
\text { Professional }\end{array}$ & $\begin{array}{l}\text { Count } \\
\% \text { within Pro.Bkd. } \\
\% \text { within Role } \\
\% \text { of Total }\end{array}$ & $\begin{array}{l}100 \\
83.3 \% \\
64.5 \% \\
46.1 \%\end{array}$ & $\begin{array}{l}19 \\
15.8 \% \\
79.2 \% \\
8.8 \%\end{array}$ & $\begin{array}{l}1 \\
0.8 \% \\
2.6 \% \\
0.5 \%\end{array}$ & $\begin{array}{r}120 \\
100.0 \% \\
55.3 \% \\
55.3 \%\end{array}$ \\
\hline Other & $\begin{array}{l}\text { Count } \\
\% \text { within Pro.Bkd. } \\
\% \text { within Role } \\
\% \text { of Total }\end{array}$ & $\begin{array}{l}24 \\
85.7 \% \\
15.5 \% \\
11.1 \%\end{array}$ & $\begin{array}{c}4 \\
14.3 \% \\
16.7 \% \\
1.8 \%\end{array}$ & $\begin{array}{l}0 \\
0.0 \% \\
0.0 \% \\
0.0 \%\end{array}$ & $\begin{array}{l}28 \\
100.0 \% \\
12.9 \% \\
12.9 \%\end{array}$ \\
\hline Total & $\begin{array}{l}\text { Count } \\
\% \text { within Pro.Bkd. } \\
\% \text { within Role } \\
\% \text { of Total }\end{array}$ & $\begin{array}{r}155 \\
71.4 \% \\
100.0 \% \\
71.4 \%\end{array}$ & $\begin{array}{r}24 \\
11.1 \% \\
100.0 \% \\
11.1 \%\end{array}$ & $\begin{array}{r}38 \\
17.5 \% \\
100.0 \% \\
17.5 \%\end{array}$ & $\begin{array}{l}217 \\
100.0 \% \\
100.0 \% \\
100.0 \%\end{array}$ \\
\hline
\end{tabular}


background category by the percent of retired board members. The younger Christian School boards have 2.2 percent of its membership who are retired or homemakers as compared to public school boards with 26.2 percent of members in the same category.

The level of education for Christian School board members varies greatly across roles. Not surprisingly, school administrators are the most highly educated members of the board with 78.9 percent possessing graduate/advanced degrees. This speaks to the necessity of an advanced degree in obtaining an administrative license in many states. For board members and board presidents, 10.6 percent report their highest level of education as high school graduate or GED. Slightly more than one-fourth (27.2\%) have had some post high school training whereas 44.7 percent of members have at least a four-year college degree. Board presidents, on the other hand, tend to be more highly educated then board members. Two-thirds of presidents have at least a four-year college degree as opposed to a little more than half of board members. As a whole, it is evident that Christian School boards are quite well-educated with only 10.6 percent of respondents having no post-high school training (See Table 15).

In this survey, 87.2 percent of respondents have had some level of college training. This is comparable to the Hess (2002) study where more than 90 percent of members had similar levels of training. It is interesting to note that in both this study and the one completed by Hess (2002), there is a positive correlation between the level of education of the board members and the size of the school or district. 
Table 15.

Level of Education of Christian School Board Members

\begin{tabular}{|c|c|c|c|c|c|}
\hline $\begin{array}{l}\text { Level of } \\
\text { Education }\end{array}$ & & $\begin{array}{r}\text { Board } \\
\text { Member }\end{array}$ & $\begin{array}{r}\text { Board } \\
\text { President }\end{array}$ & $\begin{array}{l}\text { School } \\
\text { Admin. }\end{array}$ & Total \\
\hline $\begin{array}{l}\text { H.S Grad./ } \\
\text { GED }\end{array}$ & $\begin{array}{l}\text { Count } \\
\% \text { within Educ. } \\
\% \text { within Role } \\
\% \text { of Total }\end{array}$ & $\begin{array}{r}21 \\
91.3 \% \\
13.5 \% \\
9.7 \%\end{array}$ & $\begin{array}{l}2 \\
8.7 \% \\
8.3 \% \\
0.9 \%\end{array}$ & $\begin{array}{l}0 \\
0.0 \% \\
0.0 \% \\
0.0 \%\end{array}$ & $\begin{array}{l}23 \\
100.0 \% \\
10.6 \% \\
10.6 \%\end{array}$ \\
\hline $\begin{array}{l}\text { Some College/ } \\
\text { Post H.S. Train./ } \\
\text { 2-yr. degree }\end{array}$ & $\begin{array}{l}\text { Count } \\
\% \text { within Educ. } \\
\% \text { within Role } \\
\% \text { of Total }\end{array}$ & $\begin{array}{l}53 \\
88.3 \% \\
34.2 \% \\
24.4 \%\end{array}$ & $\begin{array}{c}6 \\
10.0 \% \\
25.0 \% \\
2.8 \%\end{array}$ & $\begin{array}{l}1 \\
1.7 \% \\
2.6 \% \\
0.5 \%\end{array}$ & $\begin{array}{c}60 \\
100.0 \% \\
27.6 \% \\
27.6 \%\end{array}$ \\
\hline $\begin{array}{l}\text { Four-year } \\
\text { College degree }\end{array}$ & $\begin{array}{l}\text { Count } \\
\% \text { within Educ. } \\
\% \text { within Role } \\
\% \text { of Total }\end{array}$ & $\begin{array}{l}49 \\
74.2 \% \\
31.6 \% \\
22.6 \%\end{array}$ & $\begin{array}{l}10 \\
15.2 \% \\
41.7 \% \\
4.6 \%\end{array}$ & $\begin{array}{l}7 \\
10.6 \% \\
18.4 \% \\
3.2 \%\end{array}$ & $\begin{array}{l}66 \\
100.0 \% \\
30.4 \% \\
30.4 \%\end{array}$ \\
\hline $\begin{array}{l}\text { Graduate/ } \\
\text { Advanced degree }\end{array}$ & $\begin{array}{l}\text { Count } \\
\% \text { within Educ. } \\
\% \text { within Role } \\
\% \text { of Total }\end{array}$ & $\begin{array}{l}32 \\
47.1 \% \\
20.6 \% \\
14.7 \%\end{array}$ & $\begin{array}{r}6 \\
8.8 \% \\
25.0 \% \\
2.8 \%\end{array}$ & $\begin{array}{l}30 \\
44.1 \% \\
78.9 \% \\
13.8 \%\end{array}$ & $\begin{array}{r}68 \\
100.0 \% \\
31.3 \% \\
31.3 \%\end{array}$ \\
\hline Total & $\begin{array}{l}\text { Count } \\
\% \text { within Educ. } \\
\% \text { within Role } \\
\% \text { of Total }\end{array}$ & $\begin{array}{r}155 \\
71.4 \% \\
100.0 \% \\
71.4 \%\end{array}$ & $\begin{array}{r}24 \\
11.1 \% \\
100.0 \% \\
11.1 \%\end{array}$ & $\begin{array}{r}38 \\
17.5 \% \\
100.0 \% \\
17.5 \%\end{array}$ & $\begin{array}{l}217 \\
100.0 \% \\
100.0 \% \\
100.0 \%\end{array}$ \\
\hline
\end{tabular}

Eight out of ten $(80.2 \%)$ Christian School board members have children or grandchildren attending the school in which they serve. By role, almost nine out of ten $(88.4 \%)$ board members have children or grandchildren in school compared to 75.0 percent of presidents and 50.0 percent of administrators.

\section{School board characteristics.}

Three quarters of boards $(75.5 \%)$ spend 10 or less hours per month in meetings. In regard to how time is spent in meetings, 40.8 percent report that no time is devoted to 
professional development directed toward the board, 25.5 percent report devoting 30 minutes or less per month to development, 21.4 percent spend one hour per month on professional development, and 12.8 percent spend more than one hour per month.

As it relates to the item "Please indicate your best guess about the percent of the students in your school that can be expected to achieve at or above grade level," 90.7 percent report that at least 70 percent of the students can be expected to achieve at or above grade level with 45.6 percent expecting 90 percent or more students to be at or above grade level (See Table 16).

Table 16.

Board Member Expectations of Percentage of Students that can Achieve at or above Grade Level

\begin{tabular}{lrr}
\hline $\begin{array}{l}\text { Percentage at or } \\
\text { above grade level }\end{array}$ & $\begin{array}{r}\text { Number of } \\
\text { Responses }\end{array}$ & $\begin{array}{r}\text { Valid } \\
\text { Percent }\end{array}$ \\
\hline Less than $70 \%$ & & \\
$70-79 \%$ & 20 & 9.3 \\
$80-89 \%$ & 34 & 15.8 \\
$90-94 \%$ & 63 & 29.3 \\
$95-100 \%$ & 60 & 27.9 \\
Total & 38 & 17.7 \\
\hline
\end{tabular}

Respondents also indicated the percent of meeting time spent on discussing the improvement of student learning. The vast majority (96.5\%) of respondents report spending less than half of their time discussing the improvement of student learning. Roughly half $(54.5 \%)$ of the boards spend $10-25$ percent of meeting time on student learning and one-fourth $(24.7 \%)$ spend less than ten percent of meeting time on student learning (See Table 17). No questions were asked regarding what other items boards spend time on during their meetings. 
Table 17.

Percentage of Board Meeting Time Spent on Discussing Student Achievement by Role

\begin{tabular}{|c|c|c|c|c|c|}
\hline $\begin{array}{l}\text { Percent of } \\
\text { Meeting Time }\end{array}$ & & $\begin{array}{r}\text { Board } \\
\text { Member }\end{array}$ & $\begin{array}{r}\text { Board } \\
\text { President } \\
\end{array}$ & $\begin{array}{l}\text { School } \\
\text { Admin. }\end{array}$ & Total \\
\hline \multirow[t]{4}{*}{ Less than $10 \%$} & Count & 30 & 5 & 16 & 51 \\
\hline & $\%$ within Time & $58.8 \%$ & $9.8 \%$ & $31.4 \%$ & $100.0 \%$ \\
\hline & $\%$ within Role & $20.8 \%$ & $20.8 \%$ & $42.1 \%$ & $24.8 \%$ \\
\hline & $\%$ of Total & $14.6 \%$ & $2.4 \%$ & $7.8 \%$ & $24.8 \%$ \\
\hline \multirow[t]{4}{*}{$10-19 \%$} & Count & 41 & 7 & 8 & 56 \\
\hline & $\%$ within Time & $73.2 \%$ & $12.5 \%$ & $14.3 \%$ & $100.0 \%$ \\
\hline & $\%$ within Role & $28.5 \%$ & $29.2 \%$ & $21.1 \%$ & $27.2 \%$ \\
\hline & $\%$ of Total & $19.9 \%$ & $3.4 \%$ & $3.9 \%$ & $27.2 \%$ \\
\hline \multirow[t]{4}{*}{$20-29 \%$} & Count & 39 & 8 & 9 & 56 \\
\hline & $\%$ within Time & $69.6 \%$ & $14.3 \%$ & $16.1 \%$ & $100.0 \%$ \\
\hline & $\%$ within Role & $27.1 \%$ & $33.3 \%$ & $23.7 \%$ & $27.2 \%$ \\
\hline & $\%$ of Total & $18.9 \%$ & $3.9 \%$ & $4.4 \%$ & $27.2 \%$ \\
\hline \multirow[t]{4}{*}{$30-50 \%$} & Count & 30 & 3 & 3 & 36 \\
\hline & $\%$ within Time & $83.3 \%$ & $8.3 \%$ & $8.3 \%$ & $100.0 \%$ \\
\hline & $\%$ within Role & $20.8 \%$ & $12.5 \%$ & $7.9 \%$ & $17.5 \%$ \\
\hline & $\%$ of Total & $14.6 \%$ & $1.5 \%$ & $1.5 \%$ & $17.5 \%$ \\
\hline \multirow[t]{4}{*}{ More than $50 \%$} & Count & 4 & 1 & 2 & 7 \\
\hline & $\%$ within Time & $57.1 \%$ & $14.3 \%$ & $28.6 \%$ & $100.0 \%$ \\
\hline & $\%$ within Role & $2.8 \%$ & $4.2 \%$ & $5.3 \%$ & $3.4 \%$ \\
\hline & $\%$ of Total & $1.9 \%$ & $0.5 \%$ & $1.0 \%$ & $3.4 \%$ \\
\hline \multirow[t]{4}{*}{ Total } & Count & 144 & 24 & 38 & 206 \\
\hline & $\%$ within Educ. & $69.9 \%$ & $11.7 \%$ & $18.4 \%$ & $100.0 \%$ \\
\hline & $\%$ within Role & $100.0 \%$ & $100.0 \%$ & $100.0 \%$ & $100.0 \%$ \\
\hline & $\%$ of Total & $69.9 \%$ & $11.7 \%$ & $18.4 \%$ & $100.0 \%$ \\
\hline
\end{tabular}

Question 2: What Patterns Exist in the Christian School Board Effectiveness Ratings of School Board Members, Presidents, and School Administrators?

In all but one of the six board activities of Smoley's conceptual model, the participants in this study scored below the model response level. Making rational decisions was the only category where participants scored above the model board mean. 
(As outlined in chapter two, the response of "agree" or "2" is the model response score for each individual statement). In order to determine which differences were statistically significant, $t$-tests were run for each area of board activity. Results revealed that four of the five activity scores were lower at statistically significant levels $(p \leq .05)$. Table 18 outlines the descriptive statistics of respondent scores in each board activity.

Table 18.

Descriptive Statistics of Board Governance Activities Scores

\begin{tabular}{|c|c|c|c|c|c|}
\hline $\begin{array}{l}\text { Board } \\
\text { Activity }\end{array}$ & $\begin{array}{r}\mathrm{M} \\
\text { (Model) }\end{array}$ & $\begin{array}{r}\mathrm{M} \\
\text { (Sample) } \\
\end{array}$ & $\begin{array}{r}\text { Mean } \\
\text { Difference } \\
\end{array}$ & SD & $p$ \\
\hline Making decisions & 26 & 26.898 & 0.898 & 3.168 & $.000 *$ \\
\hline Functioning as a group & 24 & 22.040 & -1.960 & 6.059 & $.000^{*}$ \\
\hline Exercising authority & 24 & 20.043 & -3.957 & 5.301 & $.000 *$ \\
\hline $\begin{array}{l}\text { Connecting to } \\
\text { the community }\end{array}$ & 24 & 23.791 & -0.209 & 6.710 & .667 \\
\hline $\begin{array}{l}\text { Working toward } \\
\text { board improvement }\end{array}$ & 24 & 16.071 & -7.929 & 5.348 & $.000^{*}$ \\
\hline Acting strategically & 24 & 21.225 & -2.775 & 6.674 & $.000 *$ \\
\hline
\end{tabular}

${ }^{*} p<.05$

Disaggregated scores by board role show that school administrator ratings are higher than those of school board members in all six activities. This means administrators perceive their boards as being more effective than board members do. School board president ratings, as well, are higher than those of school board members in all areas. This consistent discrepancy reveals that the leadership of the board, president and administrator, perceive the board as more effective that the board perceives itself. Table 19 outlines the descriptive statistics of overall board activity ratings by role. 
Table 19.

Descriptive Statistics of Board Governance Activities Scores by Board Role

\begin{tabular}{lcc}
\hline Board Activity & M & SD \\
\hline Making decisions & & \\
Member & 26.737 & 3.116 \\
President & 26.826 & 3.298 \\
$\quad$ Administrator & 27.645 & 3.292 \\
Functioning as a group & & \\
Member & 21.461 & 6.813 \\
President & 24.000 & 3.899 \\
Administrator & 23.135 & 2.859 \\
Exercising authority & & \\
Member & 19.481 & 6.115 \\
President & 21.957 & 2.011 \\
Administrator & 20.969 & 1.750 \\
Connecting to the community & & \\
Member & 23.268 & 7.464 \\
President & 25.409 & 4.020 \\
Administrator & 24.968 & 3.851 \\
Working toward board improvement & & \\
Member & 15.015 & 5.569 \\
President & 18.435 & 3.788 \\
Administrator & 18.867 & 3.608 \\
Acting strategically & & \\
Member & 21.008 & 7.341 \\
President & 22.667 & 4.487 \\
Administrator & 21.182 & 5.434 \\
\hline
\end{tabular}

Open ended question responses

The final question on the Christian School Board Survey invited respondents to answer the following open ended question: "Is there anything else you would like to share about Christian School board effectiveness?” Forty-one respondents $(22.9 \%)$ responded to this question. The majority of the responses related to at least one of the six themes of Smoley's (1999) Model for Board Effectiveness as reported in the upcoming sections of this chapter. 


\section{Making decisions}

Table 20 outlines the mean and standard deviation scores for each survey statement related to making decisions. Scores are also disaggregated by board role.

Table 20.

Descriptive Statistics of Making Decisions

\begin{tabular}{lrrrr}
\hline & & \multicolumn{3}{c}{ Disaggregated by School Board Role } \\
Making rational decisions & Aggregate & Member & President & Admin. \\
& M (SD) & M (SD) & M (SD) & M (SD) \\
\hline
\end{tabular}

This board works to reach

$\begin{array}{lllll}\text { consensus on important matters. } & 2.66(.50) & 2.58(.53) & 2.83(.39) & 2.90(.30)\end{array}$

*I have been in board meetings $\quad 1.58(.69) \quad 1.59(.72) \quad 1.52(.67) \quad 1.55(.57)$ where it seemed that the subtleties of the issues we dealt with escaped the awareness of a number of members.

$\begin{array}{lllll}\text { Our board explicitly examines } & 2.23(.50) & 2.23(.49) & 2.17(.49) & 2.26(.58)\end{array}$ the "downside" or possible pitfalls of any important decision it is about to make.

\begin{tabular}{|c|c|c|c|c|}
\hline $\begin{array}{l}* \text { Many of the issue that the board } \\
\text { deals with seem to be separate } \\
\text { tasks, unrelated to each other. }\end{array}$ & $1.76(.56)$ & $1.79(.54)$ & $1.78(.60)$ & $1.64(.61)$ \\
\hline $\begin{array}{l}\text { The decisions of this board on } \\
\text { one issue tend to influence what } \\
\text { we do about other issues that } \\
\text { come before us. }\end{array}$ & $1.81(.53)$ & $1.80(.51)$ & $1.65(.65)$ & $1.94(.51)$ \\
\hline $\begin{array}{l}\text { *This board's decisions usually } \\
\text { result in a split vote. }\end{array}$ & $2.42(.56)$ & $2.38(.52)$ & $2.43(.73)$ & $2.58(.56)$ \\
\hline
\end{tabular}


Table 20. (continued)

\begin{tabular}{|c|c|c|c|c|}
\hline \multirow[b]{2}{*}{ Making rational decisions } & \multirow[b]{2}{*}{$\begin{array}{r}\text { Aggregate } \\
\mathrm{M}(\mathrm{SD}) \\
\end{array}$} & \multicolumn{3}{|c|}{ Disaggregated by School Board Role } \\
\hline & & $\begin{array}{r}\text { Member } \\
\text { M (SD) }\end{array}$ & $\begin{array}{r}\text { President } \\
\text { M (SD) }\end{array}$ & $\begin{array}{l}\text { Admin } \\
\text { M (SD) }\end{array}$ \\
\hline $\begin{array}{l}\text { When faced with an important } \\
\text { issue, the board often } \\
\text { "brainstorms" and tries to } \\
\text { generate a whole list of creative } \\
\text { approaches or solutions to this } \\
\text { problem. }\end{array}$ & $1.98(.54)$ & $1.93(.54)$ & $2.00(.43)$ & $2.16(.58)$ \\
\hline $\begin{array}{l}\text { *A certain group of board } \\
\text { members will usually vote } \\
\text { together for or against particular } \\
\text { issues. }\end{array}$ & $2.11(.58)$ & $2.08(.56)$ & $2.30(.56)$ & $2.10(.65)$ \\
\hline $\begin{array}{l}\text { The board often requests that } \\
\text { a decision be postponed until } \\
\text { further information can be } \\
\text { obtained. }\end{array}$ & $1.88(.57)$ & $1.89(.52)$ & $1.87(.55)$ & $1.87(.81)$ \\
\hline $\begin{array}{l}\text { The board usually receives a } \\
\text { full rationale for the } \\
\text { recommendations it is asked } \\
\text { to act upon. }\end{array}$ & $2.05(.52)$ & $2.06(.53)$ & $2.00(.43)$ & $2.06(.51)$ \\
\hline $\begin{array}{l}\text { *This board tries to avoid } \\
\text { issues that are ambiguous or } \\
\text { complicated. }\end{array}$ & $2.03(.50)$ & $2.05(.45)$ & $1.91(.60)$ & $2.00(.63)$ \\
\hline $\begin{array}{l}\text { This board spends a lot of time } \\
\text { listening to different points of } \\
\text { view before it votes on an } \\
\text { important matter. }\end{array}$ & $2.13(.50)$ & $2.09(.51)$ & $2.7(.39)$ & $2.26(.51)$ \\
\hline $\begin{array}{l}\text { All board members support } \\
\text { majority decisions. }\end{array}$ & $2.26(.58)$ & $2.26(.59)$ & $2.17(.58)$ & $2.32(.54)$ \\
\hline
\end{tabular}


Results from the Christian School board survey revealed that board members, board presidents, and school administrators significantly exceed the standard set forth by Smoley (1999) for making rational decisions in the Model for Effective School Boards. Smoley (1999) lists four indicative actions of boards that engage in making rational decisions: (1) access and use relevant information, (2) discuss deliberately, (3) consider alternative actions, and (4) work toward consensus. Within the activity of making decisions, there were a few areas where all respondents showed remarkable solidarity. For the question "This board works to reach consensus on important matters," a staggering 99.0 percent of respondents agreed with this statement. This level of unity was also shown when respondents rated how well the board examines the downside or pitfalls of important decisions (90.7 percent in agreement).

Survey results indicate that the majority of Christian School boards take care to use information that is interconnected to multiple issues. Members report that, when faced with important issues, time is taken to brainstorm unique approaches, while also working decisively toward a consensus decision that all members can support publicly after the meeting. While consensus is an unmistakable hallmark of Christian School boards, it is also to be noted that split-votes do not occur very often. This is evidenced by 93.1 percent of respondents disagreeing that "this board's decisions usually result in a split vote." It could be assumed that this is a mark of how well boards discuss different views before coming to a decision and calling for a final vote. Alternately, it is also possible that this is a mark of board members who lack commitment to the school.

The high scores in making rational decisions for Christian School board members reflects their diligence in using input toward serving their constituency well. This is 
evidenced by 84.4 percent of respondents agreeing with the survey statement that "before reaching a decision on important issues, this board usually requests input from persons likely affected by the decision." In this manner, there is congruity between the expectations of the constituency and ensuing board policies and programs.

Open-ended responses confirmed the high level of decision making by Christian School boards. Five responses attributed the high level of decision making and consensus to the collaborative work accomplished at the committee level.

\section{Functioning as a group}

Table 21 outlines the mean and standard deviation scores for each survey statement related to functioning as a group. Scores are also disaggregated by board role.

Table 21.

Descriptive Statistics of Functioning as a Group

\begin{tabular}{|c|c|c|c|c|}
\hline \multirow[b]{2}{*}{ Functioning as a Group } & \multirow[b]{2}{*}{$\begin{array}{r}\text { Aggregate } \\
\text { M (SD) }\end{array}$} & \multicolumn{3}{|c|}{ Disaggregated by School Board Role } \\
\hline & & $\begin{array}{r}\text { Member } \\
\text { M (SD) }\end{array}$ & $\begin{array}{r}\text { President } \\
\mathrm{M}(\mathrm{SD}) \\
\end{array}$ & $\begin{array}{l}\text { Admin. } \\
\mathrm{M}(\mathrm{SD})\end{array}$ \\
\hline $\begin{array}{l}\text { There have been occasions } \\
\text { where the board itself has } \\
\text { acted in way inconsistent } \\
\text { with the school's deepest values. }\end{array}$ & $0.56(.63)$ & $0.53(.59)$ & $0.43(.60)$ & $0.78(.76)$ \\
\hline $\begin{array}{l}\text { Board members don't say } \\
\text { one thing in private and } \\
\text { another in public. }\end{array}$ & $1.99(.77)$ & $1.98(.82)$ & $2.05(.74)$ & $2.03(.61)$ \\
\hline $\begin{array}{l}\text { *I rarely disagree openly with } \\
\text { other members in board meetings. }\end{array}$ & $1.47(.72)$ & $1.46(.72)$ & $1.43(.68)$ & $1.50(.74)$ \\
\hline $\begin{array}{l}\text { At our board meetings, there is } \\
\text { at least as much dialogue among } \\
\text { members as there is between } \\
\text { members and administrators. }\end{array}$ & $1.99(.72)$ & $1.91(.74)$ & $2.29(.64)$ & $2.14(.64)$ \\
\hline
\end{tabular}


Table 21. (continued)

\begin{tabular}{|c|c|c|c|c|}
\hline \multirow[b]{2}{*}{ Functioning as a Group } & \multirow[b]{2}{*}{$\begin{array}{r}\text { Aggregate } \\
\text { M (SD) }\end{array}$} & \multicolumn{3}{|c|}{ Disaggregated by School Board Role } \\
\hline & & $\begin{array}{r}\text { Member } \\
\mathrm{M}(\mathrm{SD})\end{array}$ & $\begin{array}{r}\text { President } \\
\mathrm{M}(\mathrm{SD})\end{array}$ & $\begin{array}{l}\text { Admin. } \\
\mathrm{M}(\mathrm{SD})\end{array}$ \\
\hline $\begin{array}{l}\text { The leadership of this board } \\
\text { typically goes out of its way to } \\
\text { make sure that all members } \\
\text { have the same information on } \\
\text { important issues. }\end{array}$ & $2.09(.78)$ & $2.00(.83)$ & $2.43(.51)$ & $2.25(.60)$ \\
\hline $\begin{array}{l}\text { The board has adopted some } \\
\text { explicit goals for itself, distinct } \\
\text { from goals it has for the total } \\
\text { school. }\end{array}$ & $1.46(.82)$ & $1.39(.82)$ & $1.86(.73)$ & $1.53(.84)$ \\
\hline $\begin{array}{l}\text { Board members are consistently } \\
\text { able to hold confidential items } \\
\text { in confidence. }\end{array}$ & $2.03(.73)$ & $2.04(.79)$ & $2.14(.48)$ & $1.89(.62)$ \\
\hline $\begin{array}{l}\text { I have been present in board } \\
\text { meetings where discussions } \\
\text { of the values of the school were } \\
\text { key factors in reaching a } \\
\text { conclusion on a problem. }\end{array}$ & $2.13(.71)$ & $2.06(.76)$ & $2.29(.56)$ & $2.31(.58)$ \\
\hline $\begin{array}{l}\text { I am able to speak my mind } \\
\text { on key issues without fear } \\
\text { that I will be ostracized by } \\
\text { some members of this board. }\end{array}$ & $2.20(.80)$ & $2.09(.86)$ & $2.52(.51)$ & $2.42(.60)$ \\
\hline $\begin{array}{l}\text { *Values are seldom discussed } \\
\text { explicitly at our board meetings. }\end{array}$ & 2.01(.79) & $1.96(.83)$ & $2.19(.68)$ & $2.06(.63)$ \\
\hline $\begin{array}{l}\text { Once a decision is made, all } \\
\text { board members work together } \\
\text { to see that it is accepted and } \\
\text { carried out. }\end{array}$ & $2.11(.76)$ & $2.06(.83)$ & $2.19(.60)$ & $2.28(.51)$ \\
\hline $\begin{array}{l}* \text { Members of this board are } \\
\text { sometimes disrespectful in } \\
\text { their comments to other } \\
\text { board members. }\end{array}$ & $2.29(.83)$ & $2.21(.89)$ & $2.62(.59)$ & $2.39(.69)$ \\
\hline
\end{tabular}


While Christian School boards perceive themselves to be effective at making decisions, particularly reaching consensus, survey results indicate that their perceptions for how well they function as a group are below the standard of performance as outlined by Smoley (1999) in his Model for Effective School Boards. Although this may appear somewhat contradictory, Smoley's (1999) model lists five indicators of boards that function cohesively as a group that are not necessarily directly connected to making decisions. These indicators of functioning cohesively as a group include: (1) operating within norms, (2) demonstrating leadership, (3) articulating cohesiveness, (4) acting on values, and (5) showing respect.

Respondents indicate that Christian School boards have a very high level of commitment to the values of the school and engage in open communication as they strive to uphold these values. This is evidenced by 82 percent of respondents in agreement or disagreement in 10 of the 12 survey statements about concerning working as a group. On the item "There have been occasions where the board itself has acted in ways inconsistent with the school's deepest values," 93.1 percent of respondents disagreed with this statement. In addition, 91.2 percent agreed that the values of the school are key factors in reaching a conclusion to a problem and 90.3 percent agree that they are able to speak their mind on key issues at board meetings without fear of being ostracized.

Sixteen of the open-ended responses confirmed the importance of acting on shared core values. These were identified as core values of the school specifically and of a broader Reformed worldview of Christian Education in general. As important as these core values are, three respondents indicated that there are board members who are not perceived to be upholding these values at expected levels and their personal agendas are 
detrimental to board effectiveness and overall school climate. Several responses referenced the foundation of the school as rooted in prayer and devotion to God coupled with a firm faith that he will bless all they do as a board. Serving a common Master and Lord is evident in the majority of responses. Responses in this category were initially coded under the umbrella of "core values" and then further delineated in accordance with responses more directly referring to faith-related items. Sample responses are below:

(1) "Our board is encourages collaborative decision making and consistently adheres to the core values of the school and Christian education in general."

(2) "More time should be spent in being involved/visiting the school and also develop a better understanding of the validity of a Christian education. Seeing all education and sports as totally encompassed in God's word as a whole life view."

(3) "Our school board seeks God's guidance through prayer, I also appreciate the fact that we (once per month) share our hearts by giving devotionals.

(4) "We care about each child..we understand that they were created by our Maker..therefore, all are unique and special... and decisions reflect that kind of care of individuals."

(5) "The more prayer...the more effective."

Given the respondents' focus on the importance of values and prayer (outlined in chapter four) as the basis of working together as a group, it is somewhat surprising that the overall score for functioning cohesively as a group is below Smoley's (1999) standard. A deeper look at the individual statements for this section, however, reveals three primary reasons for the lower score. First, respondents indicate that the majority of 
boards do not have explicit goals for itself that are distinct from those of the total school.

Second, Christian School board members strongly disagree with the statement that "there have been occasions where the board itself has acted in ways inconsistent with the school's deepest values." This strong level of disagreement is significantly different than the model score; so much so that the overall score for working together as a group is significantly impacted. The third item that has the effect of pulling down the overall score on working together as a group is the lower than average levels of open disagreement among board members at board meetings.

\section{Exercising authority}

Table 22 outlines the mean and standard deviation scores for each survey statement related to exercising authority. Scores are also disaggregated by board role.

\section{Table 22.}

Descriptive Statistics of Exercising Authority

\begin{tabular}{|c|c|c|c|c|}
\hline \multirow[b]{2}{*}{ Exercising Authority } & \multirow[b]{2}{*}{$\begin{array}{r}\text { Aggregate } \\
\text { M (SD) }\end{array}$} & \multicolumn{3}{|c|}{ Disaggregated by School Board Role } \\
\hline & & $\begin{array}{r}\text { Member } \\
\text { M (SD) }\end{array}$ & $\begin{array}{r}\text { President } \\
\mathrm{M}(\mathrm{SD})\end{array}$ & $\begin{array}{l}\text { Admin. } \\
\text { M (SD) }\end{array}$ \\
\hline $\begin{array}{l}\text { Usually the board and the } \\
\text { school administrator } \\
\text { advocate the same actions. }\end{array}$ & $2.18(.73)$ & $2.14(.80)$ & $2.30(.47)$ & $2.28(.52)$ \\
\hline $\begin{array}{l}\text { The board will sharply question } \\
\text { certain administrative proposals, } \\
\text { requiring the school } \\
\text { administrator to reconsider the } \\
\text { recommendations. }\end{array}$ & $1.09(.65)$ & $1.08(.68)$ & $1.09(.67)$ & $1.13(.55)$ \\
\hline $\begin{array}{l}\text { The board is always involved } \\
\text { in decisions that are important } \\
\text { to the future of education in our } \\
\text { school. }\end{array}$ & $2.22(.80)$ & $2.16(.85)$ & $2.30(.63)$ & $2.41(.67)$ \\
\hline
\end{tabular}


Table 22. (continued)

\begin{tabular}{|c|c|c|c|c|}
\hline \multirow[b]{2}{*}{ Exercising Authority } & \multirow[b]{2}{*}{$\begin{array}{r}\text { Aggregate } \\
\text { M (SD) }\end{array}$} & \multicolumn{3}{|c|}{ Disaggregated by School Board Role } \\
\hline & & $\begin{array}{l}\text { Member } \\
\text { M (SD) }\end{array}$ & $\begin{array}{r}\text { President } \\
\text { M (SD) }\end{array}$ & $\begin{array}{l}\text { Admin. } \\
\text { M (SD) }\end{array}$ \\
\hline $\begin{array}{l}\text { *The board will often persuade } \\
\text { the school administrator to } \\
\text { change his/her mind about } \\
\text { recommendations. }\end{array}$ & $1.97(.64)$ & $1.86(.69)$ & $2.13(.46)$ & $2.25(.44)$ \\
\hline $\begin{array}{l}\text { The board often requests } \\
\text { additional information before } \\
\text { making a decision. }\end{array}$ & $1.82(.67)$ & $1.80(.72)$ & $1.91(.51)$ & $1.84(.57)$ \\
\hline $\begin{array}{l}\text { The board often discusses its } \\
\text { role in school management. }\end{array}$ & $1.52(.68)$ & $1.46(.72)$ & $1.70(.56)$ & $1.66(.60)$ \\
\hline $\begin{array}{l}\text { * Recommendations from the } \\
\text { administration are usually } \\
\text { accepted with little questioning. }\end{array}$ & $1.30(.68)$ & $1.33(.70)$ & $1.34(.57)$ & $1.16(.68)$ \\
\hline $\begin{array}{l}\text { The board president and school } \\
\text { administrator confer so that } \\
\text { differences of opinion are } \\
\text { identified. }\end{array}$ & $1.93(.74)$ & $1.82(.77)$ & $2.43(.51)$ & $2.00(.57)$ \\
\hline $\begin{array}{l}\text { We are not a "rubber stamp" } \\
\text { board. }\end{array}$ & $2.08(.77)$ & $1.98(.83)$ & $2.43(.51)$ & $2.19(.59)$ \\
\hline $\begin{array}{l}\text { This board often acts } \\
\text { independent of the school } \\
\text { administrator's } \\
\text { recommendations. }\end{array}$ & $0.77(.49)$ & $0.80(.47)$ & $0.83(.49)$ & $0.63(.55)$ \\
\hline $\begin{array}{l}\text { The board is outspoken in its } \\
\text { view about programs. }\end{array}$ & $1.44(.67)$ & $1.39(.71)$ & $1.57(.51)$ & $1.56(.56)$ \\
\hline $\begin{array}{l}* \text { The board will reverse its } \\
\text { position based on pressure } \\
\text { from the constituency. }\end{array}$ & $1.73(.70)$ & $1.66(.75)$ & $1.91(.42)$ & $1.88(.61)$ \\
\hline
\end{tabular}


Christian School boards perceive themselves to be below average when it comes to exercising authority. This is a result of varied levels of agreement for survey statements about this board activity. One indicator of exercising authority is how well members act within defined roles (Smoley, 1999). Respondents indicate that the lines of communication are open with balanced input at meetings from all participants. This communication, along with a respect for the leadership of the school administrator, provides a powerful environment for effective boardsmanship.

There were two items where respondents had significantly unified ratings. When asked to rate the item "Usually the board president and school administrator advocate the same actions," 94.0 percent agreed that this was indeed the case. This unified response is reinforced in a similar item where 96.2 percent of respondents disagreed that their board often acts independently of the school administrator's recommendations. Open-ended responses revealed a high level of trust and respect for the school administrator.

Respondents recognize the importance and value of a school administrator who manages the day-to-day operations of the school and also contributes to the leadership of the school board.

Three statements received the less than 60 percent agreement. 58.3 percent of respondents agreed that "recommendations from the administration are usually accepted with little questioning" and only 47.3 percent agree that "the board is outspoken in its view about programs." These results add to the perception that the board has high regard for the work of the school administrator. That being said, it could be argued that this also shows that the board is not exercising an appropriate level of authority by allowing the school administrator to take the lead. Some of this may be attributed to board members 
who do not understand the authority of the board. This lack of understanding is reflected by only 54.5 percent of respondents agreeing that "the board often discusses its role in school management."

Connecting to the community.

Table 23 outlines the mean and standard deviation scores for each survey statement related to connecting to the community. Scores are also disaggregated by board role.

Table 23.

Descriptive Statistics of Connecting to the Community

\begin{tabular}{|c|c|c|c|c|}
\hline \multirow[b]{2}{*}{ Connecting to the Community } & \multirow[b]{2}{*}{$\begin{array}{r}\text { Aggregate } \\
\text { M (SD) }\end{array}$} & \multicolumn{3}{|c|}{ Disaggregated by School Board Role } \\
\hline & & $\begin{array}{l}\text { Member } \\
\text { M (SD) }\end{array}$ & $\begin{array}{r}\text { President } \\
\text { M (SD) }\end{array}$ & $\begin{array}{l}\text { Admin. } \\
\text { M (SD) }\end{array}$ \\
\hline $\begin{array}{l}\text { This board has formal structures } \\
\text { and procedures for involving the } \\
\text { constituency. }\end{array}$ & $2.09(.78)$ & $2.09(.79)$ & $2.23(.75)$ & $2.00(.77)$ \\
\hline $\begin{array}{l}\text { A written report including the } \\
\text { board's activities is periodically } \\
\text { prepared and distributed to the } \\
\text { constituency. }\end{array}$ & $1.97(.90)$ & $1.91(.93)$ & $2.23(.75)$ & $2.10(.83)$ \\
\hline $\begin{array}{l}\text { This board communicates its } \\
\text { decisions to all those who are } \\
\text { affected by them. }\end{array}$ & $2.03(.74)$ & $1.96(.77)$ & $2.18(.66)$ & $2.23(.56)$ \\
\hline $\begin{array}{l}\text { If our board thinks that an } \\
\text { important group of constituents } \\
\text { is likely to disagree with an } \\
\text { action we are considering, we } \\
\text { will make sure we learn how } \\
\text { they feel before we actually } \\
\text { make the decision. }\end{array}$ & $1.86(.72)$ & $1.84(.77)$ & $1.95(.49)$ & $1.87(.62)$ \\
\hline
\end{tabular}


Table 23. (continued)

\begin{tabular}{|c|c|c|c|c|}
\hline \multirow[b]{2}{*}{ Connecting to the Community } & \multirow[b]{2}{*}{$\begin{array}{r}\text { Aggregate } \\
\text { M (SD) }\end{array}$} & \multicolumn{3}{|c|}{ Disaggregated by School Board Role } \\
\hline & & $\begin{array}{r}\text { Member } \\
\text { M (SD) }\end{array}$ & $\begin{array}{r}\text { President } \\
\mathrm{M}(\mathrm{SD})\end{array}$ & $\begin{array}{l}\text { Admin } \\
\text { M (SD) }\end{array}$ \\
\hline $\begin{array}{l}\text { This board and its members } \\
\text { maintain channels of } \\
\text { communication with specific } \\
\text { key constituency leaders. }\end{array}$ & $1.85(.66)$ & $1.82(.71)$ & $1.86(.47)$ & $2.00(.52)$ \\
\hline $\begin{array}{l}\text { This board has formed ad hoc } \\
\text { committees or task forces that } \\
\text { include staff and constituency } \\
\text { representatives as well as } \\
\text { board members. }\end{array}$ & $2.17(.79)$ & $2.12(.84)$ & $2.36(.49)$ & $2.26(.73)$ \\
\hline $\begin{array}{l}\text { This board is as attentive to } \\
\text { how it reaches conclusions as } \\
\text { it is to what is decided. }\end{array}$ & $1.94(.73)$ & $1.92(.76)$ & $2.05(.65)$ & $1.97(.66)$ \\
\hline $\begin{array}{l}\text { I have been in board meetings } \\
\text { where explicit attention was } \\
\text { given to the concerns of the } \\
\text { constituency. }\end{array}$ & $1.99(.70)$ & $1.96(.73)$ & $2.09(.61)$ & $2.10(.60)$ \\
\hline $\begin{array}{l}\text { The board periodically obtains } \\
\text { information on the perspectives } \\
\text { of staff and constituency. }\end{array}$ & $1.94(.69)$ & $1.89(.74)$ & $2.05(.58)$ & $2.13(.50)$ \\
\hline $\begin{array}{l}\text { Before reaching a decision on } \\
\text { important issues, this board } \\
\text { usually requests input from } \\
\text { persons likely affected by the } \\
\text { decision. }\end{array}$ & $1.91(.65)$ & $1.88(.68)$ & $2.05(.49)$ & $1.97(.60)$ \\
\hline $\begin{array}{l}* \text { At times this board has } \\
\text { appeared unaware of the impact } \\
\text { its decisions will have within } \\
\text { our service constituency. }\end{array}$ & $1.84(.72)$ & $1.80(.77)$ & $1.95(.38)$ & $1.94(.68)$ \\
\hline
\end{tabular}


Table 23. (continued)

\begin{tabular}{lcccc}
\hline & $\begin{array}{c}\text { Disaggregated by School Board Role } \\
\text { Aggregate } \\
\text { Connecting to the Community }\end{array}$ & $\begin{array}{c}\text { Member } \\
\text { M (SD) }\end{array}$ & $\begin{array}{c}\text { President } \\
\text { M (SD) }\end{array}$ & $\begin{array}{r}\text { Admin. } \\
\text { M (SD) }\end{array}$ \\
\hline $\begin{array}{l}\text { * The administration rarely } \\
\text { reports to the board on the } \\
\text { concerns of the school it serves. }\end{array}$ & $2.18(.80)$ & $2.09(.85)$ & $2.41(.67)$ & $2.42(.56)$ \\
\hline
\end{tabular}

In the area of connecting to the community, Christian School boards scored slightly below Smoley's (1999) model score for effective school boards, but not at statistically significant levels. Much of this could be attributed to the relative privacy of Christian School board operations. This is not to say that information is withheld from the constituency, rather the proceedings that brought about the decisions are not always divulged since school board meetings are not open to the public. While meetings are closed, the constituency has regular opportunities to give input into school operations. Parents and supporters have ample opportunity to interact with board members at school, church, and community functions.

A low level of variance in responses to the statements in this category indicates that the levels of agreement were between $76-89 \%$ on all twelve statements. Minimal variance reflects a widespread belief that school boards are working fairly effectively with the supporting community.

Reponses to the open-ended question reinforce the perception that Christian School boards are working with the constituents they serve. With the exception of the executive committee of the board, all committees-education, finance, building and grounds, and promotions - include board members as well as members of the 
constituency, faculty, and staff. This arrangement ensures input from the constituency on many school board decisions. As one respondent stated, "The work of committees with constituent and staff members helps to bring consensus." Another respondent attributed board effectiveness to the strong relationship between the staff and the school board and how this relationship is nurtured regularly through formal and informal events. While this may be the case in some schools, one respondent indicated that there was a "lack of buyin from the constituency at large to step up and volunteer to help on a regular basis."

The results of the survey on connecting to the community are surprising given the traditionally close ties within the Christian school constituency. With 80.2 percent of respondents indicating that they have children or grandchildren in the schools they serve, it would be expected that connections would be more evident in the results.

Working toward board improvement

Table 24 outlines the mean and standard deviation scores for each survey statement related to working toward board improvement. Scores are also disaggregated by board role.

Smoley (1999) identified three key indicators of boards that work toward improvement: (1) cultivating leadership, (2) assessing competence, and (3) obtaining assistance. Survey results reveal that Christian School board members rate themselves below Smoley's (1999) model score in all areas of working toward board improvement. Ratings for this category were the least unified of the six categories under study. The highest level of agreement or disagreement on a single item was 79 percent with the remaining responses resulting in agreement or disagreement below 70 percent. In addition, group ratings for all 12 statements were below the model score. 
Table 24.

Descriptive Statistics of Working toward Board Improvement

\begin{tabular}{|c|c|c|c|c|}
\hline & & \multicolumn{3}{|c|}{ Disaggregated by School Board Role } \\
\hline $\begin{array}{l}\text { Working Toward } \\
\text { Board Improvement }\end{array}$ & $\begin{array}{r}\text { Aggregate } \\
\text { M (SD) }\end{array}$ & $\begin{array}{r}\text { Member } \\
\text { M (SD) }\end{array}$ & $\begin{array}{r}\text { President } \\
\text { M (SD) }\end{array}$ & $\begin{array}{l}\text { Admin. } \\
\text { M (SD) }\end{array}$ \\
\hline $\begin{array}{l}\text { I have participated in board } \\
\text { discussions about what we } \\
\text { should do differently as a } \\
\text { result of a mistake the board } \\
\text { made. }\end{array}$ & $1.71(.84)$ & $1.61(.86)$ & $1.96(.77)$ & $1.97(.67)$ \\
\hline $\begin{array}{l}\text { At least once every two years, } \\
\text { our board has a retreat or special } \\
\text { session to examine our } \\
\text { performance, how well we are } \\
\text { doing as a board. }\end{array}$ & $0.98(.74)$ & $0.98(.76)$ & $1.13(.69)$ & $0.90(.71)$ \\
\hline $\begin{array}{l}\text { This board periodically sets } \\
\text { aside time to learn more about } \\
\text { important issues facing schools } \\
\text { like the one we govern. }\end{array}$ & $1.52(.72)$ & $1.49(.74)$ & $1.57(.66)$ & $1.63(.67)$ \\
\hline $\begin{array}{l}* \text { This board relies on the natural } \\
\text { emergence of leaders rather } \\
\text { than trying explicitly to cultivate } \\
\text { future leaders for the board. }\end{array}$ & $1.08(.61)$ & $1.03(.62)$ & $1.09(.60)$ & $1.27(.58)$ \\
\hline $\begin{array}{l}\text { * Most people on this board tend } \\
\text { to rely on observation and } \\
\text { informal discussions to learn } \\
\text { about their roles and } \\
\text { responsibilities. }\end{array}$ & $1.14(.60)$ & $1.09(.61)$ & $1.22(.52)$ & $1.30(.60)$ \\
\hline $\begin{array}{l}\text { When a new member joins this } \\
\text { board, we make sure that } \\
\text { someone serves as a mentor to } \\
\text { help this person learn the ropes. }\end{array}$ & $1.10(.67)$ & $1.00(.63)$ & $1.39(.72)$ & $1.33(.66)$ \\
\hline $\begin{array}{l}\text { I have participated in board } \\
\text { discussions about the } \\
\text { effectiveness of our performance. } \\
\text { *reverse scored }\end{array}$ & $1.52(.75)$ & $1.35(.75)$ & $1.96(.71)$ & $1.90(.48)$ \\
\hline
\end{tabular}


Table 24. (continued)

\begin{tabular}{|c|c|c|c|c|}
\hline & & \multicolumn{3}{|c|}{ Disaggregated by School Board Role } \\
\hline $\begin{array}{l}\text { Working Toward } \\
\text { Board Improvement }\end{array}$ & $\begin{array}{r}\text { Aggregate } \\
\text { M (SD) }\end{array}$ & $\begin{array}{r}\text { Member } \\
\mathrm{M}(\mathrm{SD})\end{array}$ & $\begin{array}{r}\text { President } \\
\mathrm{M}(\mathrm{SD}) \\
\end{array}$ & $\begin{array}{l}\text { Admin. } \\
\mathrm{M}(\mathrm{SD})\end{array}$ \\
\hline $\begin{array}{l}\text { I have participated in } \\
\text { discussions with new } \\
\text { members about the roles } \\
\text { and responsibilities of a } \\
\text { board member. }\end{array}$ & $1.52(.84)$ & $1.31(.76)$ & $2.04(.71)$ & $2.07(.83)$ \\
\hline $\begin{array}{l}\text { This board seeks outside } \\
\text { assistance in considering } \\
\text { its work. }\end{array}$ & $1.60(.67)$ & $1.56(.71)$ & $1.70(.56)$ & $1.70(.53)$ \\
\hline $\begin{array}{l}\text { *I have never received feedback } \\
\text { on my performance as a member } \\
\text { of this board. }\end{array}$ & $1.20(.84)$ & $0.97(.73)$ & $1.48(.79)$ & $1.97(.81)$ \\
\hline $\begin{array}{l}\text { *This board does not allocate } \\
\text { organizational funds for the } \\
\text { purpose of board education } \\
\text { and development. }\end{array}$ & $1.06(.68)$ & $1.07(.69)$ & $1.00(.60)$ & $1.07(.69)$ \\
\hline $\begin{array}{l}\text { This board has conducted an } \\
\text { explicit examination of its } \\
\text { roles and responsibilities. }\end{array}$ & $1.64(.74)$ & $1.56(.77)$ & $1.91(.60)$ & $1.77(.68)$ \\
\hline
\end{tabular}

Christian School boards do not perceive themselves as effectively cultivating leadership. More than three-fourths of respondents (79.2\%), agree that their boards rely on the natural emergence of leaders rather than cultivating future leaders.

Smoley (1999) reported that only 25 percent of boards assess their performance. In this study, 23.1 percent report that their board assesses its performance. Although participation in this study is considered an assessment of board performance, it is assumed that respondents did not consider this when completing the survey. While Smoley (1999) also indicates that many boards engage in informal assessment 
procedures, this is not true for Christian School boards. It is unclear, however, why Christian School boards are lax in the area of self-assessment. Not only do boards rarely organize retreats, they also do not use internal resources of mentoring new members through the expertise of current members. This is evidenced by more than three-fourths of respondents indicating that their boards do not hold a retreat or special session to examine the performance of the board, do not provide mentors to help new members learn the ropes, and do not budget funds specifically for board professional development. Nearly three out of four (72.4\%) respondents indicated that most board members rely on informal discussions and observations to learn about their roles and responsibilities.

It is unclear if boards evaluate their performance holistically or individually; however, 75 percent of board members have never had their individual performance evaluated. A lesser percentage of board presidents (60.9\%) report not being evaluated. Nearly one-third of school administrators, 32.4 percent, report never being evaluated. This is a very high percentage based on the fact that the board's number one responsibility is to hire and evaluate the school administrator. A similar percentage of administrators, 37.8 percent, reported that the board does not ask him/her to articulate his/her vision for the school's future along with strategies to realize that vision.

Approximately 63 percent of Christian School board members report that their boards seek outside assistance. Responses to other questions, however, give the impression that this assistance is quite limited and its long term impact is unknown. Some of the schools surveyed have participated in regional board workshops in the past, but these workshops have not been offered recently due to lack of interest from area school board members. While the workshops do not offer school-specific training, they do 
provide members with the opportunity to network and learn from board members in other schools.

Male and female administrators have different perceptions regarding how prevalent mentorships are for new board members. Sixty three percent of male administrators report that no mentors are provided for new members whereas 100 percent of female administrators report that no mentorships exist for new members. This difference not only reveals the differences in perceptions between male and female administrators, but also may uncover a possible difference between views of the value or need of mentorships.

Jackson and Holland (1998) state that the preservation of or intervention of board training increases how a board views their effectiveness on the BSAQ. Furthermore, a lack of mentorships or other forms of training for new members can inhibit a board's ability to plan strategically for the future (Jackson and Holland, 1998). The connection between board training and strategic planning reveals the importance and interconnectedness of all six activities of effective boards.

\section{Acting strategically}

Table 25 outlines the mean and standard deviation scores for each survey statement related to acting strategically. Scores are also disaggregated by board role. In the final category, Christian School board members again scored below the model rating. Boards which act strategically (1) address critical issues, (2) plan, (3) organize, (4) consider context, and (5) evaluate. Seventy percent of respondents agreed or disagreed with eight of the twelve survey statements. The lowest rating included 46.3 percent agreeing that the subtleties of issues escape the awareness of some board 
members. The highest rating was based on 85.8 percent of all participants disagreeing that their board has evaded important school issues. This result is encouraging, but it is also evident that issues consume so much meeting time that long range plans are often not addressed. In fact, two-thirds of respondents indicated that no time is spent addressing long-term goals.

Table 25.

Descriptive Statistics of Acting Strategically

\begin{tabular}{|c|c|c|c|c|}
\hline \multirow[b]{2}{*}{ Acting Strategically } & \multirow[b]{2}{*}{$\begin{array}{r}\text { Aggregate } \\
\text { M (SD) }\end{array}$} & \multicolumn{3}{|c|}{ Disaggregated by School Board Role } \\
\hline & & $\begin{array}{r}\text { Member } \\
\text { M (SD) }\end{array}$ & $\begin{array}{r}\text { President } \\
\mathrm{M}(\mathrm{SD})\end{array}$ & $\begin{array}{l}\text { Admin. } \\
\text { M (SD) }\end{array}$ \\
\hline $\begin{array}{l}* \text { This board is more involved in } \\
\text { trying to put out fires than in } \\
\text { preparing for the future. }\end{array}$ & $2.01(.81)$ & $1.99(.83)$ & $2.05(.74)$ & $2.06(.79)$ \\
\hline $\begin{array}{l}\text { The board sets clear } \\
\text { organizational priorities for } \\
\text { the year ahead. }\end{array}$ & $1.85(.72)$ & $1.83(.76)$ & $1.95(.50)$ & $1.88(.65)$ \\
\hline $\begin{array}{l}\text { *This board delays action until } \\
\text { an issue becomes urgent or } \\
\text { critical. }\end{array}$ & $1.90(.68)$ & $1.91(.71)$ & $1.95(.67)$ & $1.82(.53)$ \\
\hline $\begin{array}{l}\text { *Our board meetings tend to } \\
\text { focus more on current concerns } \\
\text { than on preparing for the future. }\end{array}$ & $1.44(.70)$ & $1.48(.71)$ & $1.52(.75)$ & $1.21(.60)$ \\
\hline $\begin{array}{l}\text { At least once a year, this board } \\
\text { asks that the school } \\
\text { administrator articulate his/her } \\
\text { vision for the school's future and } \\
\text { strategies to realize that vision. }\end{array}$ & $1.73(.83)$ & $1.68(.83)$ & $2.05(.67)$ & $1.73(.91)$ \\
\hline $\begin{array}{l}\text { *This board has on occasion } \\
\text { evaded responsibility for some } \\
\text { important issue facing the school. }\end{array}$ & $2.03(.82)$ & $2.03(.86)$ & $2.14(.73)$ & $1.97(.68)$ \\
\hline
\end{tabular}

*reverse scored 
Table 25. (continued)

\begin{tabular}{|c|c|c|c|c|}
\hline \multirow[b]{2}{*}{ Acting Strategically } & \multirow[b]{2}{*}{$\begin{array}{r}\text { Aggregate } \\
\text { M (SD) }\end{array}$} & \multicolumn{3}{|c|}{ Disaggregated by School Board Role } \\
\hline & & $\begin{array}{l}\text { Member } \\
\text { M (SD) }\end{array}$ & $\begin{array}{r}\text { President } \\
\text { M (SD) }\end{array}$ & $\begin{array}{l}\text { Admin. } \\
\text { M (SD) }\end{array}$ \\
\hline $\begin{array}{l}\text { This board often discusses where } \\
\text { the school should be headed five } \\
\text { or more years into the future. }\end{array}$ & $1.72(.80)$ & $1.68(.85)$ & $1.90(.70)$ & $1.73(.63)$ \\
\hline $\begin{array}{l}\text { Within the past year, this board } \\
\text { has reviewed the school's } \\
\text { strategies for attaining its } \\
\text { long-term goals. }\end{array}$ & $1.79(.80)$ & $1.77(.83)$ & $1.86(.57)$ & $1.85(.83)$ \\
\hline $\begin{array}{l}\text { I have been in board meetings } \\
\text { where the discussion focused } \\
\text { on identifying or overcoming } \\
\text { the school's weaknesses. }\end{array}$ & $1.81(.65)$ & $1.75(.71)$ & $1.95(.38)$ & $1.94(.50)$ \\
\hline $\begin{array}{l}\text { The board discusses events and } \\
\text { trends in the larger environment } \\
\text { that may present specific } \\
\text { opportunities for this school. }\end{array}$ & $1.90(.67)$ & $1.87(.70)$ & $1.95(.38)$ & $1.97(.68)$ \\
\hline $\begin{array}{l}\text { This board makes explicit use } \\
\text { of the long-range priorities of } \\
\text { this school in dealing with } \\
\text { current issues. }\end{array}$ & $1.82(.73)$ & $1.80(.75)$ & $2.00(.63)$ & $1.76(.71)$ \\
\hline $\begin{array}{l}\text { More than half of this board's } \\
\text { time is spent in discussions of } \\
\text { issues of importance to the } \\
\text { school's long-range future. }\end{array}$ & $1.23(.69)$ & $1.21(.74)$ & $1.33(.56)$ & $1.24(.59)$ \\
\hline
\end{tabular}

Many open-ended responses addressed the inefficiency of board operations. Ten of the forty-one respondents to the open-ended question $(24.4 \%)$ indicated that board meetings get "mired down in too many day to day details." Long range planning is difficult and is "taking a back seat." 
Question 3-Are there Mean Differences between the Ratings of Christian School Board Members, Presidents, and School Administrators?

The respondents in this study, when analyzed as a single group, produced mean scores in five of six activities that were significantly different than Smoley's (1999) model score (see Table 18). In order to determine which individual differences were statistically significant, $t$-tests were run for all 73 items of the BSAQ. Table 26 outlines the number of items with significant mean differences $(p \leq .05)$ as compared to Smoley's (1999) model. Although the distributions for some items were negatively skewed, "the $t$ procedures can be used even for clearly skewed distributions when the sample is large, roughly $n \geq 40$ " (Moore, 2010, p. 458). Sample size for this study well exceeds the minimum guideline of 40 participants.

Table 26.

Number of Items Significantly Different than the Model Mean

\begin{tabular}{lcc}
\hline Board & $\begin{array}{r}\text { Total } \\
\text { Items }\end{array}$ & $\begin{array}{c}\text { \# of items significantly } \\
\text { different than model }\end{array}$ \\
\hline Making Decisions & 13 & 10 \\
Functioning as a Group & 12 & 11 \\
Exercising Authority & 12 & 9 \\
Connecting to the Community & 12 & 6 \\
Working Toward Board Improvement & 12 & 12 \\
Acting Strategically & 12 & 5 \\
\hline
\end{tabular}

Whereas these findings have statistical merit, the researcher also examined differences in scores between each representative role on the board: board member, board president, and school administrator. In so doing, a clearer picture of where the differences actually occur developed. 
To measure these differences between board roles, a one-way Analysis of Variance (ANOVA) was run. Although the research question did not imply a hypothesis directly, the researcher anticipated there would be areas of significant difference since previous board studies (Green and Griesinger, 1996) had found divergence in scores between CEOs and board members. The results of the Christian School board study revealed differences in responses to 10 of the 73 statements. Seven of these items, however, failed Levene's homogeneity of variance test which compares the variances of the samples to ensure they are significantly different. Three responses contained statistically significant differences. One of the items was related to working toward board improvement and the other two were aspects of exercising authority. The following paragraphs explain these differences in greater depth.

Christian School board members have significantly different perceptions regarding how their individual performance is evaluated. Table 27 outlines the one-way ANOVA results comparing the responses of board members, board presidents, and school administrators to the statement "I have never received feedback on my performance as a member of this board."

Table 27.

One-Way ANOVA of Board Member Evaluation by Role $(N=206)$

\begin{tabular}{lllllll}
\hline D. V. & Groups & $S S$ & $d f$ & $M S$ & $F$ & $p$ \\
\hline & & & & & & \\
Feedback on & Between & 20.114 & 2 & 10.057 & $18.836^{*}$ & .000 \\
performance & Within & 69.946 & 131 & .534 & & \\
on the board & Total & 90.060 & 133 & & & \\
\hline
\end{tabular}
$* p<.05$ 
After noting the significance of the ANOVA test, Tukey HSD post-hoc tests were run "to examine the differences between means [to] protect against inflated experimentwise errors" (Runyon, Coleman, and Pittenger, 2000, p. 535). Tukey HSD results revealed the significance to be between school administrators and board members $(p=.000)$ and between school administrators and board presidents $(p=.003)$. These results indicate, not surprisingly, that school administrators feel like their performance is evaluated more than both board presidents and board members. It is unfortunate that only 24.8 percent of board members and 39.1 percent of board presidents receive feedback on their performance. Furthermore, it is startling to think that only two-thirds of administrators $(67.6 \%)$ report having their performance evaluated.

Board members and school administrators also varied significantly in their response to the statement, "Recommendations from the administration are usually accepted with little questioning." Table 28 outlines the one-way ANOVA results comparing the responses of board members, board presidents, and school administrators to this statement.

Table 28.

One-Way ANOVA of Authority-Accepting Administrator's Recommendations by Role $(N=211)$

\begin{tabular}{lllllll}
\hline D. V. & Groups & $S S$ & $d f$ & $M S$ & $F$ & $p$ \\
\cline { 1 - 5 } Authority- & Between & 2.702 & 2 & 1.351 & $3.547^{*}$ & .032 \\
accepting & Within & 49.895 & 131 & .339 & & \\
admin. rec. & Total & 45.701 & 133 & & & \\
\hline
\end{tabular}
$* p<.05$ 
Tukey HSD revealed the significance to be between school administrators and board members $(p=.032)$. This shows that school board members perceive themselves as questioning school administrator recommendations more often than what school administrators believe is the case.

A third statement to which responses were significantly different reads, "The board president and school administrator confer so that differences of opinion are identified." The differences are outlined in the one-way ANOVA table below (See Table 29).

Table 29.

One-Way ANOVA of Authority-President/Administrator Conferring by Role $(N=208)$

\begin{tabular}{lllllll}
\hline D. V. & Groups & $S S$ & $d f$ & $M S$ & $F$ & $p$ \\
\hline & & & & & & \\
Authority- & Between & 4.230 & 2 & 2.115 & $7.161^{*}$ & .001 \\
President/ & Within & 38.695 & 131 & .295 & & \\
admin. confer. Total & 42.925 & 133 & & & \\
\hline
\end{tabular}
$* p<.05$

Tukey HSD revealed the significance to be between board presidents and board members $(p=.001)$ and between board presidents and school administrators $(p=.009)$. Further analysis shows that 100 percent of the board presidents surveyed agreed that they confer with the school administrator whereas 84.2 percent of school administrators agreed that they confer with the board president and 78.9 percent of board members perceive that this communication is happening. 
When scores on each board activity were considered collectively, rather than individually, the ANOVA results indicate significant differences in ratings of school board members compared to presidents and administrators in the area of Working Toward Board Improvement. Table 30 outlines the results of the one-way ANOVA test that was run to see if any of the differences were statistically significant.

Table 30.

One-Way ANOVA of Working toward Board Improvement by Role

\begin{tabular}{lllllll}
\hline D. V. & Groups & $S S$ & $d f$ & $M S$ & $F$ & $p$ \\
\hline Working & Between & 225.623 & 2 & 112.811 & $7.501 *$ & .001 \\
Toward & Within & 1970.079 & 131 & 15.039 & & \\
Board Improv. Total & 2195.701 & 133 & & & \\
\hline$* 0.05$ & & & &
\end{tabular}

The Tukey HSD post-hoc test indicates the significance is between board members and board presidents $(p=.038)$ and between board members and school administrators $(p=$ .003). Thus, both board presidents and school administrators believe their boards to be working toward improvement considerably more than board members do. School administrators perceive this work to be happening at even higher levels than board presidents do.

\section{Gender differences}

Due to the disparity between representation of men and women serving on Christian School boards, $t$ procedures were also used to incorporate gender as an independent variable. Statistically significant difference scores by gender were evident in the areas of working toward board improvement and functioning as a group. Female respondents indicated, at higher levels compared to their male counterparts, that board improvement measures are more observational $(p=.006)$, less formal $(p=.035)$, and lack 
feedback $(p=.011)$. It is apparent, from these data, that women feel more strongly than men that their boards are not taking structured steps toward board improvement.

Ethnicity and race differences

A significant disparity also exists in regard to ethnic and racial diversity of

Christian School boards. Due to the very low number of non-White members, however, $t$ procedures could not be used to incorporate race and ethnicity as a variable in this study.

Question 4-What are Some of the Factors that Predict School Board Effectiveness Ratings?

The researcher planned to conduct an exploratory factor analysis as part of a multiple regression analysis to provide data for the fourth research question. In order to conduct these procedures, sample size is a significant assumption that must be met. "As a general rule of thumb, it is comfortable to have at least 300 cases for factor analysis" (Tabachnick, 2007, p. 613). The final sample size of 217 respondents did not meet the threshold required to conduct a factor analysis. There were, however, significant correlations within the final data set that provide some insight into the relationship between demographic variables and BSAQ ratings.

Board self-assessment questionnaire correlations.

Statistically significant correlations exist between four independent demographic variables and the dependent variable, BSAQ score. Table 31 outlines these correlations. 
Table 31.

Pearson Correlations between Demographic Variables and BSAQ Scores

\begin{tabular}{lrrrrrr}
\hline Variable & Decisions & Group & Authority & Community & Improvement & Strategically \\
\hline Size & -.026 & -.024 & .046 & .056 & $.207 *$ & $.265^{* *}$ \\
Years of service & .102 & .063 & .009 & -.009 & $.348^{* *}$ & .122 \\
Age & .167 & .107 & .116 & .144 & $.232^{* *}$ & $.250^{* *}$ \\
$\begin{array}{l}\text { Board Time } \\
\text { on ProDev }\end{array}$ & .106 & .035 & .158 & .072 & $.205^{*}$ & .131 \\
$\begin{array}{l}* * p<.01 \\
* p<.05\end{array}$ & & & & & &
\end{tabular}

In this table the most interesting relationships are between school size and the perceptions of board members in the areas of working toward board improvement and acting strategically. The larger the school, the more positively board members perceive that their board is working toward board improvement and, even more so, acting strategically. Larger schools do not necessarily have more board members, but they often have multiple school administrators. This being the case, it is possible that boards of larger Christian Schools are more removed from the day-to-day operations of the school and, in turn, act more strategically on longer-term items.

A positive statistically significant correlation $(p=.004)$ was also found between the size of school enrollment and the level of education of the board members. The larger the school, the more years of post-high school education have been completed by school board members. This could be attributed to larger population settings of larger schools where there may be a greater number of jobs that require higher levels of education.

The positive relationship between time spent on professional development and board member's perceptions of working toward board improvement is not surprising. In 
fact, it is encouraging that board members recognize time spent on professional development as an important element in working toward board improvement.

Finally, a positive correlation exists $(p=.045)$ between the percentage of students expected to achieve at or above grade level and the percentage of board meeting time spent discussing the improvement of student achievement. In other words, the more time boards spend discussing student achievement, the higher their expectations for the percentage of students expected to achieve at or above grade level. What is unknown is the direction of this positive relationship; whether high expectations lead to increased time spent discussing student achievement or vice versa.

\section{Open ended question responses}

The majority of open-ended responses related to Smoley's (1999) six themes have been reported earlier in this chapter. Some responses alluded to board members not committing enough time or effort to serve effectively. Other responses referenced how constant board turnover due to short nonrenewable terms has a negative effect on longrange strategic planning. There was also concern voiced regarding long, arduous board meetings that could discourage future candidates from accepting nominations to school board service.

One member noted differences in his/her experience serving on school boards in public and Christian schools. "I have served on the public school board and only a few months on the [Christian School] board. Its as different as night and day." Unfortunately, the person did not elaborate, so the differences cannot be discerned in this study. 


\section{Chapter Five: Discussion}

The purpose of this study was to measure the effectiveness of Christian School boards as perceived by its members. This final chapter outlines the summary of results, theoretical and practical significance, and suggestions for future research.

\section{Summary of Results}

Christian School boards are primarily comprised of well-educated, White, middleaged men from business and/or professional backgrounds. Not only are there a low number of female board members, but there are also no female board presidents or female high school administrators serving on the boards of the 37 schools that chose to participate in this study. Nearly all $(99.1 \%)$ of the members, presidents, and administrators included in this study were White.

The analysis of internal school board activities revealed that Christian School boards perceive themselves to be highly effective at making rational decisions and moderately effective at connecting to the community. Boards are particularly effective in their efforts to reach consensus, act based on shared core values, and respect each other. The data also revealed that, when compared to Smoley's (1999) Model for School Board Effectiveness, Christian School board self-perceptions fell short in the areas of functioning as a group, exercising authority, working toward board improvement, and acting strategically. The difference was strikingly pronounced in the area of working toward board improvement. Professional development activities for Christian School boards are inconsistent and, in many cases, nonexistent. In the area of acting strategically, boards perceived themselves to be inefficient in long-range planning. This is evidenced in board meetings that are dominated by short-term, day-to-day issues. As a whole, 
administrators and board presidents have more positive perceptions about school board effectiveness as compared to the perceptions of board members.

\section{Theoretical Significance}

This study provides the first view behind the closed doors of the Christian School board room. Prior to this study, little was known about the demographic characteristics of Christian School board members. Survey results indicated that they, as compared to their public school counterparts surveyed by Hess (2002), serve shorter terms, are younger, contain a high proportion of males, and are almost exclusively White. Christian School board members, like those in public schools, have a dominant background in the business/professional world and have equivalent levels of education. This demographic information adds to the literature on governing boards because it demonstrates that those serving on Christian School boards are different in a number of ways than those serving on public school boards.

The results of this study also provide new insights into Smoley's (1999) conceptual Model for School Board Effectiveness. Smoley’s (1999) model effectively identifies essential areas of board activity that should be evident on all school boards, public and nonpublic alike. Conversely, there are a few areas of Christian School board activity that the model does not appear to evaluate appropriately.

\section{Making decisions.}

The Model of School Board Effectiveness (Smoley, 1999) adequately assessed how well Christian School boards make decisions, recognizing how well these boards work toward consensus and make decisions that do not result in split-votes. What the model does not appear to take into account, however, is the relationship between reaching 
consensus and working from a base of core values. This relationship is notably stronger in Christian Schools and, in turn, measures of effectiveness must take this into account. Functioning as a group.

The model also works fairly well at measuring how well Christian School boards work together as a group. Results give a clear picture of their ability to act based on shared core values in an environment of trust and respect. Whereas Land (2002) found that many schools struggle to function as a unified body, the focus on core values by boards in this study seems to show that this struggle is less evident in Christian Schools. Unfortunately, the board effectiveness score is lowered when boards strongly disagree that they have acted inconsistently with the school's deepest values. Acting consistently with the school's deepest values should be viewed positively, yet Smoley's (1999) model does not appear to recognize this perspective as a positive element of functioning as a group.

The model also includes an important item regarding how well boards set goals for themselves. Although Christian School boards scored below the model score for this item, the BSAQ does not recognize the centrality of the mission statement as a common goal for Christian School board members. This common mission must be accounted for in order to gain a better picture of how well Christian School boards work together as a group.

\section{Exercising authority.}

Smoley's (1999) model is a good fit for assessing how well Christian School boards exercise appropriate authority. The statements included for this section are appropriate and revealed good areas for Christian School boards to examine. While the 
model is effective, it does not take into account how Christian School administrators serve more with the board than under the board; that is, how nonpublic school governance is "a shared [italics added] organizational process of leadership and policymaking (McCormick, Barnett, Alavi, and Newcombe, 2006, p. 430). Thus the independence of board actions, and the level at which recommendations are questioned, may be examined in a different light when considering the board-administrator relationship in Christian Schools.

\section{Connecting to the community.}

This research using Smoley's (1999) model has revealed that Christian School boards are not as connected to the community as what may have been previously assumed. What the model does not reveal, however, is why this is the case in Christian Schools. Open-ended responses indicated a high level of input from the faculty, staff, and constituency on nearly all the board committees. The BSAQ does not include this level of participation, which could explain why scores were lower in this activity. It would have been expected for this high level of participation to lead to higher scores on connecting to the community; that is, in light of the research by Hofman, Hofman, and Guldemond (2002) that connected high levels of constituent participation to effective boards.

The model is not designed to recognize this level of constituent participation on Christian School boards. Respondents indicated that they do not work with key constituency leaders, yet they do include constituency representatives on board committees. Smoley's model needs to be tweaked to gain a clearer picture of how Christian Schools work with their community. 


\section{Working toward board improvement.}

The Model of School Board Effectiveness is a very good fit for measuring how well Christian School boards work toward board improvement. The results confirm those of prior research (Hekman, 2006; Smoley, 1999; Land, 2002) indicating that boards lack the necessary training to complete the difficult work they face. Smoley's (1999) model shows Christian School boards that they are severely lacking in their work toward board improvement.

Acting strategically.

Christian School board effectiveness in acting strategically is well-measured by The Model of School Board Effectiveness (Smoley, 1999). The lack of attention to longrange planning comes out clearly in the study results. This information provides further insights into what may make Christian School boards different in their strong focus on shorter-term issues. What the model does not explain, however, is how the student achievement in Christian Schools remains very high amidst the short-range work of each school's governing board. Although not confirmed in this study due to areas of misalignment between the Model of School Board Effectiveness and the Christian School board environment, it is likely that student achievement remains high in Christian Schools as a result of the organizational setting in which schooling takes place (Bryk, Lee, and Holland, 1993). This setting includes a close relationship between church, home, and school that work together to help students succeed at the highest levels possible. 


\section{Summary.}

The previous sections show that Smoley's (1999) Model of School Board Effectiveness does, indeed, provide good insights into the work of Christian School boards. On the other hand, results also show that Smoley's (1999) model insufficiently addresses some of the unique features of Christian School board activities. By administering the Christian School board survey with the BSAQ to the entire school board (members, presidents, school administrators), there is now a good foundation of basic information about the work of Christian School boards that was previously unknown. We know that while Christian School boards are severely deficient in the areas of working toward board improvement and focusing on long-range planning, they are exemplary in reaching consensus based on core values and respect. We do not know how the unique relationship between the board and school administrator working with each other, nor how the relationship between the board and the constituency work toward organizational effectiveness of Christian Schools.

\section{Practical Significance}

Many challenges face Christian schools in the $21^{\text {st }}$ century. In order to face these challenges, it is essential for boards to be comprised of the right mix of persons. The demographic information from this study should prod Christian School boards to reexamine their current structure and membership. This examination should lead to analysis of the following seven issues: term length, board size, recruitment, age, gender, race, professional background, and governance style. 


\section{Term length.}

Christian School boards need to examine their current policy on board member term length. The weaknesses in working toward board improvement reported in this study are further exacerbated by the limited terms of Christian School board members. Many of the schools in the survey have three-year, nonrenewable terms for elected board members. Members report learning the ropes the first year, settling in the second year, and finally leading and contributing in the third year. It could be argued that these short board terms make training and mentoring even more important since one-third of board members are new each year.

It could be argued that limited terms bring new faces and broader participation on the board. The lack of experience, however, could weaken the effectiveness of the board as a whole, particularly in the areas of decision making, working as a group, exercising authority, working with the community, working toward board improvement, and acting strategically. Christian School boards need to develop policies that allow members to serve multiple terms.

Christian School boards need to note that for public school board members, 32 states do not impose term limits (NSBA, 2006). It would be helpful for Christian School boards to study the effects of the absence of term limits in public schools and ascertain how the same idea might be effective in Christian School settings. A possible first step would be to extend terms from three years to four years and allow members to serve two consecutive terms. Small measures like extending terms and allowing a one-time renewal of a term may give boards the opportunity to weigh the pros and cons of moving in the 
direction of changing term limits before making more substantive changes such as dropping term limits altogether.

Board size.

Board size is another area of board structure that should be considered. Hess (2002) reported that the majority of public school boards have between five and eight members and less than 20 percent of boards had nine or more members. The Christian School boards in this study ranged in size from five to eighteen members. It is essential for boards to realize that that board size is a factor in a board's performance capacity (Bowen, 2008). It is likely that the size of many Christian School boards were mandated in the school's constitution when the school was founded. It is important for boards to reexamine these mandates to ascertain what size of board is more suitable for the Christian Schools of the $21^{\text {st }}$ century. In recognition of the governance structure of Christian Schools, the need for diversity in board membership, and the need for strong committee leadership, it would seem that Christian School boards need 10 to 12 members for the board, and the organization, to work effectively. For smaller schools in smaller communities, a size of seven to nine members may be more reasonable.

\section{Recruitment.}

A third area in need of examination is the method by which new members are recruited and/or elected. Christian School boards must note that recruiting board members can be challenging. In some cases, anecdotally, current board members have battled unpopularity and ridicule for taking unpopular stances on tough issues. Another issue with recruitment is the overcommitted nature of good leaders. The best leaders are often asked to serve in multiple organizations. This can be particularly challenging in 
Christian Schools where many constituents either serve on the school board or the church consistory. Christian School must work to recruit members who take their calling seriously and who will not accept a position on the board if they do not feel they can devote the time necessary to fulfill their duties completely.

Not only must Christian Schools work to recruit members, they must also open the elections to persons who have the desire and ability to serve. In sum, the nomination process must allow for persons to run for the board on their own volition. Boards must work to allow room for the board itself to continue to approve nominations, but those nominations must include self-nominations. Taking these actions may decrease the number of members who feel obligated to serve and increase the number of those who want to serve. While there may be a fear of politics entering the arena of running for the school board, the possible benefits of having more skilled and committed members could outweigh these concerns. A revised election structure may also allow for great diversity on the board assuming the constituency sees value in diverse representation. On the other hand, it could also present the perception of unofficially earmarking seats for specific areas of diversity.

Age.

Data from the Christian School board survey revealed that Christian Schools have a high percentage of younger members. Christian School boards need to take advantage of the experience that older constituents can bring to the board table. While it is possible that constituents may be burned out of school service by the time they reach their fifties and sixties, it is essential for the whole community to take a deeper look at the responsibility for all ages to serve. 


\section{Gender.}

Christian School boards should have more women members. In many families, it could be argued that women have a better sense of how their children are doing in school and have different ideas about what might be done to remedy issues.

Gender balance could be a little more challenging to handle in some Christian School environments. The strong Christian values in some of the schools included in this study are adamant about the importance of male headship in church and home. This carries over into the school as well. In these more conservative constituencies, it is traditional that women are not asked to serve on Christian School boards. Boards must be sensitive to these views while also reminding constituents that although the church, home, and school work together, each has independent governing structures. Opening the board election structure, as outlined earlier, may create an avenue for women to legitimately earn places on Christian School boards.

Women are not only underrepresented on Christian School boards, but also within the ranks of school administrators. Christian Schools need to look closely at why this is the case and examine strategies to promote gender equity in school leadership, particularly in grades 9-12 and PK-12 positions.

Race.

Results of the Christian School Board Survey reveal disparities in the representation of minorities on the board. It is essential for Christian School boards to work toward a more equivalent representation on the board as compared to the school constituency. Although the racial background of the constituency is unknown, one only needs to enter some of the Christian Schools in this study to see that they no longer serve 
only White families. The lack of racial diversity in school leadership could affect the view of the Christian School from the greater community. The presence of a maledominated, White school leadership team could appear hypocritical when their missions often include reaching out to the community. The actions of the board speak louder than the values and ideals it purports to hold. Boards must work toward greater ethnic diversity at the board level without earmarking positions by encouraging constituents of non-White ethnicity to consider running for the board while still allowing the constituency to have the final vote.

\section{Professional background.}

Boards might also take into consideration the professional background of the members. It is important for membership to include persons from all walks of life as their insights on education come from different angles. It could be interpreted that the high percentage of business and professionals on Christian School boards stems from the belief that these people are already experienced leaders. The Christian School constituency needs to be reminded of scripture's emphasis on all members of the body of Christ working and serving together; that can be extended to say that all members from all walks of life have an important role the work of the Christian School.

\section{Governance structure.}

It is also important for Christian School boards to define who they are and what type of governance best fits their particular situation. While profit and nonprofit boards can learn from each other (Bowen, 2008), board members should take note that what is learned about effective business practices in for-profit boards does not necessarily have a direct relationship with the board activities in nonprofit organizations (Herman and Renz, 
1999). Great care should be taken by Christian School board members and board presidents to understand and differentiate what learned practices can truly be beneficial for their school boards.

Practices from for-profit boards that may help strengthen the work of Christian School boards include more formal proceedings, a greater emphasis on accountability, a regular review of CEO (i.e. school administrator) performance, and a strong focus on strategic planning (Bowen, 2008). Christian School boards may also improve their work by learning more about effective non-profit board practices such as shared governance and efficient resource management (Bowen, 2008).

Not only should Christian Schools reconsider how structure and membership elements should be reflected in their school board, they also need to take a close look at the internal activities of the Christian School board. The activities outlined below are from Smoley's (1999) conceptual Model of School Board Effectiveness that served as the framework for this study.

\section{Making decisions and functioning as a group.}

Christian School board members must work to be in tune with the values of the community. This involves more than simply knowing what the constituency's values are. Board members must move beyond knowledge of community values toward understanding how these values are applied in leadership. Good questions for board members to ask include: Why does a certain value exist? Where did it come from? How long has it been a value of the community? How have the values changed in the past? How are they changing in the present? Answering these questions may assist board members in acquiring a holistic understanding of the culture of the school constituency 
and of how these values can not only inform common group functioning and decision making, but also serve as a foundation for more acting more strategically.

\section{Exercising authority.}

Christian School boards need to make progress is setting goals for the school.

While there is evidence that these boards do well supporting and working with the school administrators, the board itself falls short in being a visionary leader for the school. A clearer understanding of the board authority structure is needed to ensure that members know how to act within defined roles. A first step is for members to recognize the importance of a board president with exemplary leadership skills. Another part requires boards to carefully evaluate the balance between accepting administrator recommendations with little or no questioning and seeking to act independently as a board.

In an effort to improve the effectiveness of their respective school boards, some Christian Schools have adopted the policy governance model of John Carver (2006) which focuses board activity on larger issues, emphasizes delegation of authority, and holds the board accountable for organizational effectiveness. None of these boards, however, have collected any data to evaluate the effect of the Carver model on the board or the school as a whole. Lashway (2002) cautions schools not to expect everything from a model like Carver's (2006) since governance by policy alone is not as easy as Carver suggests, nor does it provide any guarantee of impacting the most important aspect of schooling: student learning. It would be advisable for Christian School boards to recognize that their responsibility is to work through others to create conditions that are ripe for student learning (Rice et al., 2000). 


\section{Working toward board improvement.}

There is considerable room for improvement for Christian School boards in the area of working toward board improvement. One of the areas previously mentioned is improving the recruitment and election of new members. This must be done with care to ensure that the process does not become political. The Christian School constituency must work together to identify and meet the specific needs of board leadership positions and elect persons best suited to address these needs. Boards must also take the time to engage in ongoing self-evaluations of their work. It is not acceptable to blame the lack of evaluation on a lack of time or knowledge.

In the open-ended responses in this study, board members themselves indicate that learning the ropes of Christian School board membership requires a significant amount of time due to the constant turnover of members and the lack of formal training. Boards need to be stronger examples in the area of improvement for the rest of the school to follow as emphasized by Holland and Jackson (1998):

Just as our board members expect staff to show improvements in productivity and gains in impacts, so we [the board] should model the behavior we want from them. Ongoing attention by a board to its own performance leads to a culture of active responsibility for continuous improvement in the quality of its work and greater satisfaction among members. It enables the board to improve its leadership of the organization and demonstrates to others inside and outside how the board expects value to be added to the organization. (p. 133).

As the above quote suggests, Christian School boards must not only take the lead in working toward improvements but should also make sure all members of the organization 
and constituency are aware that these activities are taking place, perhaps via monthly board activity reports to the constituency. The board cannot underestimate its impact on education. Indeed, the tone for the entire school system is set by the board itself.

It is essential for Christian School boards to recognize that the gap between prescription and reality of board practices can be daunting for many board members and, subsequently, the motivation to try to close the gap wanes (Herman, 1989). This lack of motivation and effort means that few members are prepared for the challenges of being a school board member (Holland and Jackson, 1998). Boards must be proactive to seek out assistance for professional development programs. They can begin by using current board leaders, administrators, and fellow members as mentors for one another. They need to attend conferences and work together toward comprehensive improvement initiatives (Eadie, 2007). Christian School boards need to mandate professional development for every member and must provide members with feedback from the board president, school administrator, and other board member peers on each individual member's performance. Acting strategically.

It is quite possible that the lack of effectiveness in acting strategically stems from a type of role reversal. Boards are too involved in management, and administrators are too involved in long-range planning when the opposite should be true. Christian School boards have a tradition of strong communication as borne out in part by this study. There is no excuse for exhibiting ineffectiveness in strategic planning. Christian School boards need to place more trust in school administrators for the day-to-day operations of the school in order to free the board to focus on broader long-term issues. In turn, school 
administrators must take care not to derail the board's long-term work by bringing it into the realm of daily school operations.

Recommendations for Future Research

The exploratory and introductory nature of this study on Christian School board leadership opens many avenues for future research. While there are numerous directions in which future research could improve Christian School board effectiveness, this section will focus on suggested places to begin this journey.

First, future Christian School board research should be extended to include all CSI schools across North America. This would provide a more robust data set and give a clearer picture of the state of Christian School boards. It would also be helpful to study the actions of Christian School boards in other associations such as the Association of Christian Schools International, the National Catholic Educational Association, and the Southern Baptist Association of Christian Schools. Presumably other denominations and/or organizational affiliations share similar connections between church, home, and school as is the case in most CSI schools.

Second, future studies could go beyond board members and school administrators to include constituents as well. Input from constituents would add credence to how satisfied the supporting community is with the school board's governance and provide input on areas of strength and growth. By measuring board effectiveness with input from the constituency, the impact of board activities on overall organizational effectiveness will be more evident.

A third avenue for future research would be to examine the correlations between school size and board effectiveness that were uncovered in this study. More research is 
needed to delve into the strength of these correlations and the relevancy of the information in improving board effectiveness. Boards in larger schools may be more removed from day-to-day operations and, in turn, may have more time and energy to focus on board improvement. Studies of these correlations may help schools of all sizes learn more from each other.

Fourth, it is imperative for future studies to examine the effect of professional development on board effectiveness. Research has shown that the intervention of board training increases scores on the BSAQ (Jackson and Holland, 1998). Similarly, the Christian School board survey revealed a positive correlation between time spent on professional development and the perception of how well boards were working toward improvement. These findings need to be re-tested frequently in a manner that can measure the effect of board training on overall Christian School board effectiveness.

Finally, Christian School boards must take action to evaluate how their work affects student achievement. The absolute number one goal of Christian School boards should be to establish an environment where students are learning how to be transformers of the Creation, to be God's hands and feet in his world. Embedded in this preparation is a focus on high levels of student achievement to perform this calling. At issue, however, is the identification of what student achievement includes in the Christian School. Boards need to work with the administrator and faculty to consider how Christian Schools define student achievement intellectually, spiritually, socially, emotionally, and physically. Christian Schools have the inside track on educating the whole child. It is time for research to more clearly identify what that looks like not only in the classroom, but also on the school board. 
More study is also need needed to learn about the effects of long-range planning on overall organizational effectiveness and student achievement. Survey results indicate a positive correlation between the level of student achievement expected and the amount of time the board spends on decisions directly related to improving student achievement. Standardized test scores show that Christian schools are achieving at some of the highest levels in their respective states. At the same time, as compared to Smoley's (1999) model, the school boards are not as effective as a model board should be. This discrepancy needs a more thorough examination to determine why achievement remains high in these environments.

Model for Christian School Board Effectiveness

Ultimately, a Model for Christian School Board Effectiveness is a natural outgrowth of this study. This model must be designed to measure board effectiveness in light of the unique Christian School environment; a place where faith and learning are a single enterprise. What is unknown, however, is how to measure these factors in such a way that connects school boards and students. Christian School boards are not exemplary in terms of Smoley's (1999) model for board effectiveness, and yet student achievement remains at very high levels. High achievement could be attributed to the close alignment of core values between the school and its supporting constituency. It could be a reflection of parents who are more vested in education as a result of the large amount of tuition dollars paid each year. The homogeneity of the students is another possible factor. In the end, much more research is needed to try to pinpoint what variables have the strongest impact on student achievement in Christian schools. 
A new Model for Christian School Board Effectiveness should move beyond the perceptions of effectiveness to actualities. Qualitative inquiries must be employed to learn more about Christian School board activities. From these inquiries, themes should be extrapolated to provide more insight into how Christian School boards govern and how they can be more effective leaders.

\section{Conclusion}

The school board is central to the success of the school as an organization. This is even more critical in Christian Schools were the connections between church, home, and school are essential for the mission to be fulfilled. Christian School boards, largely unstudied until recently, demonstrate high levels of effectiveness in some areas and yet need considerable assistance in others. Christian School boards can make a difference, but how this best happens is still unclear. More study is needed to explore and investigate the unique aspects of the Christian School board and how operations faithfully uphold the Biblical mission and vision of the constituencies and Lord they serve. A new Model for Christina School Board Effectiveness is needed to help Christian Schools tackle the issues of today and plan for the issues of tomorrow to eternity. 


\section{Appendix A \\ Christian School Board Survey \\ Part I: Demographic Profile}

I. School information

1. Please indicate the name of the school in which you serve (this will be kept completely confidential):

2. Please indicate the city and state where the school is located (this will be kept completely confidential):

3. Please indicate the size of the school:

less than 100
$200-299$
$400-499$

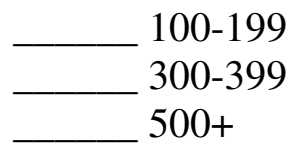

4. Please indicate the setting of your school: Rural/small town $(5,000$ or less) Small city $(5,001-20,000)$ Larger city $(21,000+)$

II. Profile of nonpublic school board members

1. Please indicate your current role on the school board: Board Member Board President School Administrator

2. Please indicate the number of years you have served on the board or as an administrator in this school:

3. Please indicate your age:

\begin{tabular}{lr}
$20-29$ & $30-39$ \\
$40-49$ & $50-59$ \\
\hline 60 or older &
\end{tabular}

4. Please indicate your gender:

Male

5. Please indicate your race:

White

Hispanic
Female

African-American Other 
6. Please indicate your professional background: Business/professional Education Homemaker/retired Other Nonprofit/government

7. Please indicate your highest level of education: Did not graduate from high school High school graduate or GED Some college/post high school training (including a 2-year degree) Four-year college degree Graduate/Advanced Degree

8. Do you currently have children or grandchildren attending this school? Yes No

III. Board service and preparation

1. Please indicate how much time, on average, your board spends in meetings and/or work-sessions each month:

$\begin{array}{lr}0-10 \text { hours } & 11-25 \text { hours } \\ 36-50 \text { hours } & 51-70 \text { hours }\end{array}$

More than 70 hours

2. Please indicate how many hours each month, on average, your board spends on professional development specifically directed to the school board itself:

IV. Board view of student achievement

1. Please indicate your best guess about the percent of students in your school that can be expected to achieve at or above grade level:

2. Please indicate your best guess about the percent of time the board spends discussing improvement in student learning: 


\section{Part II: Board Self Assessment Questionnaire}

Thank you for participating in this self-assessment of your school board. The following statements describe a variety of possible actions by boards. Some of the statements may represent your own experiences as a member of your board, while others may not. For each of the items, there are four possible choices. Please mark the choice which most accurately describes your experience as a member of this board.

There are no "right" or "wrong" answers; your personal views are what is important. In order to ensure the anonymity of all responses, please do not put your name anywhere on the form. Thank you.

Note: This survey was adapted from material originally developed by the Center for Higher Education Governance and Leadership, University of Maryland, College Park, under the funding by the Lilly Endowment. Used by permission of Tom Holland.

\begin{tabular}{|l|l|l|l|l|}
\cline { 2 - 5 } \multicolumn{1}{l|}{} & $\begin{array}{c}\text { Strongly } \\
\text { Agree }\end{array}$ & Agree & Disagree & $\begin{array}{l}\text { Strongly } \\
\text { Disagree }\end{array}$ \\
\hline $\begin{array}{l}\text { 1. This board works to reach consensus on } \\
\text { important matters. }\end{array}$ & & & & \\
\hline $\begin{array}{l}\text { 2. I have participated in board discussions } \\
\text { about what we should do differently as a } \\
\text { result of a mistake the board made. }\end{array}$ & & & & \\
\hline $\begin{array}{l}\text { 3. There have been occasions where the } \\
\text { board itself has acted in ways inconsistent } \\
\text { with the school's deepest values. }\end{array}$ & & & & \\
\hline $\begin{array}{l}\text { 4. This board has formal structures and } \\
\text { procedures for involving the constituency. }\end{array}$ & & & & \\
\hline $\begin{array}{l}\text { 5. I have been in board meetings where it } \\
\text { seemed that the subtleties of the issues we } \\
\text { dealt with escaped the awareness of a } \\
\text { number of the members. }\end{array}$ & & & & \\
\hline $\begin{array}{l}\text { 6. Our board explicitly examines the } \\
\text { "downside" or possible pitfalls of any } \\
\text { important decision it is about to make. }\end{array}$ & & & & \\
\hline $\begin{array}{l}\text { 7. Usually the board and the school } \\
\text { administrator advocate the same actions. }\end{array}$ & & & & \\
\hline $\begin{array}{l}\text { 8. This board is more involved in trying to } \\
\text { put out fires than in preparing for the future. }\end{array}$ & & & & \\
\hline $\begin{array}{l}\text { 9. The board sets clear organizational } \\
\text { priorities for the year ahead. }\end{array}$ & & & & \\
\hline $\begin{array}{l}\text { 10. A written report including the board's } \\
\text { activities is periodically prepared and } \\
\text { distributed to the constituency. }\end{array}$ & & & & \\
\hline
\end{tabular}




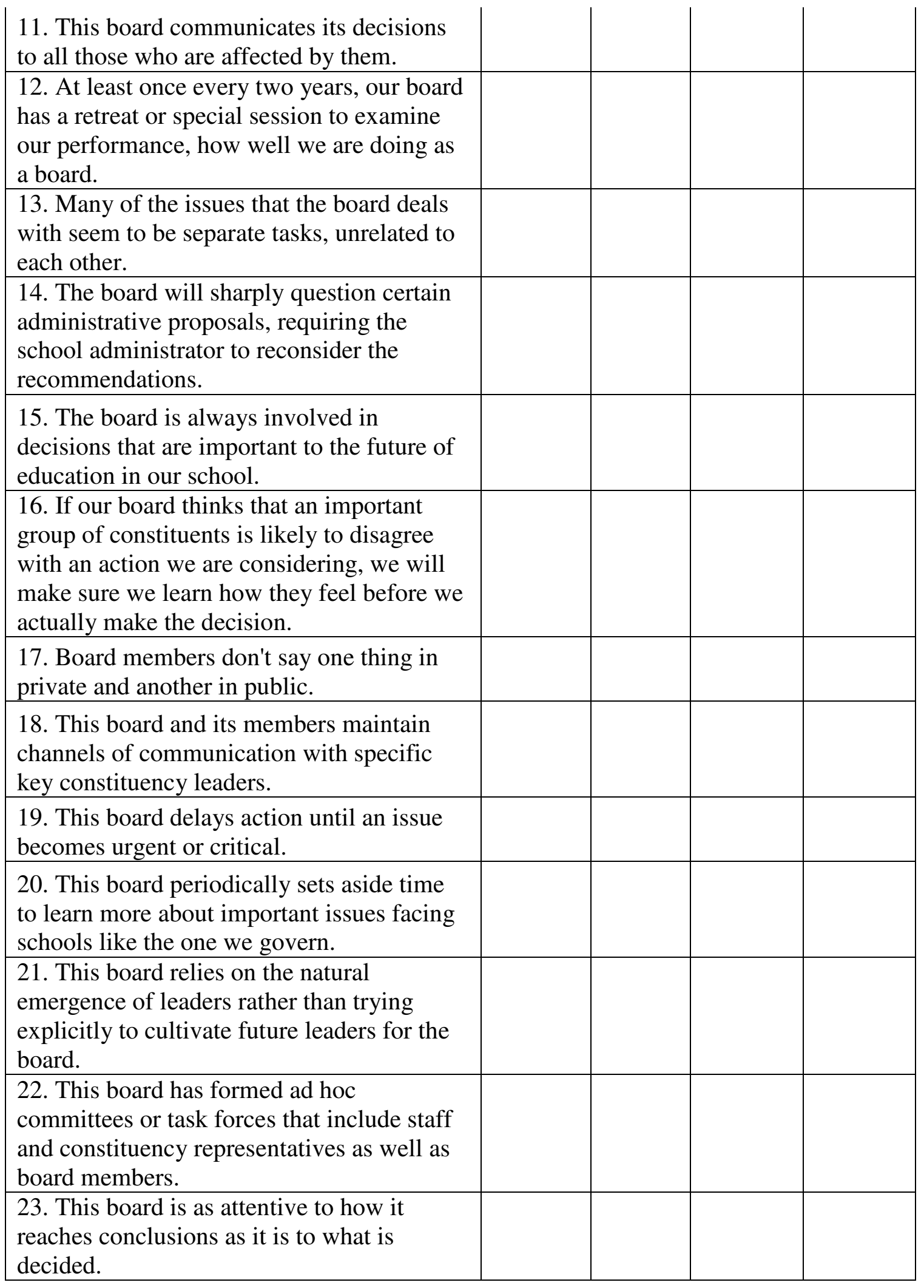









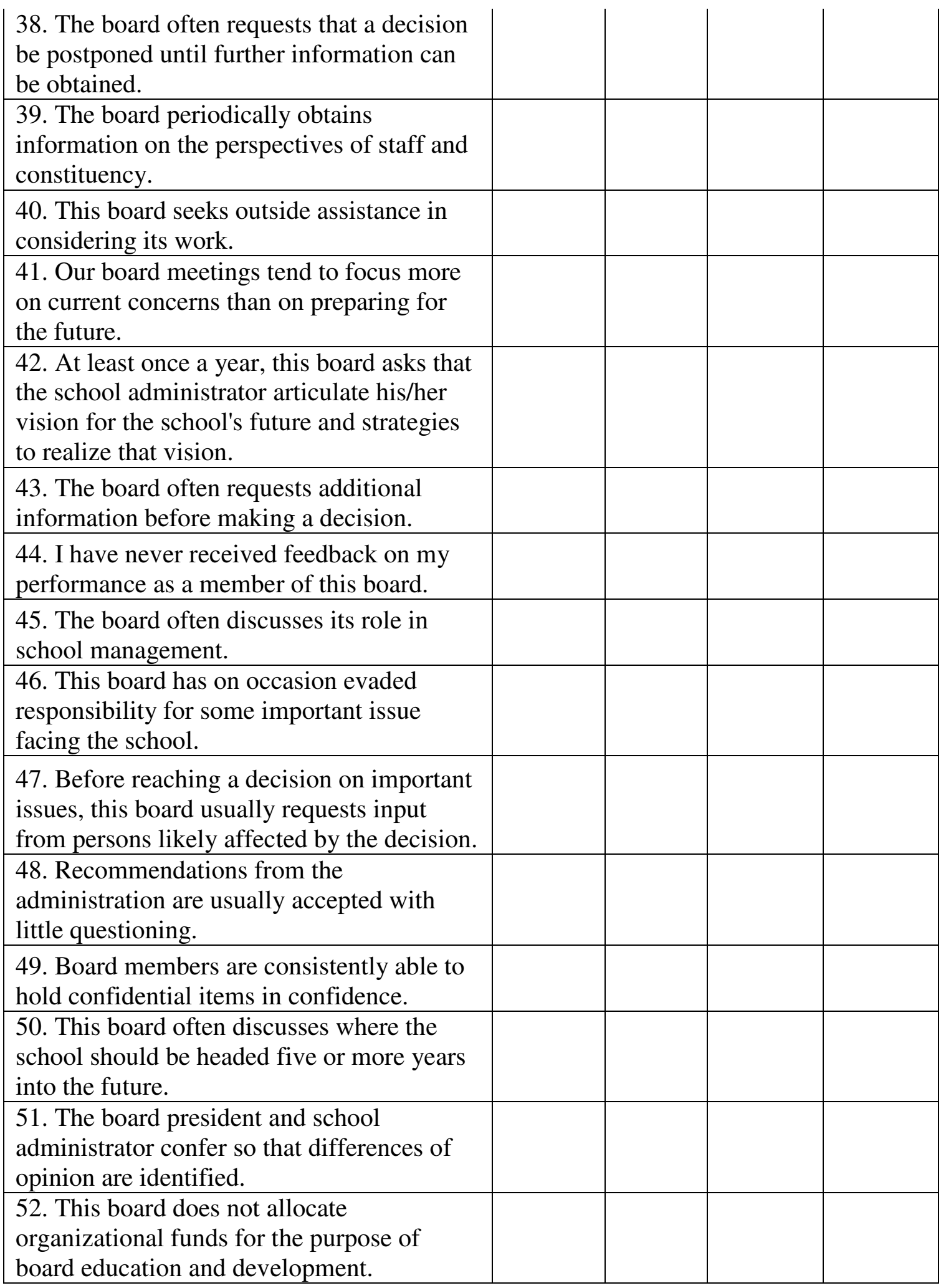




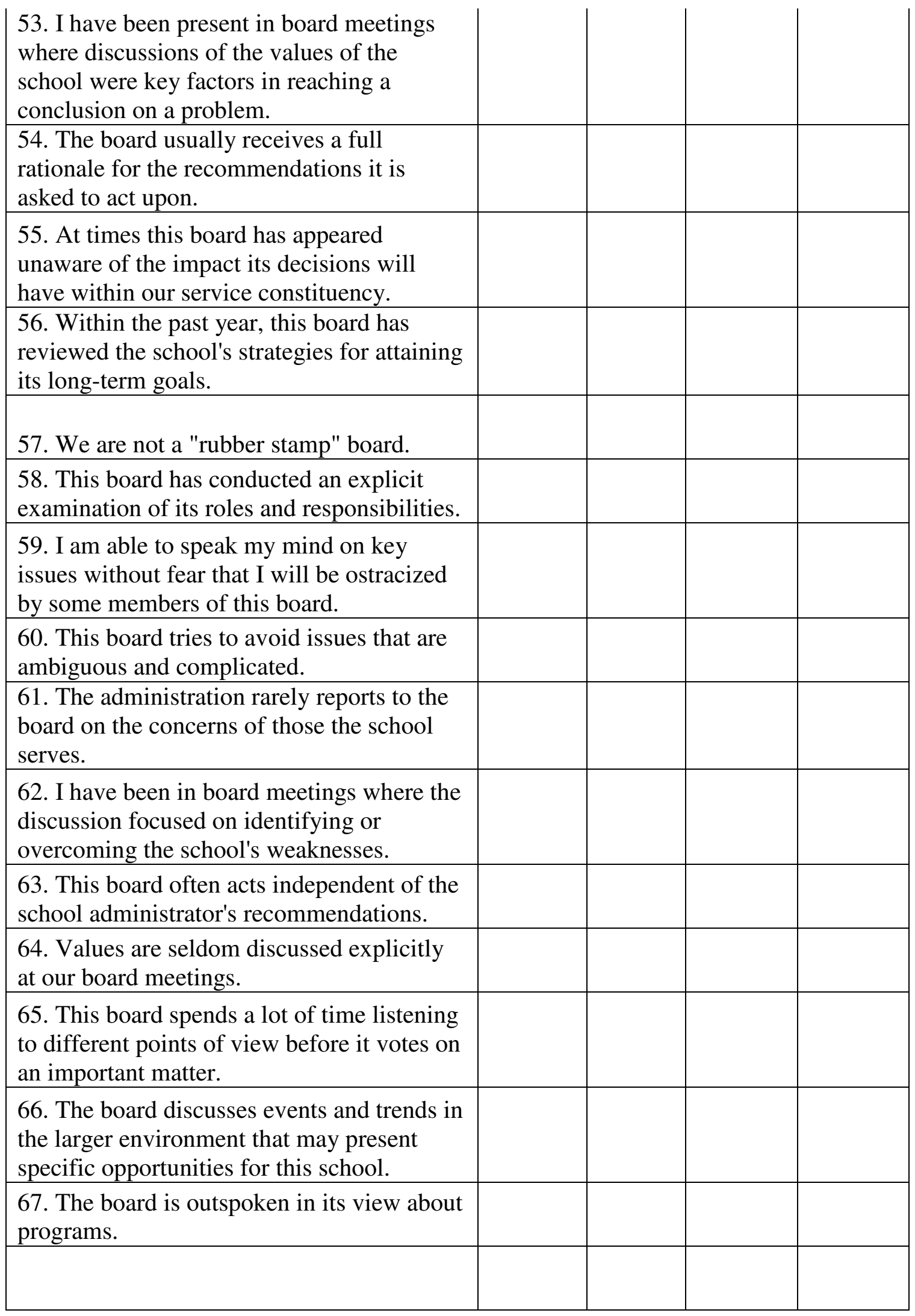


68. Once a decision is made, all board members work together to see that it is accepted and carried out.

69. All board members support majority decisions.

70. This board makes explicit use of the long-range priorities of this school in dealing with current issues.

71. The board will reverse its position based on pressure from the constituency.

72. Members of this board are sometimes disrespectful in their comments to other board members.

73. More than half of this board's time is spent in discussions of issues of importance to the school's long-range future.

\begin{tabular}{|l|l|l|l|l|} 
& & & & \\
& & & & \\
\hline ased & & & & \\
\hline es & & & & \\
\hline is & & & & \\
\hline
\end{tabular}

Is there anything else you would like to share about Christian school board effectiveness? 


\section{Appendix B}

\section{Letter of Invitation/Consent}

\section{[Date]}

Dear Christian School board member,

As a former Christian school principal and teacher in CSI schools, and as a doctoral student at Iowa State University, I am requesting your participation in completing a board governance survey for my dissertation.

This important research project will help Christian school boards better understand their roles and provide school boards with recommended areas of concentration for board development. Your expertise, experience, and commitment to Christian education are highly valued and your responses are need for the success of this project. Christian school boards face many challenges, and this project hopes to assist members in meeting these challenges.

You can access the survey by clicking this link [insert here]. Each and every response is critical for the study to be complete. Respondents and individual schools will not be identified in any way or at any time. Only aggregate data of the groups will be reported.

Your participation in this survey is voluntary. The completion of the survey constitutes your consent to participate. In order to ensure the anonymity of all responses, please do not include your name on any part of the survey.

If you have questions about the study, please contact me at 712-707-7433 or by email at ryan@nwciowa.edu You may also contact my advisor, Dr. Joanne Marshall, Iowa State University, at 515-294-9995 or jmars@iastate.edu with questions concerning the study.

Thank you very much for your participation and your service in Christian education!

In Christ,

Ryan G. Zonnefeld 


\section{Appendix C}

\section{Institutional Review Board Approval for the Study}

\section{IOWA STATE UNIVERSITY \\ OF SCIENCE AND TECHNOLOGY}

DATE:

October 10, 2008

TO:

Ryan G. Zonnefeld

$5261^{\text {st }}$ Avenue SE, Sioux Center, IA 51250

CC:

Joanne Marshall

N229D Lagomarcino

FROM: Jan Canny, IRB Administrator Office of Research Assurances

TITLE:

From Vision to Learning-Effectiveness Measures of Christian School Boards

IRB ID: $\quad 08-300$
Institutional Review Board Office of Research Assurances Vice President for Research 1138 Pearson Hall Ames, lowa 50011-2207 $515294-4566$ FAX $515294-4267$

The Institutional Review Board (IRB) Chair has reviewed the modification of this project and has declared the study remains exempt from the requirements of the human subject protections regulations as described in 45 CFR 46.101(b). The IRB determination of exemption means that:

- You do not need to submit an application for annual continuing review.

- You must carry out the research as proposed in the IRB application, including obtaining and documenting (signed) informed consent if you have stated in your application that you will do so or if required by the IRB.

- Any modification of this research should be submitted to the IRB on a Continuing Review and/or Modification form, prior to making any changes, to determine if the project still meets the Federal criteria for exemption. If it is determined that exemption is no longer warranted, then an IRB proposal will need to be submitted and approved before proceeding with data collection.

Please be sure to use the documents with the IRB approval stamp in your research.

Please note that you must submit all research involving human participants for review by the IRB. Only the IRB may make the determination of exemption, even if you conduct a study in the future that is exactly like this study. 


\section{References}

Allen, A. \& Plank, D. N. (2005). School board election structure and democratic representation. Educational Policy, 19, 510-527.

Alsbury, T. (Ed.). (2008). The future of school board governance: Relevancy and revelation. Lanham, MD: Rowman \& Littlefield.

Archer, J. (2002). Training sessions help urban school boards lead change. Education Week, 21(42), 11.

Besought, P. F. (2002). Rethinking independent school governance. Independent School, 61(4), 7-8

Black, S. (2007, September). Leadership and learning. American School Board Journal, 194(9), 56-59.

Bourque, L. B., \& Fielder, E. P. (2003). How to conduct self-administered and mail surveys. In Arlene Fink (Ed.), The Survey Kit (2nd ed.), Vol. 3. Thousand Oaks, CA: Sage Publishing.

Bowen, W. G. (2008). The board book. New York: W. W. Norton \& Company, Inc.

Boyle, P. (2004). School boards and public values. American School Board Journal, $22-27$.

Bradshaw, P., Murray, V., \& Wolpin, J. (1992). Do nonprofit boards make a difference? An exploration of the relationships among board structure, process, and effectiveness. Nonprofit and Voluntary Sector Quarterly, 21, 227-249.

Bryk, A. S.; Lee, V. E., \& Holland, P B. (1993). Catholic schools and the common good. Cambridge, MA: Harvard University Press. 
Campbell, D. W., \& Greene, D. (1994). Defining the leadership role of school boards in the $21^{\text {st }}$ century. Phi Delta Kappan, 75(5), 391-395.

Carver, J. (2006). Boards that make a difference. San Francisco: John Wiley \& Sons.

Chait, R. P., Holland, T. P., \& Taylor, B. E. (1996). Improving the performance of governing boards. Phoenix, AZ: Oryx Press.

Chalker, D. (November, 1992). Refocusing school leadership for the $21^{\text {st }}$ century across the board. Education Digest, 58(3), 4.

Coleman, M., Isler, B., Bard, J., Zuberbuhler Klaber, K., Bartle, W., Long, N., et al. (2004). Strengthening the work of school boards in Pennsylvania. The Education Policy and Leadership Center K-12 Governance Project.

Conley, D. T. (2003). Who governs our schools?: Changing roles and responsibilities. New York: Teachers College Press.

Cooper, J. (1998). Christian education: The old vision for a new community. Calvin Seminary Forum, 5(3), 4-5.

Cornforth, C. (2001). What makes boards effective? An examination of the relationships between board inputs, structures, processes, and effectiveness in non-profit organizations, 9(3), 217-227.

Creswell, J. W. (2003). Research design: Qualitative, quantitative, and mixed methods approaches (2nd ed.). Thousand Oaks, CA: Sage.

Crotty, M. J. (1998). The foundations of social research. London: Sage Publications.

Czubaj, C. A. (2002). An analysis of school board members. Education, 122(3), 615-617.

Danzberger, J. (1994, January). Governing the nation's schools. Phi Delta Kappan, 75(5), 367. 
Davies, A., Brown, A., Elder, C., Hill, K., Lumley, T., \& McNamara, T. (1999). Dictionary of language testing. Cambridge, UK: Cambridge University Press.

DeKorne, J. (2003, Fall). Core values: an expression of belief. Christian School Administrator, p. 3-4

Eadie, D. (2007, September). How do you manage yourself? American School Board Journal,64-65.

Education: Leaders must be adequately trained. (2008, January 2). The Clarion Ledger. Elve, P. E. (1982). What every Christian school board member should know! Grand Rapids, MI: Christian Schools International.

Epstein, J. L. (Winter, 1985). Home and school connections in schools of the future: Implications of research on parent involvement. Peabody Journal of Education, 62(2), 18-41.

Erickson, D. A. (Ed.). (1969). Public controls for nonpublic schools. Chicago: The University of Chicago Press.

Eskeland, G. S., \& Filmer, D. (2007). Autonomy, participation and learning: Findings from Argentine schools and implications for decentralization. Education Economics, 15(1), 103-127.

Feuerstein, A. \& Dietrich, J. A. (2003). State standards in the local context: A survey of school board members and superintendents. Education Policy, 17(2), 237-256.

Forbes, D. P., \& Millikan, F. J. (2004). Cognition and corporate governance: Understanding boards of directors as strategic decision-making groups. Academy of Management Review, 24(3), 489-505. 
Frankel, M. T. \& Schechtman, J. L. (2006). How to pick good trustees. Independent School, 66(1), 38-47.

Glass, T. E. (2001). Superintendent leaders look at the superintendency, school boards and reform. Denver, CO: Education Commission of the States.

Good, H. (April, 2007). Leader of the pack. American School Board Journal, 50-51.

Goodman, R. H., Fulbright, L., \& Zimmerman, W. G. (1997). Getting there from here: School board-superintendent collaboration: Creating a school governance team capable of raising student achievement. Arlington, VA: Educational Research Service \& New England school Development Council.

Haan, S. D. (Ed.). (1993). From vision to action: The basis and purpose of Christian schools. Grand Rapids, MI: Christian Schools International.

Hekman, B. (2006). Deep change or slow death. Christian School Administrator, 14(1), 1-4.

Herman, R. D. (1989). Concluding thoughts on closing the board gap, in Herman, R. and Van Til, J. (eds) Nonprofit Boards of Directors: Analyses and Applications. New Brunswick: Transaction Books.

Herman, R. D., \& Renz, D. O. (1997). Board practices of especially effective and less effective local nonprofit organizations. Paper presented at the 1997 annual meeting of the Association for Research on Nonprofit Organizations and Voluntary Action, Indianapolis, IN.

Herman, R. D., \& Renz, D. O. (1999). Theses on non profit organizational effectiveness. Nonprofit and Voluntary Sector Quarterly, 28(2), 107-126. 
Hess, F. M. (2002). School boards at the dawn of the $21^{\text {st }}$ century: Conditions and challenges of district governance. Alexandria, VA: National School Boards Association.

Hofman, R. H., Hofman, W. H. A., \& Guldemond, H (1999). Social and cognitive outcomes: A comparison of contexts in learning. School Effectiveness and School Improvement, 10(3), 352-366.

Hofman, R. H., Hofman, W. H. A., \& Guldemond, H. (2002). School governance, culture, and student achievement. International Journal of Leadership in Education, 5(3), 249-272.

Holland, T. P., Chait, R. P. \& Taylor, B. E. (1989). Board effectiveness: Indentifying and measuring trustee competencies. Research in Higher Education, 30(4), 435-453.

Holland, T. P., \& Jackson, D. K. (Winter, 1998). Strengthening board performance: Findings and lessons from demonstration projects. Nonprofit Management \& Leadership, 9(2), 121-134.

Hopkins, M. M., O’Neil, D. A., \& Williams, H. W. (2007). Emotional intelligence and board governance: Leadership lessons from the public sector. Journal of Managerial Psychology, 22(7), 683-700.

Hunt, J. \& Blanchard, S. (1990). Decades of destiny for school boards. Clearing House, 64(1), 49-50

Illman, B. (n. d.). Why we are the way we are-A defense of covenantal Christian education. Christian School Administrator.

Jackson, D. K., \& Holland, T. P. (1998) Measuring the effectiveness of nonprofit boards. Nonprofit and Voluntary Sector Quarterly, 27 (2), 159-182. 
Kirst, M. W. (1994). A changing context means school board reform. Phi Delta Kappan, 75(5), 378-381.

Land, D. (2002). Local school boards under review: Their role and effectiveness in relation to students' academic achievement. Review of Educational Research, 72(2), 229-278.

LaRocque, L., \& Coleman, P. (1993). The politics of excellence: Trustee leadership and school district ethos. The Alberta Journal of Educational Research, 39(4), $449-475$.

Lashway, L. (2002). Using school board policy to improve student achievement (Report No. ED472183 2002-12-00). Eugene, OR: ERIC Clearinghouse on Educational Management. (ERIC Document Reproduction Service No. ED472183).

Lister, G. (January, 2007). 7 tips for effective boardsmanship. American School Board Journal, 44-45.

Manley, R. J. (September, 2005). A tune-up toolkit for boards. American School Board Journal, 64-65.

McCormick, J., Barnett, K., Alavi, S. B., \& Newcombe, G. (2006). Board governance of independent schools. Journal of Educational Administration, 44(5), 429-445.

McMillan, J. H., \& Schumacher, S. (2006). Research in education: Evidence-based inquiry. Boston: Pearson Education.

Mid-continent research for Education and Learning (McREL). (September, 2006). School district leadership that works: the effect of superintendent leadership on student achievement. (A Working Paper). Denver, CO: Waters, J. T. \& Marzano, R. J. 
Moore, D. S. (2010). The basic practice of statistics.

New York: W.H. Freeman and Company.

Mountford, M. (2004). Motives and power of school board members: Implications for school board-superintendent relationships. Educational Administration Quarterly, 40, 704-741.

National School Boards Association (NSBA). (2006, October). Survey of the state school board associations on term limits for local board members. Arlington, VA.

National School Boards Association (NSBA). (2008, September). Mandated training for local school board members survey. Arlington, VA.

Nederhood, J. (1990). Education and God, the Bible, and Jesus Christ. The Radio Pulpit, $36(9)$.

Opfer, V. D. (2001). Sorting out a sense of place: School and school board relationships in the midst of school-based decision making. Peabody Journal of Education, 76(2), 101-118.

Paige, R. (2002). School boards: Holding the power and bearing the responsibility for educational leadership. Paper presented at the National School Boards Association Annual Conference - The Second Annual Jacqueline P. Danzberger Memorial Lecture, New Orleans, Louisiana.

Petronis, J., et al. (1996). Mandatory school board training: An idea whose time has come? (Technical Research Report \#143). Macomb, IL: Western Illinois University. 
Rice, R., Delagardelle, M., Buckton, M. Jons, C., Lueders, W., Vens, M. J., et al. (2000). The Lighthouse Inquiry: School Board/Superintendent Team Behaviors in School Districts with Extreme Differences in Student Achievement. Des Moines, IA: Iowa Association of School Boards.

Runyon, R. P., Coleman, K. A., \& Pittenger, D. J. (2000). Fundamentals of behavioral statistics $\left(9^{\text {th }}\right.$ ed.). Boston: McGraw Hill.

Shields, P. \& Tajalli, H. (2006). Intermediate theory: The missing link in successful student scholarship. Journal of Public Affairs Education, 12 (3), 313-334.

Smoley, E. R. (1999). Effective school boards: Strategies for improving board performance. San Francisco: Josey-Bass Inc.

Tabachnick, B. G., \& Fidell, L. S. (2007). Using multivariate statistics (5th ed.). Boston: Pearson Education, Inc.

Vander Ark, D. (n. d.). Covenant, kingdom, and mission: Bedrocks for Christian schools. Christian School Administrator.

Van Dyk, J. (1985). The beginning of wisdom: The nature and task of the Christian School. Grand Rapids, MI: Christian Schools International.

Wong, K. K. (1995). Toward redesigning school board governance. Teachers College Record 96(3), 569-576.

Woodward, C. L. (2006). Effectiveness of governance boards in traditional public school districts and community public schools in Ohio. Unpublished doctoral dissertation, Bowling Green State University.

Zwaanstra, H. (1998). Christian education in the Christian Reformed Church. Calvin Seminary Forum, 5(3), 3. 
Zylstra, C. E. (1999, Summer). On being reformed. Dordt College Voice, p.2. 


\section{Acknowledgments}

Thank you to....

...Northwestern College for its support in this endeavor

...Joanne Marshall, and the members of my doctoral program of study committee:

Mike Book, Larry Ebbers, James Scharff, and Jan Westerman-Beatty for their encouragement and support

...Mary Delagardelle for giving me a home away from home during my doctoral work and helping me get connected to the school board research community

...Brittany Lassen, my work study student, for her assistance with multiple facets of this study

...my friends who have been supportive and encouraging at all times

...my extended family who have been supportive through meals, childcare, chauffeuring, and many other unheralded tasks

...the Christian School board members who took the time to participate in this study and who are dedicated to be God's instrument in shaping young lives 